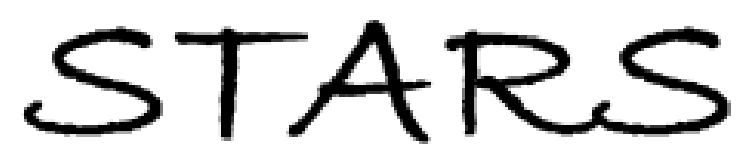

University of Central Florida

STARS

2014

\title{
Dishwashing Water Recycling System and Related Water Quality Standards for Military Use
}

Jared Church

University of Central Florida

\section{Part of the Environmental Engineering Commons}

Find similar works at: https://stars.library.ucf.edu/etd

University of Central Florida Libraries http://library.ucf.edu

This Masters Thesis (Open Access) is brought to you for free and open access by STARS. It has been accepted for inclusion in Electronic Theses and Dissertations, 2004-2019 by an authorized administrator of STARS. For more information, please contact STARS@ucf.edu.

\section{STARS Citation}

Church, Jared, "Dishwashing Water Recycling System and Related Water Quality Standards for Military Use" (2014). Electronic Theses and Dissertations, 2004-2019. 655.

https://stars.library.ucf.edu/etd/655

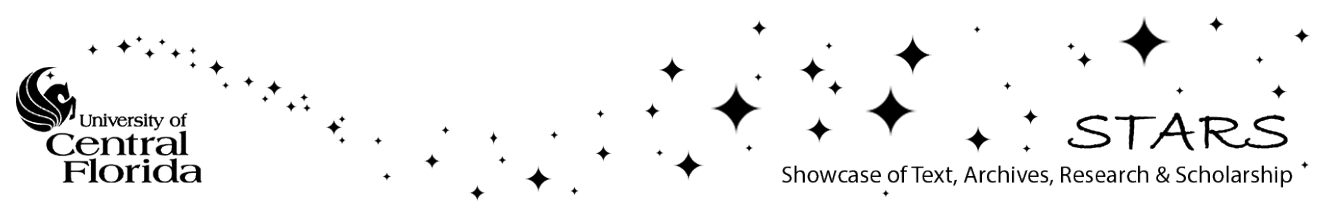




\title{
DISHWASHING WATER RECYCLING SYSTEM AND RELATED WATER QUALITY STANDARDS FOR MILITARY USE
}

\author{
by \\ JARED KYLE CHURCH \\ B.A. University of South Florida, 2012

\begin{abstract}
A thesis submitted in partial fulfillment of the requirements for the degree of Master of Science in the Department of Civil, Environmental, and Construction Engineering in the College of Engineering and Computer Science at the University of Central Florida Orlando, Florida
\end{abstract}

\section{Summer Term}

2015

Major Professor: Woo Hyoung Lee 
(C) 2015 Jared Church 


\begin{abstract}
As the demand for reliable and safe water supplies increases, both water quality and available quantity are being challenged by population growth and climate change. Greywater reuse is becoming a common practice worldwide; however, in remote locations of limited water supply, such as those encountered in military installations, it is desirable to expand its classification to include dishwashing water to maximize the conservation of fresh water. Given that no standards for dishwashing greywater reuse by the military are currently available, the current study determined a specific set of water quality standards for dishwater recycling systems for U.S military field operations.
\end{abstract}

A tentative water reuse standard for dishwashing water was developed based on federal and state regulations and guidelines for non-potable water, and the developed standard was cross-evaluated by monitoring water quality data from a full-scale dishwashing water recycling system using an innovative electrocoagulation and ultrafiltration process. A quantitative microbial risk assessment (QMRA) was also performed based on exposure scenarios derived from literature data. As a result, a specific set of dishwashing water reuse standards for field analysis (simple, but accurate) was finalized as follows: turbidity ( $<1 \mathrm{NTU})$, E. coli $\left(<50 \mathrm{cfu} \mathrm{mL}^{-}\right.$ ${ }^{1}$ ), and $\mathrm{pH}(6-9) . \mathrm{UV}_{254}$ was recommended as a surrogate for organic contaminants (e.g., BOD5), but requires further calibration steps for validation.

The developed specific water standard is the first for dishwashing water reuse and will be expected to ensure that water quality is safe for field operations, but not so stringent that design complexity, cost, and operational and maintenance requirements will not be feasible for field use. In addition the parameters can be monitored using simple equipment in a field setting with only 
modest training requirements and real-time or rapid sample turn-around. This standard may prove useful in future development of civilian guidelines. 


\section{ACKNOWLEDGMENTS}

I thank all who contributed in the completion of this thesis in one way or another. First, I would like to give thanks to God without whom nothing is possible.

I am so grateful for my advisor, Dr. Woo Hyoung Lee, who guided me with understanding and generous guidance and support. With his ambitious attitude, I was able to immerse myself in a broad range of research involvement. I would also like to thank my master thesis committee, Dr. Andrew Randall and Dr. Steven Duranceau for their guidance and encouragement during this work.

I express deep gratitude to Mainstream Engineering Corporation for funding this research. I especially thank Ted Amundson, Dustin Zastrow and Joseph Dixon for their cooperation and support.

I express my thanks to Maria Real-Robert for her guidance in the lab, from whom I learned the analytic techniques needed for the completion of this research, and to Matt Verbyla for his expertise on QMRA. His determination and professionalism was deeply appreciated. I would also like to thank my research group friends: Xiangmeng Ma, Faris Munshi and Xiaochen Wang for their help with laboratory work and support.

Finally, I dedicate this work to my wife, Haillie, for her devotion and endless support. I thank my parents and family and parents-in-law and their family members for their love, support and endless encouragement. 


\section{TABLE OF CONTENTS}

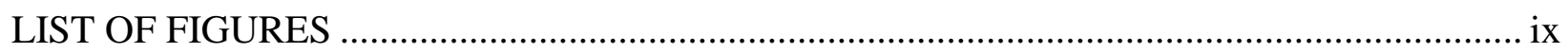

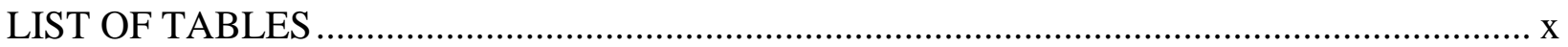

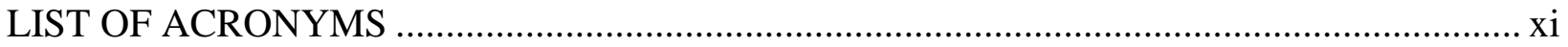

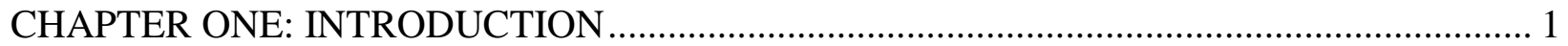

CHAPTER TWO: DEVELOPMENT OF INTIAL WATER QUALITY STANDARDS FOR

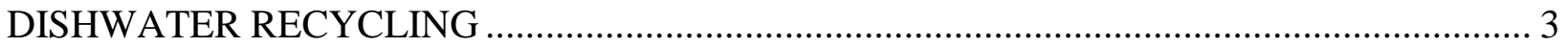

2.1 Water Reuse Regulations, Guidelines and Applications ............................................. 3

2.2 Greywater Regulations and Guidelines in the United States ...................................... 6

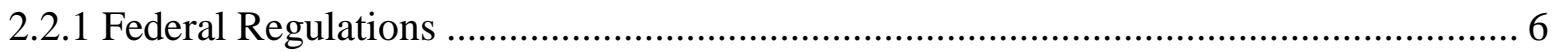

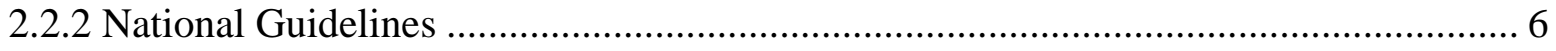

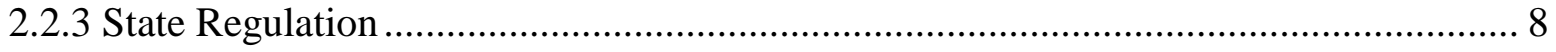

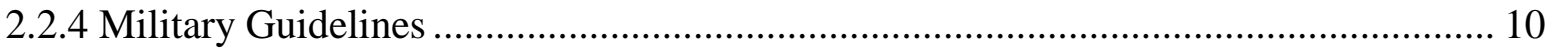

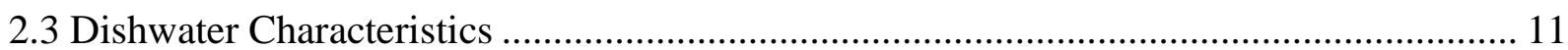

2.4 Health Concerns Associated with Dishwater............................................................ 12

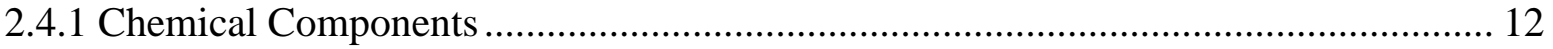

2.4.2 Microbiological Components......................................................................... 14

2.5 Parameters for Water Quality Standards ......................................................... 15

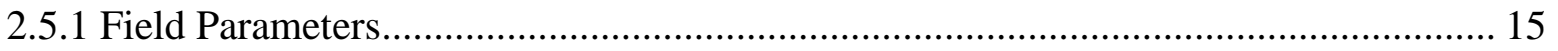

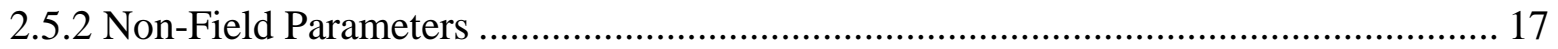


2.6 Initial Water Quality Standards for Dishwater Reuse.

CHAPTER THREE: EVALUATION OF A DISHWASHING WATER RECYCLING SYSTEM

3.1 Dishwashing Water Recycling System ............................................................. 22

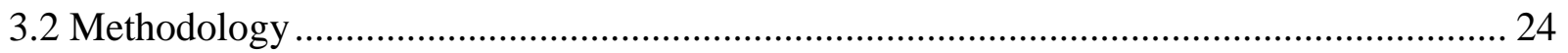

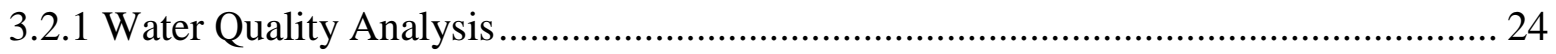

3.2.2 Potential Microbial Growth: The Effect of Surfactant and Ultrafiltration Treatment of

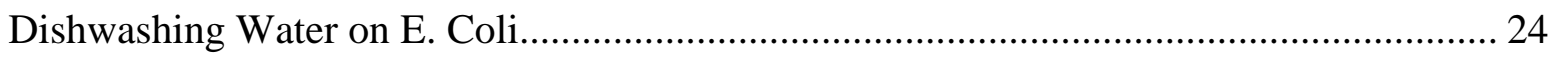

3.2.3 Chlorine Demand and Disinfection by-Product Formation Potential (DBFP) of Treated

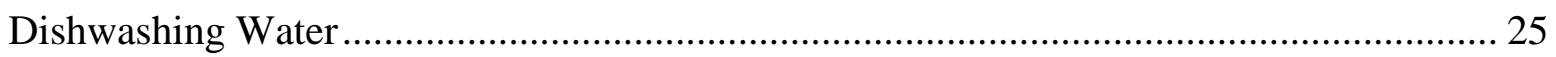

3.2.4 Quantitative Microbial Risk Assessment (QMRA) .......................................... 26

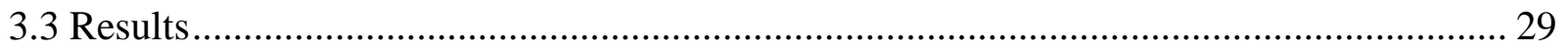

3.3.1 Effluent Water Characteristics ...................................................................... 29

3.3.2 Chlorine Demands and the Formation of Disinfection by-Products......................... 30

3.3.3 Effects of Surfactants of Microbial Growth....................................................... 34

3.3.4 Quantitative Microbial Risk Assessment ........................................................ 35

CHAPTER FOUR: DEVELOPMENT OF DISHWATER RECYCLING STANDARDS ......... 38

4.1 Recommended Water Quality Standards for Dishwashing Water Recycling .................. 38

4.2 Environmental Discharge Considerations............................................................. 40

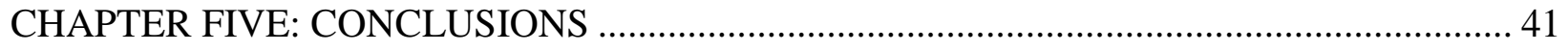

APPENDIX A: DETERGENT ANALYSIS ................................................................. 42 
APPENDIX B: ADDITIONAL WATER REUSE STANDARDS ...................................... 45

APPENDIX C: THM ANALYSIS QUALITY ASSURANCE/QUALITY CONTROL ............. 48

APPENDIX D: ADVANCED ENVIRONMENTAL LABORATORIES' HAA REPORT ........ 51

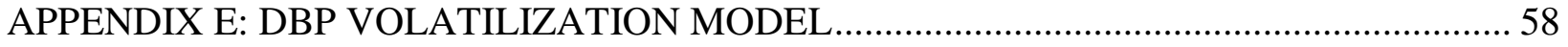

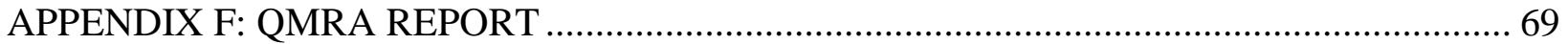

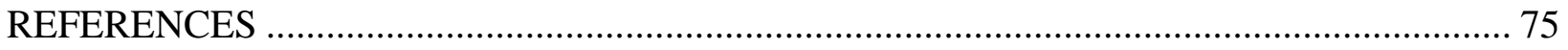




\section{LIST OF FIGURES}

Figure 1. Guidelines, regulations and applications of greywater reuse. ................................... 3

Figure 2. Schematic diagram of a greywater recycling process for dishwashing water............. 23

Figure 3. Chlorine demands for treated dishwashing water $(\mathrm{pH} 9.5)$ at $32^{\circ} \mathrm{C}$ with chlorine doses

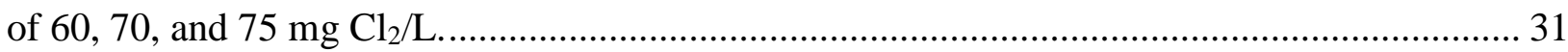

Figure 4. Effect of surfactants on E. coli decay........................................................... 35

Figure 5. Maximum tolerable concentration of reference pathogens vs. volume of recycled dishwater ingested (accidentally or intentionally) per person per day, based on a limit of one

illness per 50,000 exposures, assuming that exposure occurs daily.................................... 36 


\section{LIST OF TABLES}

Table 1. A selection of greywater reuse standards, guidelines and regulations from around the

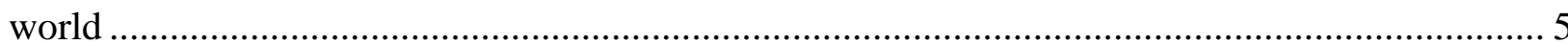

Table 2. EPA guidelines for water reuse (2012): unrestricted urban reuse .............................. 7

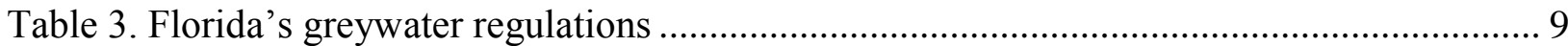

Table 4. U.S. military showering water standards ..................................................... 10

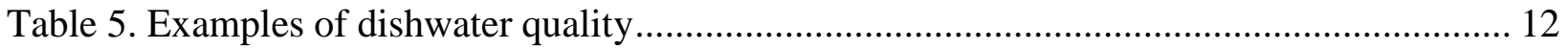

Table 6. QMRA model parameter assumptions.............................................................. 28

Table 7. Developed dishwashing water recycling system effluent characteristics .................... 29

Table 8. THM and HAA formation potential of UF/EC treated dishwater .............................. 33

Table 9. Developed water quality standard of the dishwashing water recycling system for

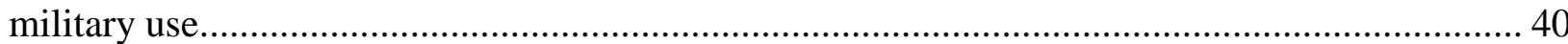




\section{LIST OF ACRONYMS}

\begin{tabular}{|c|c|}
\hline ANSI & American National Standards Institute \\
\hline BOD & biochemical oxygen demand \\
\hline CBOD & carbonaceous biochemical oxygen demand \\
\hline CFU & colony forming unit \\
\hline COD & chemical oxygen demand \\
\hline CWA & Clean Water Act \\
\hline DALY & disability adjusted life years \\
\hline DBP & disinfection by-product \\
\hline DBPFP & disinfection by-product formation potential \\
\hline DBAA & dibromoacetic acid \\
\hline DCAA & dichloroacetic acid \\
\hline DO & dissolved oxygen \\
\hline DOC & dissolved organic carbon \\
\hline DPR & direct potable reuse \\
\hline EDC & endocrine disrupting compounds \\
\hline USEPA & U.S. Environmental Protection Agency \\
\hline FAC & Free available chlorine \\
\hline $\mathrm{FC}$ & Fecal Coliform \\
\hline FOB & forward operating base \\
\hline FSIS & U.S. Food Safety and Inspection Service \\
\hline FDEP & Florida Department of Environmental Protection \\
\hline
\end{tabular}




\begin{tabular}{|c|c|}
\hline HAA & haloacetic acids \\
\hline IPC & International Plumbing Code \\
\hline IPR & indirect potable reuse \\
\hline MBAA & monobromoactic acid \\
\hline MCAA & monochloroacetic acid \\
\hline MCL & maximum contaminant level \\
\hline MDGs & Millennium Declaration Goals \\
\hline MPN & most probable number \\
\hline NDMA & N-nitrosodimethylamine \\
\hline NOM & natural organic matter \\
\hline NPDES & National Pollutant Discharge Elimination System \\
\hline NSF & National Sanitation Foundation \\
\hline NTU & nephelometric turbidity unit \\
\hline O\&G & Oil and Grease \\
\hline OSHA & U.S. Occupation Safety \& Health Administration \\
\hline QMRA & quantitative microbial risk assessment \\
\hline SDWA & Safe Drinking Water Act \\
\hline SUVA & specific ultraviolet absorbance \\
\hline TB MED & Technical Bulletin Medical \\
\hline TCAA & trichloroacetic acid \\
\hline TDS & total dissolved solids \\
\hline THM & trihalomethanes \\
\hline
\end{tabular}




$\begin{array}{ll}\text { TOC } & \text { total organic carbon } \\ \text { TP } & \text { total phosphorus } \\ \text { TSS } & \text { total suspended solids } \\ \text { UF } & \text { ultrafiltration } \\ \text { UPC } & \text { Uniform Plumbing Code } \\ \text { USACE } & \text { U.S. Army Corps of Engineers } \\ \text { USAPHC } & \text { U.S. Army Public Health Command } \\ \text { WHO } & \text { World Health Organization }\end{array}$




\section{CHAPTER ONE: INTRODUCTION}

The demand for reliable and safe water supplies for municipal, agricultural, industrial, and military use has been continuously growing over the last few decades with population growth, economic development, climate change, and depletion of traditional freshwater supplies (USEPA 2012). Greywater is spent water from bathroom and kitchen sinks, showers/bathtubs, and laundry facilities (Scholze and Page 2011) and is typically reused as irrigation and cooling water in urban settings. Greywater reuse has attracted plenty of attention as a water conservation strategy and many greywater reuse systems have been developed and implemented in commercial and residential facilities to achieve significant water savings indoors and outdoors (Yu et al. 2013). However, in remote locations of limited water supply, like those encountered in military installations, greywater applications are expanded to showering and firefighting. For these remote places, it is desirable to expand potential uses to include the recycle of dishwashing water to maximize the conservation of fresh water.

This thesis sought to develop a specific water reuse standard for a dishwashing water recycling system for military field operations in fresh water-limited locations and to validate the developed water standard by cross-evaluating the water quality data from a greywater recycling system. For the current scope of work, this study focused on water reuse within the United States (U.S.) military; however, the results of this study may be applicable for a number of other settings involving traveling individuals in remote and water-scarce locations, such as Peace Corps volunteers.

For the reuse of greywater in the U.S., many regulations and standards have been developed based on the U.S. Environmental Protection Agency (USEPA) Secondary Treatment 
Standard. Water quality standards for greywater reuse should satisfy the following four criteria: hygienic safety, aesthetics, environmental tolerance, and economic feasibility (Nolde 2000). Typical greywater standards are regulated at the state level and exclude greywater generated from dishwashing because of the relatively large concentration of pollutants (USEPA 2012; Friedler 2004; Li et al. 2009). However, these standards vary from state to state and there are currently no guidelines or regulations regarding dishwashing water reuse at either the federal or state level or in the U.S. Army Public Health Command (USAPHC) guidelines (USAPHC 2011). Guidelines for water reuse in military field operations set by U.S. Army Technical Bulletin (TB) MED 577: "Sanitary Control and Surveillance of Field Water Supplies" differ from stateregulated standards and include standards for shower and laundry water recycling (US Army 2010); but there are no standards for dishwater recycling. The gap between state greywater regulations and military guidelines, along with the lack of guidelines for dishwater reuse standards make the deployment of a dishwater recycling system difficult (Lazarova et al. 2003).

Given the need to further develop military guidelines for dishwater recycling, the objective of this thesis is to recommend standards for the use of reclaimed dishwashing water, based on federal, state, and USAPHC regulations and guidelines for non-potable water use. Various water quality data (e.g., BOD, COD, TOC, pH, Turbidity, TSS, TDS, TP, UV 254 , and SUVA), along with chlorine demand and disinfection by-product formation potential, were assessed using a full-scale dishwashing water recycling system with electrocoagulation (EC) and ultrafiltration (UF). A quantitative microbial risk assessment (QMRA) model was used to develop recommendations for the maximum tolerable concentrations of E. coli, Salmonella, and human norovirus in reclaimed dishwashing water. 


\section{CHAPTER TWO: DEVELOPMENT OF INTIAL WATER QUALITY STANDARDS FOR DISHWATER RECYCLING}

\section{$\underline{\text { 2.1 Water Reuse Regulations, Guidelines and Applications }}$}

As natural water sources become strained from population growth, water utilities have been looking to reduce freshwater demands through the reuse of greywater for non-potable uses (USEPA 2012). The most common practice for water reuse is agricultural irrigation (WHO 2006). However, the applications also include industrial, environmental, and urban reuse.

Greywater constitutes almost $70 \%$ of all domestic wastewater, but only contains $30 \%$ of the organic pollutants making it a common source for water reuse (Pidou et al. 2007). Currently, regulations controlling the quality of treated and/or untreated water for reuse are only controlled at the state or local level (Figure 1).

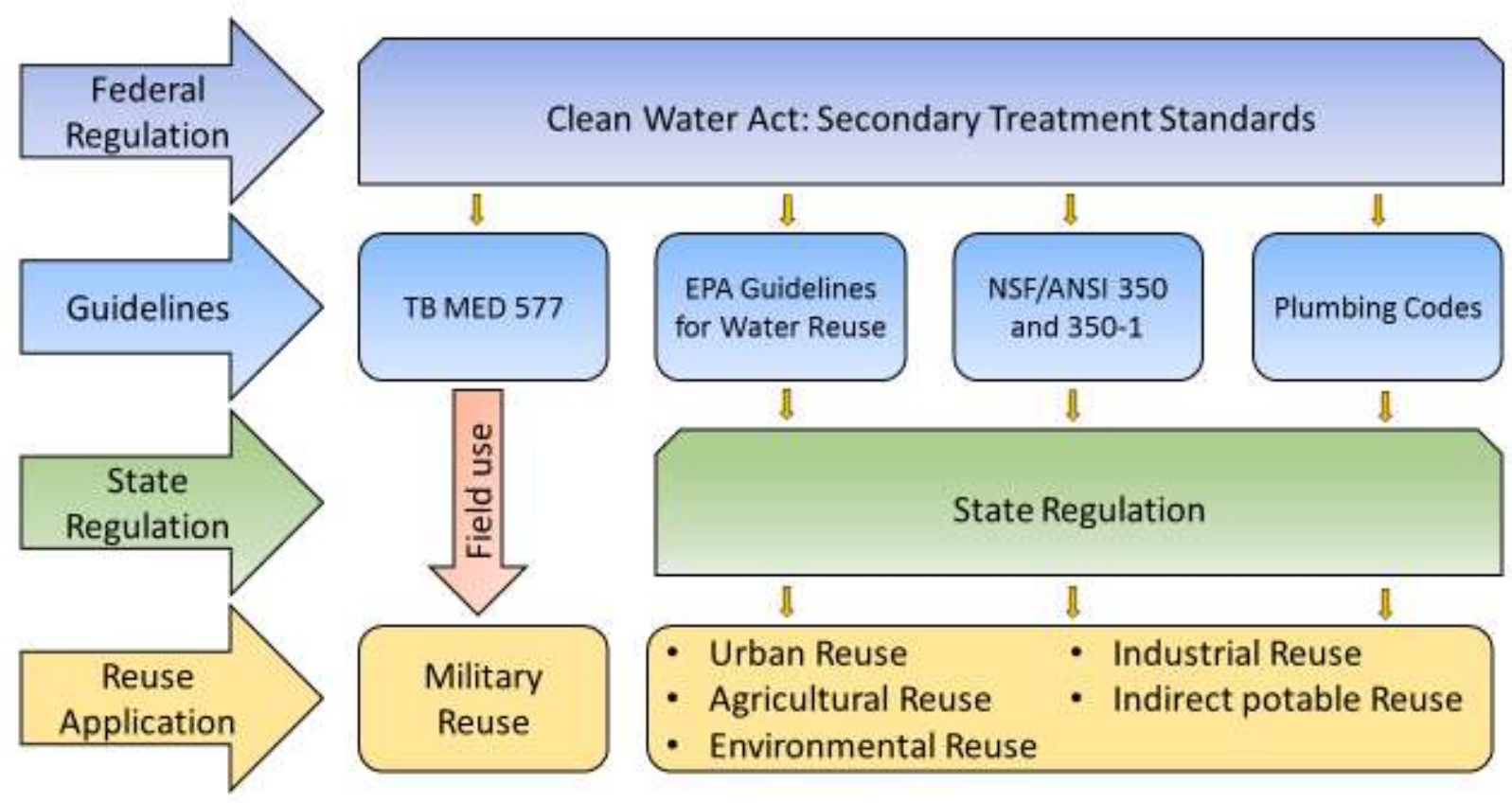

Figure 1. Guidelines, regulations and applications of greywater reuse. 
The state of California was the first to generate water reuse standards for irrigation in 1918 and as interest continued to increase, the U.S. EPA drafted guidelines to offer support to states who wished to develop their own regulation (USEPA 2012). Today, more than 30 states have some form of legislation governing water reuse (Yu et al. 2013). As shown in Figure 1, greywater reuse applications are generally governed by state regulation or TB MED 577 "Sanitary Control and Surveillance of Field Water Supplies" during military field applications. State regulated water quality standards are typically adopted from nationally recognized guidelines including U.S. EPA Guideline for Water Reuse, NSF International/American National Standards Institute (NSF/ANSI) 350 and 350-1, and plumbing codes, all of which fall under the national standards set by the Clean Water Act (CWA).

Greywater reuse is growing rapidly worldwide, especially in areas of high water stress like Israel, Spain and Australia (Oron et al. 2014). Approaches to and stringency of greywater regulations vary greatly from country to country. Greywater reuse standards from around the world generally exclude kitchen greywater, only governing water from bathtubs, showers, handwashing basins, and washing machines. In some Australian states, untreated greywater can be used for toilet flushing, subsurface irrigation, or both; in others, greywater must be treated (Allen et al 2010; Radcliffe 2010). In Israel, Spain, Japan and Germany, greywater cannot be reused for cleaning dishes (Allen et al. 2010; Gross 2015), and plumbing codes in Canada prohibit the distribution of reclaimed greywater through faucets (Allen et al 2010). In Great Britain, Standard BS 8525-1:2010 specifies water quality guidelines for reclaimed greywater used for doing laundry, washing cars, power-washing outdoor areas, flushing toilets, and watering gardens (Table 1); it does not allow this water to be used for drinking, food preparation, cooking, dishwashing or personal hygiene (British Standards Institution 2010). The World 
Health Origination (WHO) published Guidelines for the safe use of wastewater, excreta and greywater in response to the Millennium Declaration Goals (MDGs) set at the special session of the United Nations General Assembly in 2000. The guidelines are based on a health target of a Disability-adjusted Life Year (DALY) loss of $<10^{-6}$ per person per year. The guidelines deal mostly with agricultural irrigation and do not include dishwater recycling standards (WHO 2006).

Table 1. A selection of greywater reuse standards, guidelines and regulations from around the world

\begin{tabular}{|c|c|c|c|c|c|c|c|}
\hline Parameter & $\mathrm{pH}$ & $\begin{array}{l}\text { Turbidity }^{\mathrm{a}} \\
\text { (NTU) }\end{array}$ & $\begin{array}{c}\mathrm{TSS} \\
(\mathrm{mg} / \mathrm{L})\end{array}$ & $\begin{array}{c}\mathrm{CBOD}_{5}^{\mathrm{a}} \\
(\mathrm{mg} / \mathrm{L})\end{array}$ & $\begin{array}{l}\mathrm{BOD}_{5}{ }^{\mathrm{a}} \\
(\mathrm{mg} / \mathrm{L})\end{array}$ & $\begin{array}{c}\text { Free } \\
\text { Chlorine } \\
(\mathrm{mg} \\
\left.\mathrm{Cl}_{2} / \mathrm{L}\right)\end{array}$ & $\begin{array}{c}\text { Fecal } \\
\text { Coliform }^{\mathrm{b}} \\
\text { (FC/100ml) }\end{array}$ \\
\hline $\begin{array}{c}\text { U.S. Secondary } \\
\text { Treated } \\
\text { Wastewater }\end{array}$ & $\begin{array}{l}6.0- \\
9.0\end{array}$ & $<5$ & $<30$ & $<25$ & $<30$ & - & $<16$ \\
\hline $\begin{array}{l}\text { British Standard } \\
\text { BS 8525-1:2010 }\end{array}$ & $\begin{array}{l}5- \\
9.5\end{array}$ & $\begin{array}{c}<10 \\
\text { (n/a for } \\
\text { garden } \\
\text { watering) }\end{array}$ & - & - & - & $\begin{array}{c}<2.0 \\
(<0.5 \text { for } \\
\text { garden } \\
\text { watering })\end{array}$ & Varies ${ }^{f}$ \\
\hline $\begin{array}{c}\text { International } \\
\text { Plumbing Code }\end{array}$ & - & $<2$ & - & - & - & - & $<2.2^{\mathrm{g}}$ \\
\hline $\begin{array}{l}\text { US EPA and } \\
\text { NSF Guidelines }\end{array}$ & $\begin{array}{l}6.5- \\
8.5\end{array}$ & $<5$ & $<30$ & $<25$ & $<25$ & $0.5-2.5$ & $<14$ \\
\hline $\begin{array}{l}\text { U.S. State } \\
\text { Regulations }\end{array}$ & - & $<2-<5$ & $\begin{array}{l}<5- \\
<30\end{array}$ & $<8-<30$ & $\begin{array}{l}<5- \\
<30\end{array}$ & $\begin{array}{l}\text { N.R. } .^{c} \\
-5\end{array}$ & $<14$ \\
\hline $\begin{array}{l}\text { TB MED } 577 \\
\text { (U.S. Army) }\end{array}$ & $5-9$ & $<10^{\mathrm{d}}$ & - & - & - & $1 \mathrm{mg} / \mathrm{L}$ & N.D. ${ }^{e}$ \\
\hline
\end{tabular}




\subsection{Greywater Regulations and Guidelines in the United States}

\subsubsection{Federal Regulations}

In the U.S., greywater applications and standards are enforced at the state level and fall under the specifications set by the Federal Clean Water Act (USEPA 2012). Under the Clean Water Act, the U.S. EPA Secondary Treatment Standards (40 CFR 133.102) provide national standards for the disposal of wastewater. These standards are as follows; BOD $<30 \mathrm{mg} / \mathrm{L}, \mathrm{TSS}$ $<30 \mathrm{mg} / \mathrm{L}$, pH 6-9, and Turbidity < 5 NTU (Table 1). Because these standards regulate the disposal of all wastewater, they also become the minimum requirements for water reuse regulations and guidelines (USEPA 2012).

\subsubsection{National Guidelines}

\subsubsection{United States Environmental Protection Agency (USEPA)}

The U.S. EPA first developed Guidelines for Water Reuse in 1980 when a need for national guidance on regulations first became apparent (USEPA 2012). The most recent version in 2012 has gained a large influence over regulation with 30 states and several countries utilizing the guidelines. The document contains information on water reuse including; reuse applications, current regulatory programs, treatment technologies, public and environmental health concerns and recommended water quality standards. Although dishwater reuse does not fall into the U.S. EPA guidelines, many water reuse applications are included in the guidelines. These are as follows:

- Irrigation (Agricultural, golf course, and residential)

- Seawater barrier

- Industrial use 
- Groundwater recharge

- Geothermal/energy production
- Natural system restoration

- Toilet flushing

The water quality guidelines set by the U.S. EPA vary depending on application. The largest factor determining the water standard is human exposure. For example, the U.S. EPA recommends that biological oxygen demand $\left(\mathrm{BOD}_{5}\right)$ for water used to irrigate non-food crops remain less than $30 \mathrm{mg} / \mathrm{L}$ and fecal coliforms stay less than 200/100ml, while water used to irrigate food crops needs a BOD less than $10 \mathrm{mg} / \mathrm{L}$ and no detectable fecal coliform $/ 100 \mathrm{ml}$. Table 2 shows an example of standards set by the EPA Guidelines for Water Reuse.

Table 2. EPA guidelines for water reuse (2012): unrestricted urban reuse

\begin{tabular}{cccccc}
\hline Parameter & $\mathrm{pH}$ & $\mathrm{BOD}_{5}$ & Turbidity & $\begin{array}{c}\text { Fecal } \\
\text { coliform }\end{array}$ & $\begin{array}{c}\text { Free chlorine } \\
\text { residual }\end{array}$ \\
\hline Standard & $\begin{array}{c}6.0-9.0 \\
\text { (weekly) }\end{array}$ & $\begin{array}{c}<10 \mathrm{mg} / \mathrm{L} \\
\text { (weekly) }\end{array}$ & $\begin{array}{c}<2 \mathrm{NTU} \\
\text { (continuous) }\end{array}$ & $\begin{array}{c}\text { Non } \\
\text { detectable } \\
\text { (daily) }\end{array}$ & $\begin{array}{c}1 \mathrm{mg} \mathrm{Cl} / \mathrm{L} \\
\text { (continuous) }\end{array}$ \\
\hline
\end{tabular}

\subsubsection{NSF International/American National Standards Institute (NSF/ANSI)}

NSF/ANSI recently came out with guidelines for water reuse which has quickly gained popularity (NSF 2010). The NSF/ANSI Standard 350: On-site Residential and Commercial Water Reuse Treatment Systems and the NSF/ANSI Standard 350-1: On-site Residential and Commercial Graywater Treatment Systems for Subsurface Discharge provide guidance on water quality standards, methods of evaluation, product specifications, and product literature for greywater treatment systems. Along with guidelines, NSF/ANSI attempts to eliminate discrepancies between state regulations by certifying treatment systems. NSF/ANSI certification does not necessarily meet all state regulations, but it does provide a consistent standard 
recognized nationwide. The NSF/ANSI guidelines/certifications are split into two categories: Class $\boldsymbol{R}$ : single-family residential and Class $\boldsymbol{C}$ : multifamily and commercial. Both categories have standards that are unique their class. NSF/ANSI 350-1, like NSF/ANSI 350, is separated into Class $\mathrm{R}$ and $\mathrm{C}$ but only allows for subsurface irrigation. None of the NSF/ANSI standards allow for the use of dishwater.

\subsubsection{Plumbing Codes}

Plumbing codes often have water reuse guidelines and regulations built into their policies. Although most states develop their own regulations for water reuse, there are several cases where state departments (e.g., Department of Environmental Protection [DEP] and the Department of Health) have not developed water reuse standards and leave regulation to the plumbing codes (Yu et al. 2013). Plumbing codes do not normally contain quantitative water quality parameters, but regulate by installing certain treatment requirements (e.g., disinfection, pipe coloring, filtering). States typically adopt nationally or internationally recognized plumbing codes with the Uniform Plumbing Code (UPC) and the International Plumbing Code (IPC) being the most popular.

\subsubsection{State Regulation}

Water reuse regulations are controlled by state or local regulatory agencies (e.g. DEP, Plumbing Codes, and Department of Health) (Yu et al. 2013). The U.S. EPA recognizes 30 states that allow for the reuse of greywater. The other states do not regulate or do not allow greywater reuse. Yu et al. (2013) examined all state regulations for greywater reuse and found that of 29 states that promote greywater reuse, 22 states had internal inconsistencies in regulation. Discrepancies in greywater reuse stems from the adoption of plumbing codes like the UPC (8 
states) or the IPC (10 states), both of which include greywater regulations. These codes often differ from regulations found within environmental, health, or sewage disposal codes. For example, West Virginia's health codes do not allow for greywater reuse, but it has adopted the IPC which contains regulation for the use of greywater. In this example, precedence is given to the stricter regulation (Glenn 2012). Regulations depend on the reuse application; Table 3 provides greywater reuse standards for the state of Florida in the U.S., showing how greywater quality standards differ between different applications.

Table 3. Florida's greywater regulations

\begin{tabular}{|c|c|c|c|c|c|c|}
\hline Application & $\begin{array}{l}\text { Turbidity } \\
\text { (NTU) }\end{array}$ & $\begin{array}{c}\mathrm{TSS} \\
(\mathrm{mg} / \mathrm{L})\end{array}$ & $\begin{array}{l}\mathrm{CBOD}_{5} \\
(\mathrm{mg} / \mathrm{L})\end{array}$ & $\begin{array}{l}\text { Fecal coliforms } \\
\quad(/ 100 \mathrm{~mL})\end{array}$ & $\begin{array}{l}\text { Free chlorine } \\
\left(\mathrm{mg} \mathrm{Cl}_{2} / \mathrm{L}\right)\end{array}$ & Other \\
\hline $\begin{array}{l}\text { Urban- } \\
\text { unrestricted }\end{array}$ & $\begin{array}{c}\mathbf{2 - 2 . 5} \\
\text { (continuous } \\
\text { online } \\
\text { monitoring) }\end{array}$ & $\begin{array}{c}\mathbf{5} \\
(\max .)\end{array}$ & $\begin{array}{c}\mathbf{3 0} \\
\text { (avg. } \\
30 \text { day) } \\
\mathbf{6 0} \\
\text { (max.) }\end{array}$ & $\begin{array}{l}75 \% \text { of samples } \\
\text { below detection } \\
\mathbf{2 5} \text { (max.) }\end{array}$ & $\begin{array}{c}>\mathbf{1 . 0} \\
\text { for } 15 \mathrm{~min}\end{array}$ & $\begin{array}{c}\text { Giardia and } \\
\text { Cryptosporidium } \\
\text { sampling once } \\
\text { every } 2 \text { years }\end{array}$ \\
\hline $\begin{array}{l}\text { Agricultural } \\
\text { reuse } \\
\text { (for food } \\
\text { crops) }\end{array}$ & $\begin{array}{c}\mathbf{2 - 2 . 5} \\
\text { (continuous } \\
\text { online } \\
\text { monitoring) }\end{array}$ & $\begin{array}{c}\mathbf{5} \\
(\max .)\end{array}$ & $\begin{array}{c}\mathbf{3 0} \\
\text { (avg. } \\
30 \text { day) } \\
\mathbf{6 0} \\
\text { (max.) }\end{array}$ & $\begin{array}{l}75 \% \text { of samples } \\
\text { below detection } \\
\mathbf{2 5} \text { (max.) }\end{array}$ & $\begin{array}{c}>\mathbf{1 . 0} \\
\text { for } 15 \mathrm{~min}\end{array}$ & $\begin{array}{c}\text { Giardia and } \\
\text { Cryptosporidium } \\
\text { sampling once } \\
\text { every } 2 \text { years }\end{array}$ \\
\hline $\begin{array}{l}\text { Agricultural } \\
\text { reuse } \\
\text { (for non-food } \\
\text { crops) }\end{array}$ & N.S. & $\begin{array}{c}\mathbf{3 0} \\
\text { (avg. } \\
30 \text { day) } \\
\mathbf{6 0} \\
\text { (max.) }\end{array}$ & $\begin{array}{c}\mathbf{3 0} \\
\text { (avg. } \\
30 \text { day) } \\
\mathbf{6 0} \\
\text { (max.) }\end{array}$ & $\begin{array}{l}200 \text { (avg.) } \\
\mathbf{8 0 0} \text { (max.) }\end{array}$ & $\begin{array}{c}>\mathbf{0 . 5} \\
\text { for } 15 \mathrm{~min}\end{array}$ & - \\
\hline $\begin{array}{l}\text { Groundwater } \\
\text { recharge }\end{array}$ & N.S. & $\begin{array}{c}\mathbf{3 0} \\
\text { (avg. } \\
30 \text { day) } \\
\mathbf{6 0} \\
\text { (max.) }\end{array}$ & $\begin{array}{c}\mathbf{3 0} \\
\text { (avg. } \\
30 \text { day) } \\
\mathbf{6 0} \\
\text { (max.) }\end{array}$ & $\begin{array}{l}200 \text { (avg.) } \\
\mathbf{8 0 0} \text { (max.) }\end{array}$ & $\begin{array}{c}>\mathbf{0 . 5} \\
\text { for } 15 \mathrm{~min}\end{array}$ & $\begin{array}{c}\text { Nitrate }(\mathrm{g} \mathrm{N} / \mathrm{L}) \\
<\mathbf{1 2}\end{array}$ \\
\hline
\end{tabular}




\subsubsection{Military Guidelines}

The U.S. Army is guided by state, federal, or international regulations when not in deployment or in the presence of any host nation requirements (U.S. Army 2010). In areas of active military operations, greywater regulation is guided by TB MED 577 (Sanitary Control and Surveillance of Field Water Supplies) (U.S. Army 2010). Guidelines of TB MED 577 are less stringent than regulations at the state level (Table 2) and include water standards for applications like showering, laundry, and firefighting for field water reuse. These applications are not typically regulated within the states. Although TB MED 577 regulations may be less strict than at the state level, they do comply with the CWA, in particular with Section 402, which pertains to the National Pollutant Discharge Elimination System (EPDES).

The guidelines set by TB MED 577 have water quality standards for the recycling of showering water (Table 4) which provided a reasonable set of standards for the current study due to the characteristics between showering and dishwashing being similar in terms of potential human contact and the use of detergent. Standards for shower water recycling are as follows (TB MED 577): pH 5-9, turbidity <1 NTU, hardness $<500$ mg/L, TDS < 1,500 mg/L, Free chlorine residual $1 \mathrm{mg} \mathrm{Cl} / 2$ after 30 minutes and no presence of coliforms. This guideline was selected as the best candidate for developing dishwater recycling standards.

\section{Table 4. U.S. military showering water standards}

\begin{tabular}{ccccc}
\hline & 1980 & 1984 & 1986 & 2010 \\
\hline $\mathrm{pH}$ & $6.5-7.5$ & $4.5-9.5$ & $6.4-7.5$ & $5-9$ \\
& $<1$ desirable & & & \\
Turbidity (NTU) & $\begin{array}{c}< \\
\text { permissible }\end{array}$ & & $<5$ & $<1$ \\
\hline
\end{tabular}




\begin{tabular}{ccccc}
\hline & 1980 & 1984 & 1986 & 2010 \\
\hline \multirow{2}{*}{$\begin{array}{c}5 \mathrm{mg} / \mathrm{L} \\
\text { residual }\end{array}$} & $5 \mathrm{mg} / \mathrm{L}$ & $5 \mathrm{mg} / \mathrm{L}$ & \\
& $\left(>20^{\circ} \mathrm{C}\right)$ & $\left(>20^{\circ} \mathrm{C}\right)$ & $\left(>20^{\circ} \mathrm{C}\right)$ & $1 \mathrm{mg} / \mathrm{L}$ after \\
& $(10 \mathrm{mg} / \mathrm{L}$ & $10 \mathrm{mg} / \mathrm{L}$ & $10 \mathrm{mg} / \mathrm{L}$ & $30 \mathrm{minutes}$ \\
$\left(<20^{\circ} \mathrm{C}\right)$ & $\left(<20^{\circ} \mathrm{C}\right)$ & $\left(<20^{\circ} \mathrm{C}\right)$ & \\
Hardness & & & & $500 \mathrm{mg} / \mathrm{L}$ \\
& - & & & \\
Total dissolved solids \\
(TDS)
\end{tabular}

Source: Engelbrecht 1986, U.S. Army 2010

\subsection{Dishwater Characteristics}

Greywater is domestic wastewater from non-toilet sources like showers, bathtubs, sinks, and washing machines. The wastewaters from kitchen sinks and dishwashers are referred to as dark greywater and are rarely used for urban reuse (Yu et al. 2013). Currently, there are no developed standards for dishwater recycling. Therefore, it is important to consider the potential health risks associated with dishwater reuse for the development of water quality standards for dishwater recycling. Contaminants of dishwater include chemical and microbial components. A large contributor to chemical contamination of dishwater is from the use of detergents. Chemicals in commercial dish detergents include anionic/nonionic surfactants, salts, dyes, perfumes and ethanol (Erickson 2007). Microbiological contaminants are also a major problem with kitchen greywater. Fecal coliforms levels as high as 2,400,000/100ml have been found in samples of kitchen sink water (Burrows et al. 1991). Table 5 shows examples of various dishwasher water quality. The characteristics of dishwater are highly variable depending on the type of detergent (e.g., non-ionic and anionic), foods, components of surfactant (e.g., 
ingredients), and the dishwashing habits of the people involved (e.g., amount of surfactant use)

(Eriksson et al. 2002).

Table 5. Examples of dishwater quality

\begin{tabular}{ccc}
\hline Parameter & Friedler 2004 & Siegrist et al. 1976 \\
\hline $\mathrm{pH}$ & 8.2 & - \\
EC (electrical conductivity) & $2,721 \mu \mathrm{S} / \mathrm{cm}$ & - \\
TSS (total suspended solids) & $1,045 \mathrm{mg} / \mathrm{L}$ & $440 \mathrm{mg} / \mathrm{L}$ \\
COD (chemical oxygen demands) & $1,296 \mathrm{mg} / \mathrm{L}$ & - \\
BOD (biological oxygen demands) & $699 \mathrm{mg} / \mathrm{L}$ & $1,040 \mathrm{mg} / \mathrm{L}$ \\
TOC (total organic carbon) & $234 \mathrm{mg} / \mathrm{L}$ & $600 \mathrm{mg} / \mathrm{L}$ \\
Total oil & $328 \mathrm{mg} / \mathrm{L}$ & - \\
$\mathrm{NH}$-N & $5.4 \mathrm{mg} / \mathrm{L}$ & $4.5 \mathrm{mg} / \mathrm{L}$ \\
$\mathrm{P}$ & $537 \mathrm{mg} / \mathrm{L}$ & $68 \mathrm{mg} / \mathrm{L}$ \\
$\mathrm{Cl}$ & $716 \mathrm{mg} / \mathrm{L}$ & - \\
$\mathrm{B}$ & $3.8 \mathrm{mg} / \mathrm{L}$ & - \\
$\mathrm{Na}$ & $641 \mathrm{mg} / \mathrm{L}$ & - \\
FC (fecal coliform) & $6.0 \times 104 / 100 \mathrm{ml}$ & - \\
\hline
\end{tabular}

\subsection{Health Concerns Associated with Dishwater}

\subsubsection{Chemical Components}

\subsubsection{Detergents}

Detergents are a major source of chemical contamination in dishwater. In general, dish detergents contain surfactants, salts, perfumes, ethanol, and dyes. Due to the diversity of chemicals (e.g., acidic or basic compounds) used in detergents, the $\mathrm{pH}$ of dishwater is highly 
variable. Detergents are also sources of nitrates, sulfates, and phosphates which, when dissolved in water, may lead to formation of disinfection by products (DBP) (Pidou et al. 2007). Triclosan, an antibacterial agent found in some detergents, is a DBP precursor, a known endocrine disrupter, and could produce drug resistance bacteria (Rule et al. 2005). Most surfactants used in detergents are sulphonate and sulphate based which have been shown to have harmful biological effects on health and the environment. A major concern is endocrine disrupting properties of surfactants. A study by Tripathi et al. showed sexual disruption in rainbow trout with surfactant levels as low as $0.1 \mathrm{mg} / \mathrm{L}$ (Tripathi et al. 2013).

\subsubsection{Organic Matter}

Food particulates, fats, and oils cause dishwater to have organic concentrations as high as $880 \mathrm{mg} / \mathrm{L}$ TOC (Eriksson et al. 2002). In addition to promoting growth of pathogenic bacteria and other microorganisms, organic pollutants can have an effect on human health. It is difficult to predict human effects of exposure to a complex mixture of organics; however, there are studies involving the health effects of specific organic molecules found in greywater. Phthalates, for example, are commonly found in greywater and have toxicological properties including the disruption of the endocrine system (Hamlyn-Harris 2001).

\subsubsection{Disinfection Byproducts (DBP)}

Chlorination is a popular disinfection method because the residual concentration in the system maintains safe levels of microbial contamination (Najm et al. 1994); however, chlorine can form a broad range of DBP by reacting with natural organic matter (NOM). A study from Kim et al. (2002) shows the strong relationship between total organic carbon and disinfection byproducts. Although the dishwater will not be ingested, DBP are volatile, leading to inhalation 
and dermal adsorption (Florentin et al. 2011). Studies have shown that prolonged exposure to volatile DBP (>250 hours) can cause asthma (Weisel et al. 2009), reproductive issues, and bladder cancer (Villanueva et al. 2007). In addition, only a fraction of DBP have been studied leaving uncertainty to the true scale at which health can be affected (LaKind et al. 2010).

\subsubsection{Microbiological Components}

Microbiological quality of water is directly related to human health making it a primary concern for most water reuse regulations. Dishwater contains large amount of microbes with concentrations ranging from $6.0 \times 10^{4} \mathrm{cfu}$ (colony forming units) $/ 100 \mathrm{ml}$ to $2.3 \times 10^{6} \mathrm{cfu} / 100 \mathrm{ml}$ (Eriksson et al. 2002). These microorganisms are capable of causing severe illness, requiring disinfection of reused water to eliminate any potential health effects. Waterborne microorganisms can fall into four categories; viruses, bacteria, protozoa, and Helminths (Burrows et al. 1991).

- Viruses: Hepatitis A and Norwalk virus

- Bacteria: E. Coli, Salmonella, Listeria, Bacillus cereus and Staphylococcus aurous

- Protozoa: Cryptosporidium, Giardia, Endameba, Cyclospora and Microsporidia

- Helminths: Roundworms and flatworms

Microbial quality of greywater depends on the types of treatment level, as follows:

\section{Types of reclaimed water by treatment level}

Potable Reuse

Disinfected Tertiary Reclaimed Water

Disinfected Secondary Reclaimed Water

Undisinfected Reclaimed Water

Greywater

Dishwater

Raw Wastewater
Microbial Quality of Greywater

(\# of organisms per $100 \mathrm{ml}$ )

None

$<2.2$

$<23$

20 to 2,000

100 to 100 million

Thousands to billions

Millions to billions 


\subsection{Parameters for Water Quality Standards}

There are many physical, chemical and biological water quality parameters for evaluating water after greywater treatment. While there are water parameters which can easily be measured (e.g., $\mathrm{pH}$ and turbidity), others are time-consuming, complicated, and not applicable for field use. For the purpose of this thesis, several water parameters were evaluated to find correlations between one or two easily measurable parameters for field use and parameters that need to be measured in the laboratory. Particularly, water quality parameters for field testing need to be quick and simple to measure, while also providing valuable information on water quality.

\subsubsection{Field Parameters}

\section{$\underline{2.5 .1 .1 \mathrm{pH}}$}

$\mathrm{pH}$ is an important water quality parameter that influences the effectiveness of a treatment system (e.g., electrocoagulation and chlorination). It is normally kept in a narrow window, between 6-8, to prevent corrosion and problems with disinfection. Using $\mathrm{pH}$ as a parameter for water quality is particularly useful for field application because measurement is taken using a simple $\mathrm{pH}$ meter or strips. An example of $\mathrm{pH}$ as a parameter is the U.S. EPA guidelines for water reuse which requires a pH between 6-9 (USEPA 2012).

\subsubsection{Turbidity}

Turbidity is the measure of cloudiness of water. Materials responsible for the cloudiness of water include algae, planktonic microbes and soil particles. Turbidity can shield pathogens from disinfection which makes it a common parameter in water treatment. It is generally accepted that turbidity needs to be below 1 NTU for effective disinfection. Turbidity is easily measured with a nephelometer and is a good indicator of treatment effectiveness (USEPA 
2012). One example of turbidity being used as a standards parameter is that U.S. EPA requires $95 \%$ of drinking water samples to have a turbidity of less than 0.3 NTU in a 30 day period (USEPA, 2012).

\subsubsection{Free available chlorine (FAC)}

FAC is the measure of chlorine available for disinfection. Free available chlorine is a popular water reuse parameter because it maintains disinfection. Typical greywater applications require $\mathrm{FAC}$ levels to fall between $0.5 \mathrm{mg} \mathrm{Cl} / \mathrm{L}$ and $5 \mathrm{mg} \mathrm{Cl}_{2} / \mathrm{L}$ (USEPA, 2012).

\subsubsection{Conductivity}

Conductivity is the measure of water's ability to pass an electrical current. A water's conductivity is affected by the presence of anions (e.g., $\mathrm{Cl}^{-}, \mathrm{SO}_{4}{ }^{2-}, \mathrm{NO}_{3}{ }^{-}$, and $\mathrm{PO}_{4}{ }^{3-}$ ) or cations (e.g., $\mathrm{Na}^{+}, \mathrm{Al}^{3+}$, and $\mathrm{Fe}^{3+}$ ). Conductivity closely relates to total dissolved solids (TDS) which is commonly used in water quality standards (USEPA 2012, WHO 2006, and US Army 2010). Conductivity measurements are simple and immediate with the use of a conductivity meter.

\subsubsection{5 $\mathrm{UV}_{254}$}

$\mathrm{UV}_{254}$ is a method for determining the amount of organics in a sample by measuring $\mathrm{UV}$ adsorption at $254 \mathrm{~nm}$. Aromatic compounds tend to absorb light at this wavelength which can be used to determine the concentration of aromatic containing molecules in the water. $\mathrm{UV}_{254}$ is a useful field parameter because it is relatively simple to perform and only needs a UV spectrometer. In addition, $\mathrm{UV}_{254}$ absorption is strongly related to DBP (Najm et al 1994). 


\subsubsection{Non-Field Parameters}

\subsubsection{Biological Oxygen Demand (BOD)}

$\mathrm{BOD}$ is the measure of oxygen consumed by microorganisms and is directly related to concentration of biodegradable substances in water. BOD is common parameter used in waste water regulation which has been used since 1908 (Hamlyn-Harris 2001). BOD has been included in greywater regulation including standards set by the U.S. EPA, WHO and state level regulation.

\subsubsection{Chemical Oxygen Demand (COD)}

COD is similar to BOD except COD measures the amount of all chemicals that can be oxidized, not just biologically oxidized substances (Hamlyn-Harris 2001). An example of COD in regulation is the city of Windhoek, Namibia, which requires their drinking water COD to be less than 20mg/L (du Pisani 2006).

\subsubsection{Total Organic Carbon (TOC)}

TOC is the amount of carbon incorporated into to organic matter. A report produced by Gutteridge Haskins \& Davey Pty Ltd (Hamlyn-Harris 2001) recommended TOC as a parameter

for water quality of direct potable reuse because of its establishment as a surrogate of health risk associated with organic compounds present in water. An example of TOC in water reuse regulation is standards set by the state of Florida, requiring a monthly average for indirect potable reuse to have a TOC less than $0.3 \mathrm{mg} / \mathrm{L}$.

\subsubsection{Total Dissolved Solids (TDS)}

TDS measures the substances, inorganic and organic, found in water. TDS are usually salts including calcium, magnesium, sodium, sulfates and nitrates. No recent data shows a 
relationship between TDS in drinking water and serious health effects, however, excessive TDS (i.e., greater than 1,500 mg/L) can lead to scaling (Hamlyn-Harris 2001). An example of TDS in greywater regulation is that TB MED 577 requires TDS to be less than 2,000 $\mathrm{mg} / \mathrm{L}$ for water reuse (U.S. Army 2010).

\subsubsection{Nitrogen}

Nitrogen exists in many forms including nitrate, nitrite, and ammonia. Ammonia levels can have a negative effect on aquatic life because of its toxic nature. Nitrate and nitrite levels can promote growth of bacteria and algae causing eutrophication. An example of nitrogen as a parameter in water reuse regulation is Arizona's urban reuse regulation requires less than 10 $\mathrm{mg} / \mathrm{L}$ total nitrogen $(\mathrm{TN})$.

\subsubsection{Phosphorous}

Phosphorus is typically the limiting nutrient for plant growth, meaning a sudden increase in phosphorus levels can cause eutrophication. Therefore, phosphorus is typically controlled for environmental water reuse applications. An example of phosphorous in water reuse regulation is Florida's environmental reuse regulation requiring less than $2 \mathrm{mg} / \mathrm{L}$ phosphorous.

\subsubsection{Surfactants}

Buildup of surfactant could be a concern if not properly monitored. Although the risk is small, surfactants have been shown to disrupt endocrine systems of humans and animals. Studies have found that surfactants can have harmful environmental impacts at concentrations above 0.1 $\mathrm{mg} / \mathrm{L}$ (Tripathi et al. 2013). 


\subsubsection{Oil and Grease $(\mathrm{O} \& \mathrm{G})$}

Dishwater is known to contain large amounts of oil and grease. $O \& G$ is a common parameter for wastewater treatment because of public health and pipe clogging problems. An example of $\mathrm{O} \& \mathrm{G}$ in water regulation is Philippine class $\mathrm{C}$ wastewater requires $\mathrm{O} \& \mathrm{G}$ to be below $5 \mathrm{mg} / \mathrm{L}$ (USEPA 2012).

\subsubsection{Fecal Coliforms/E. Coli}

Fecal coliforms and E. coli are used as an indicator of pathogenic bacteria, viruses, and protozoans. High levels of fecal coliform can mean high levels of pathogenic bacteria that can pose a serious threat to human health. Recently, U.S. EPA recommended the use of E. coli as an indicator and states are beginning to change their standards accordingly (Hamlyn-Harris 2001). E.coli can easily be measured using Colilert/Quanti tray system (IDEXX) using only a few pieces of equipment and a turnaround time of 24 hours. Many greywater standards required the absence of fecal coliform per 100mL.

\subsection{Initial Water Quality Standards for Dishwater Reuse}

Available literature on the development of greywater reuse regulation was extensively reviewed to obtain the overall understanding of existing water quality parameters and standards. The driving force behind all the standards seems to be human health. One parameter directly dealing with human health is microbial contaminates, thus requiring chlorine disinfection. $\mathrm{BOD}_{5}$ is widely used for state regulation to prevent biological growth. The shower reuse standards from TB MED 577 most closely regulate in the scope of dishwater recycling; however, it has no requirements on $\mathrm{BOD}_{5}$, but limits coliforms to absent per $100 \mathrm{~mL}$. 
There are many physical, chemical and biological water quality parameters for evaluating water after greywater treatment (Salgot et al. 2006). While some water parameters can easily be measured (e.g., $\mathrm{pH}$ and turbidity), some are time-consuming, complicated, and not applicable for field use. For the scope of the project, various water quality parameters were evaluated to recommend for field use. Particularly, the field testing methods need to be rapid and simple to measure, while also providing accurate information on water quality.

Turbidity, $\mathrm{pH}$, and $\mathrm{UV}_{254}$ were selected as important parameters for field use of dishwasher recycle based on literature review. In addition, chlorine residual was also considered as an important parameter to ensure disinfection. For public safety, there should be no detectable coliforms or E. coli present in the treated greywater. By removing or inactivating most microbes, the risk of waterborne illness is significantly reduced (Schneider 2009).

Many microbial containments will be removed by ultrafiltration (Hagen 1998). As an additional barrier for potential pathogenic hazards, a chlorine residual of at least $1 \mathrm{mg} \mathrm{Cl} / \mathrm{L}$ will help achieve a high level of inactivation. It is recommended that $\mathrm{BOD}_{5}$ should be maintained at values below $30 \mathrm{mg} / \mathrm{L}$ for water reuse; $30 \mathrm{mg} / \mathrm{L}$ is the limit set by the U.S. EPA Secondary Standards as well as other state regulations for greywater reuse. High $\mathrm{BOD}_{5}$ (e.g., above 20 $\mathrm{mg} / \mathrm{L}$ ) is expected to produce DBP and promote bacteria growth (e.g., biological contamination). Since $\mathrm{BOD}_{5}$ and other organic parameters (e.g., TOC and COD) are not easily measured in field environments, $\mathrm{UV}_{254}$ will ensure proper levels of organics.

Turbidity and $\mathrm{pH}$ are easily measured parameters that can provide information on the effectiveness of the recycling treatment. High turbidity above $5 \mathrm{NTU}$ or outranged $\mathrm{pH}$ values $(<$ $\mathrm{pH} 6$ or $>\mathrm{pH} 9$ ) could indicate a failure in the system. Below is the summary of recommended standards for dishwater reuse based on available literature. 
- Lab test: General water quality requirement

○ $\mathrm{pH} 6-9$

- Turbidity $<5 \mathrm{NTU}$

- Free chlorine (in the storage tank) : $1-5 \mathrm{mg} \mathrm{Cl}_{2} / \mathrm{L}$

- $\mathrm{UV}_{254}$ (to provide the correlation with organic parameter such as $\mathrm{BOD}_{5}$ )

- $\mathrm{BOD}_{5}<30 \mathrm{mg} / \mathrm{L}$

- $\mathrm{TSS}<30 \mathrm{mg} / \mathrm{L}$

○ Total coliform $<$ None (CFUs/100 mL or MPN/100 mL)

- Field application: Minimum water quality requirement

○ $\mathrm{pH} 6-9$

$\circ$ Turbidity $<5 \mathrm{NTU}$

- Free chlorine (in the storage tank): $1-5 \mathrm{mg} \mathrm{Cl}_{2} / \mathrm{L}$

- $\mathrm{UV}_{254}$ (as surrogate for organics such as $\mathrm{BOD}_{5}$ )

- The correlation with $\mathrm{BOD}_{5}$ should be evaluated in the laboratory and calibration curves should be created to use $\mathrm{UV}_{254}$ in field 


\section{CHAPTER THREE: EVALUATION OF A DISHWASHING WATER RECYCLING SYSTEM}

\subsection{Dishwashing Water Recycling System}

A full-scale prototype dishwashing water recycling system was constructed and operated by Mainstream Engineering Corporation (Rockledge, FL, USA) over the course of year (Figure 2). Water collected from three 20 gallon (76 L) sinks (wash, rinse, and sanitize) was first treated by electrocoagulation using zinc electrodes to destabilize emulsions and precipitate suspended particles from the high-pH greywater (due to detergents used in dishwashing). Then the water was further processed by ultrafiltration (UF) using a hollow fiber, cross-flow, and modified polyethersulfone membrane (WaterSep, Marlborough, MA, USA) with a molecular weight cutoff of $750 \mathrm{kDA}$ (Amundsen et al., 2013). A standard issue powdered detergent soap (NSN 7930-00-281-4731, NuGentec, Emeryville, California) was supplied as a detergent and a preliminary analysis showed that the detergent's $\mathrm{pH}$ was 9.4 and includes sodium phosphate derivative anionic surfactant (Appendix A). The electrocoagulation (EC) system was constructed with PVC with dimensions of $27 \mathrm{~cm}(\mathrm{H}) \times 5 \mathrm{~cm}(\mathrm{~L}) \times 6 \mathrm{~cm}(\mathrm{~W})$. The electrodes were constructed with zinc, measuring $27 \mathrm{~cm}(\mathrm{H}) \times 5 \mathrm{~cm}(\mathrm{~L}) \times 0.3 \mathrm{~cm}(\mathrm{~W})$, and were separated by $0.6 \mathrm{~cm}$. The seven electrode plates were placed in the cell with one electrode as the anode, one electrode as the cathode (the anode and cathode were located at opposite ends of the reactor) and five inner plates operating in a bipolar fashion. The total electrode area was $810 \mathrm{~cm}^{2}$ with an applied potential of $20 \mathrm{~V}$ (AC). The current density was $1.85 \mathrm{~mA} / \mathrm{cm}^{2}$ and the cell residence time was $7 \mathrm{~min}$. The UF membrane was operated at $25^{\circ} \mathrm{C}$ with a transmembrane pressure of $0.10 \mathrm{MPa}$ and a feed flow rate of $400 \mathrm{~mL} / \mathrm{min}$. The filter was back flushed for $30 \mathrm{sec}$ every 3 min at $0.14 \mathrm{MPa}$ using 
permeate. The filter was also cleaned, alternating between white vinegar and $1.0 \mathrm{M} \mathrm{NaOH}$ for 10 min for every 4 hrs of runtime. Samples were collected weekly for testing.

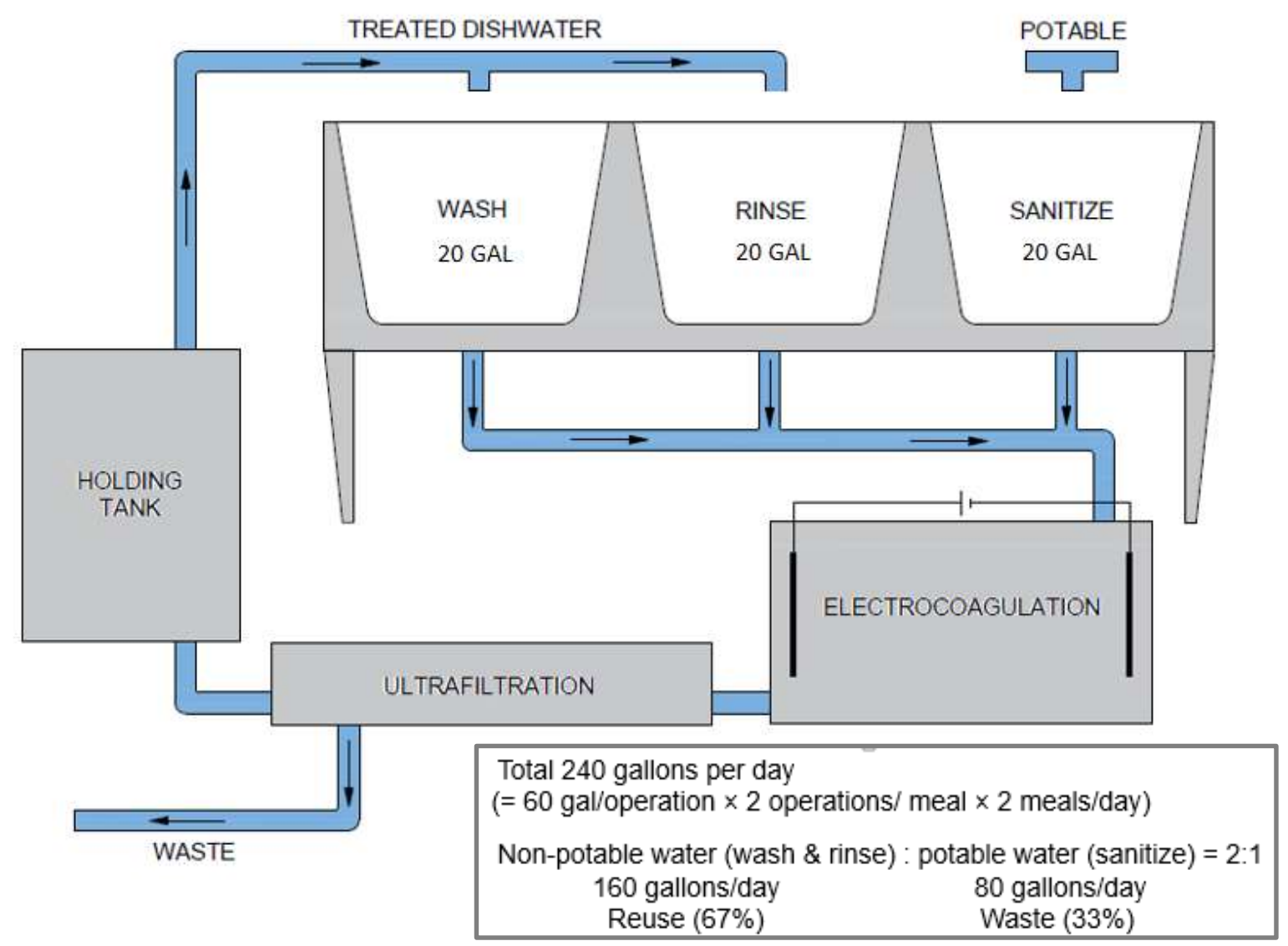

Figure 2. Schematic diagram of a greywater recycling process for dishwashing water.

A synthetic surrogate dishwashing water used during the system operation as a representative sample of U.S. Army field dishwashing water. Concentrated food mixture (3 kg baked beans, $1.28 \mathrm{~kg}$ chili con carne and $1.9 \mathrm{~L}$ of water) $(8.3 \mathrm{~mL})$, vegetable oil $(2.5 \mathrm{~mL})$ and NSN 7930-00-281-4731 dishwashing soap (20.0 g) were combined with $3.79 \mathrm{~L}$ (1 gallon) of fresh tap water to produce the synthetic greywater with a $\mathrm{BOD}_{5}$ of $1,000 \mathrm{mg} / \mathrm{L}$ and TSS of 850 mg/L (Natick Soldier Center, 2007). 


\subsection{Methodology}

\subsubsection{Water Quality Analysis}

On-site samples were collected from the dishwater recycle device at $25^{\circ} \mathrm{C}$ and analyzed in the UCF laboratories within 3-6 hrs. Sample collection was performed in accordance with Standard Methods for the Examination of Water and Wastewater (APHA, AWWA, and WEF, 1998). The parameters measured included $\mathrm{BOD}_{5}, \mathrm{COD}$, TSS, TDS, total phosphorus (TP), $\mathrm{pH}$, temperature, total organic carbon (TOC) (SM 5310), $\mathrm{UV}_{254}$ (EPA 415.3), SUVA (EPA 415.3), trihalomethanes (THMs) (SM 6232 B), and haloacetic acids (HAAs) (EPA 552.2). HAAs were analyzed by a certified external lab (Advanced Environmental Laboratories, Inc. Altamonte Springs FL, USA).

\subsubsection{Potential Microbial Growth: The Effect of Surfactant and Ultrafiltration Treatment of Dishwashing Water on E. Coli.}

The current water recycling system contains multiple barriers to remove microbial contaminants: zinc electrocoagulation, ultrafiltration, and chlorination. However, under specific (or undesirable) circumstances in field operations (e.g., hot weather condition), it may not be easy to maintain the chlorine residuals required for bacterial control in the chlorinated holding tank. In this case, the presence of surfactants may inhibit bacterial growth, or cause their decay, during the event of the absence of free chlorine. Therefore, the degree of disinfection by contacting with the surfactant only (without chlorination) was evaluated in batch experiments.

E. coli was selected as a model bacteria for microbiological testing because of its use as an indicator organism in U.S. greywater regulations (USEPA 2012). E. coli (K-12 strain S 4362, ATCC 29181) was propagated in tryptic soy broth (Difco, Detroit, MI), following 
manufacturer's specifications, and incubated for $48 \mathrm{hrs}$ at $37^{\circ} \mathrm{C}$. After allowing the E. coli to stabilize ( 5 days at $\left.37^{\circ} \mathrm{C}\right), 0.5 \mathrm{~mL}$ of the liquid culture $\left(3.6 \times 10^{8} \mathrm{CFU} / 100 \mathrm{ml}\right)$ was added to five beakers with $500 \mathrm{~mL}$ of sterilized (autoclaved) UF/EC treated synthetic dishwater and different detergents and surfactants (1) no detergent, 2) powdered detergent (NSN 7930-00-281-4731, NuGentec, Emeryville, California,) 3) anionic surfactant (sodium lauryl sulfate), 4) cationic surfactant (cethyl trimethylammonium chloride (CTAC)), and 5) nonionic surfactant (Triton X100)). The UF/EC synthetic dishwater was produced by treating synthetic dishwashing water (recipe described in section 4.1) with the developed UF/EC treatment system (i.e., one-cycle system operation) without detergent. Surfactant was then added to produce a $0.05 \mathrm{~N}$ solution which is typical of U.S. dishwashing water (Lai 2012). The manufacturer recommended amount

of standard issued powdered detergent $(5.3 \mathrm{~g} / \mathrm{L})$ was used which contains an unknown amount of surfactant. Treated greywater without surfactant or detergent was used as a control. The dishwater environments were maintained at $37^{\circ} \mathrm{C} \pm 1^{\circ} \mathrm{C}$ and continuously stirred using a hot plate and magnetic stirrer. Triplicate samples were aseptically withdrawn from each environment at 5, 60, 120, and 240 minutes for quantification of E. coli. E. coli concentrations were determined using spread plate technique with dilutions on Nutrient Agar (Difco, Detroit, MI). Colony forming units (cfu) were counted after a 48-hour incubation period and E. coli was verified through inspection of colony morphology (Johansson et al. 2005).

\subsubsection{Chlorine Demand and Disinfection by-Product Formation Potential (DBFP) of Treated Dishwashing Water}

Most regulations, including the U.S. EPA Guidelines for Water Reuse, NSF/ANSI 350-1 and many state regulations, require a hydraulic retention time (HRT) of less than 24 hrs for a water storage tank. Therefore, it is recommended to set a HRT of $24 \mathrm{hrs}$ for the chlorinated 
holding tank of the dishwater recycling system. This will retain water quality by limiting the time for residual depletion and bacterial growth. A HRT of $48 \mathrm{hrs}$ or more is also sometimes recommended in some state regulations (USEPA 2012) and plumbing codes (IPC 1302.1). Therefore, batch tests for chlorine demand were conducted for HRT periods of 24 and $48 \mathrm{hrs}$. The treated greywater chlorinated holding tank could be a potential source of bacterial growth if the desired chlorine residuals are not maintained; however, chlorine can also react with NOM to form a broad range of DBP which are a concern to human health (Jumpatong and Buddhasukh 2003). Not only are DBP a concern if ingested, they are also volatile and can be inhaled or adsorbed dermally (Hagen 1998). Although the dishwater will not be ingested, chlorine demands for the treated water, along with DBP formation potential (DBPFP), was evaluated because of the relatively high organic levels (100 $\mathrm{mg} \mathrm{C/L})$. The treated dishwashing water $(\mathrm{pH} 9.6 \pm 0.1)$ was dosed with sodium hypochlorite (SS290-1, Fisher Scientific) and incubated at $32^{\circ} \mathrm{C}$ for different times $(2,4,6,24$, and $48 \mathrm{hrs}) \cdot 32^{\circ} \mathrm{C}$ was used to simulate hot water usage. A preliminary test with a single dose of $50 \mathrm{mg} \mathrm{Cl} / 2$ showed chlorine depletion within $24 \mathrm{hrs}$; assumed to be due to high TOC (data not shown). In this study, chlorine doses were also increased to 60, 70, and 75 $\mathrm{mg} \mathrm{Cl} / \mathrm{L}$ and chlorine residuals were measured over time during $48 \mathrm{hrs}$.

\subsubsection{Quantitative Microbial Risk Assessment (QMRA)}

Dishwashing water could become contaminated with pathogens when dishes and other kitchen utensils become contaminated during food preparation (Ståhl Warnersson et al. 2004). The use of electrocoagulation, ultrafiltration and chlorination to treat contaminated dishwater should eliminate pathogens present; however, there may be some exceptions. For example, Westrell et al. (2003) reported that virus removal in single-membrane ultrafiltration systems can 
be as low as one $\log 10$ unit, due to micro-defects in filter construction, partially-damaged membranes, and leaky seals (Westrell et al. 2003). Also, bacteria may be able to form biofilms on the product side of membranes (Jacangelo et al. 1989), and pathogens could persist or, in the case of bacteria, grow within the holding tank. There are also many viruses known to have a high resistance to chlorination (Black et al. 2009).

The QMRA model for this study was designed with the help of Mr. Matt Verbyla at the University of South Florida to estimate the maximum tolerable concentrations of three reference pathogens (human norovirus, Salmonella spp. (non-typhi), and E. coli O157:H7) in the recycled dishwater. The assumptions for the parameters used in the QMRA model are provided in Table 6. Human norovirus was chosen as a reference viral pathogen because it is non-enveloped, highly infectious (Le Pendu et al. 2006), and has been known to cause both water- and foodrelated outbreaks (Goodgame 2007). Salmonella spp. was chosen as a reference pathogen group because they have been widely associated with foodborne outbreaks and some serotypes are very hazardous to humans (USEPA 2010). Finally, Shiga toxin-producing E. coli strain O157:H7 was chosen as a reference pathogen since it has been implicated in many foodborne outbreaks (FSIS 2001), and therefore is potentially present in food preparation materials and utensils. For human norovirus, a small proportion of the population may have genetic resistance to infection; however, for the purposes of this QMRA, it was assumed that all individuals may be susceptible (Soller et al. 2010). The same assumptions were made for Salmonella and E. coli O157:H7.

Not all microbial infections will result in an illness. The percentage of norovirus infections resulting in illness was determined using a dose-dependent model proposed by Teunis et al. (2008) (see Table 6). For Salmonella and E. coli O157:H7, it was assumed that 20\% and $28 \%$ of all infections would result in illness (Soller et al. 2010). 
Table 6. QMRA model parameter assumptions

\begin{tabular}{llll}
\hline Parameter & Units & Value or Distribution & References \\
\hline Acceptable Risk of Illness & & \\
\hline & & $\begin{array}{l}\text { Two orders of } \\
\text { magnitude less } \\
\text { than the current }\end{array}$ \\
$\begin{array}{lll}\text { Maximum tolerable cases } \\
\text { of illness }\end{array}$ & ratio & 1 in 50,000 exposures & $\begin{array}{l}\text { estimated disease } \\
\text { incidence for } \\
\text { military field } \\
\text { personnel (Riddle } \\
\end{array}$ \\
& & et al. 2006) \\
\hline
\end{tabular}

Exposure to Pathogens

Volume ingested for direct potable reuse

$\mathrm{mL} /$ person/day $\quad V=3,000$

(USEPA 2011)

Volume accidentally ingested during reuse for $\mathrm{mL} /$ person/day $\quad V=1$

(Ottoson and irrigation Stenstrom 2003)

Volume accidentally ingested during reuse for dishwashing

$\mathrm{mL} /$ person/day $\quad V=1$

Assumed to be the same as irrigation

Volume accidentally ingested during reuse for showering

$V=1.9$

$\mathrm{mL} /$ person/day

(assumes two 7-minute showers per person per day)

(Ahmed et al.

2010)

\section{Dose-Response Models}

Norovirus
(based on best fit
parameters for 8fIIa \& 8fIIb
inocula)

Salmonella spp.

E. coli $\mathrm{O} 157: \mathrm{H} 7$
Hypergeometric model:

$\alpha=0.04, \beta=0.055, \eta_{N V}=0.00255, r_{N V} \quad$ (Teunis et al., $=0.086, a=0.9997$ 2008)

Approximate Beta-Poisson model: $\alpha=0.3126, \beta=2884$

(Soller et al., 2010)

(Soller et al.,
Approximate Beta-Poisson model: $\alpha=0.1705, \beta=1.61 \times 10^{6}$
2010)

Probability of Infection Resulting in Illness

\begin{tabular}{llll}
\hline & & & \\
& NoV: & (Soller et al., \\
Illness:Infection $(I)$ & probability; & $p_{\text {ill linf }}=1-\left(1+\eta_{N V} c_{N V} V\right)^{-r_{N V}}$ & 2010; Teunis et \\
& proportion & Salmonella: 0.2 & al., 2008) \\
& & E. coli: 0.28 & \\
\hline
\end{tabular}




\section{$\underline{3.3 \text { Results }}$}

\subsubsection{Effluent Water Characteristics}

Table 7 shows the effluent characteristics of the dishwashing water recycling system. $\mathrm{BOD}_{5}$, and COD were significantly reduced after ultrafiltration with average concentrations of 65 (93.5\% removal) and 708 (64.6\% removal), respectively. The system also produced water with TSS, TDS, and turbidity of $16 \mathrm{mg} / \mathrm{L}$ (98.1\% removal), 2,650 mg/L, and $0.3 \mathrm{NTU}(99.6 \%$ removal), respectively, with a $\mathrm{pH}$ of 9.5. The value of the SUVA was relatively low indicating that the large aromatic molecules are being adsorbed and filtered out by coagulation and ultrafiltration (de la Rubia et al. 2008). The values of effluent water quality still exceeded typical greywater reuse standards (Table 3), but fresh potable water at an elevated temperature will be used for the sanitization step, resulting in the dilution of any treated water droplets which are carried over when dishes are transferred from the rinse stage to the sanitation (final) stage of the dishwashing process.

Table 7. Developed dishwashing water recycling system effluent characteristics

\begin{tabular}{cccc}
\hline Parameter & Influent & $\begin{array}{c}\text { Effluent from the } \\
\text { developed system }\end{array}$ & $\begin{array}{c}\text { Typical greywater } \\
\text { reuse standards }\end{array}$ \\
\hline $\mathrm{BOD}_{5}(\mathrm{mg} / \mathrm{L})$ & 1,000 & $65^{\mathrm{a}}$ & 30 \\
$\mathrm{COD}(\mathrm{mg} / \mathrm{L})$ & 2,000 & $708^{\mathrm{a}}$ & 100 \\
TOC $(\mathrm{mg} / \mathrm{L})$ & - & $92.5 \pm 5.2$ & No standard \\
$\mathrm{pH}$ & - & $9.5 \pm 0.4$ & $6.0-9.0$ \\
Turbidity $(\mathrm{NTU})$ & 450 & $0.325 \pm 0.014$ & 5 \\
\hline
\end{tabular}




\begin{tabular}{cccc}
\hline Parameter & Influent & $\begin{array}{c}\text { Effluent from the } \\
\text { developed system }\end{array}$ & $\begin{array}{c}\text { Typical greywater } \\
\text { reuse standards }\end{array}$ \\
\hline TSS $(\mathrm{mg} / \mathrm{L})$ & 850 & $16^{\mathrm{a}}$ & 30 \\
TDS $(\mathrm{mg} / \mathrm{L})$ & - & $2,650^{\mathrm{a}}$ & 450 \\
TP $(\mathrm{mg} \mathrm{P} / \mathrm{L})$ & - & $88^{\mathrm{a}}$ & 5 \\
$\mathrm{UV} 254\left(\mathrm{~cm}^{-1)}\right.$ & - & $0.68 \pm 0.02$ & $0.03-0.07$ \\
SUVA $\left(\mathrm{L} \mathrm{mg}^{-1} \mathrm{~m}^{-1}\right)$ & - & $0.71 \pm 0.10$ & No standard \\
Total coliform $(\mathrm{MPN} / 100 \mathrm{ml})$ & - & Not detectable & Not detectable
\end{tabular}

a Analyzed by Mainstream Engineering Co.

\subsubsection{Chlorine Demands and the Formation of Disinfection by-Products}

Chlorine is typically used as a secondary disinfectant because chlorine residual in the system permit the continued inactivation of microbes (Salgot et al. 2006). To retain chlorine residuals in the holding tank at acceptable levels, the treated greywater was chlorinated and the chlorine consumption and the associated DBP formation were investigated for 24 and $48 \mathrm{hrs}$. As shown in Figure 3, the chlorine demand of the treated dishwater was relatively high due to high TOC. 


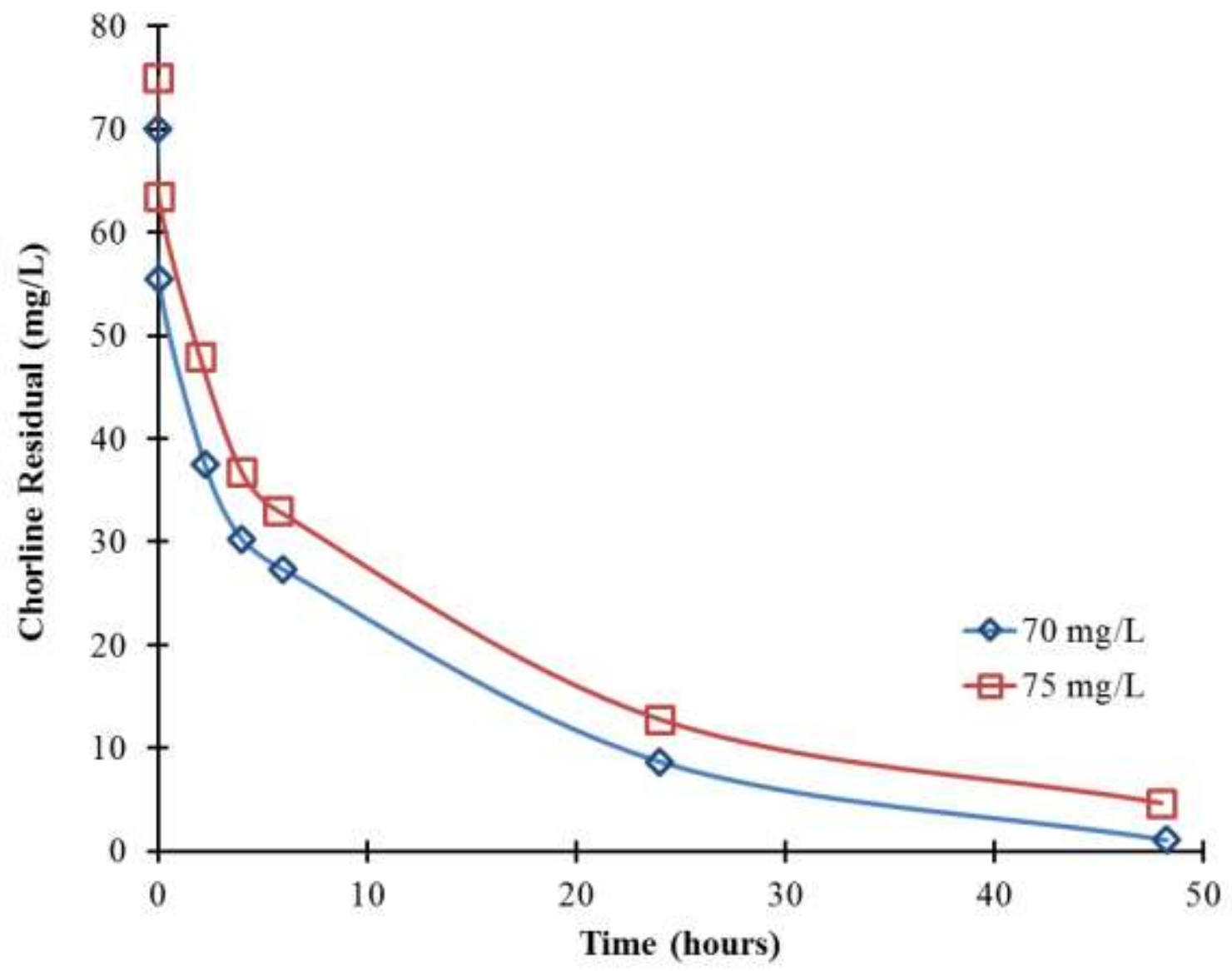

Figure 3. Chlorine demands for treated dishwashing water (pH 9.5) at $32^{\circ} \mathrm{C}$ with chlorine doses of 60, 70, and $75 \mathrm{mg} \mathrm{Cl}_{2} / \mathrm{L}$.

For the treated water, a chlorine dose of $60 \mathrm{mg} \mathrm{Cl} / \mathrm{L}$ resulted in a residual of $2.8 \mathrm{mg}$ $\mathrm{Cl}_{2} / \mathrm{L}$ at 24 hrs but was unable to maintain a concentration above $1 \mathrm{mg} \mathrm{Cl} / \mathrm{L}$ after 48 hours. However, both dosages of 70 and $75 \mathrm{mg} \mathrm{Cl}_{2} / \mathrm{L}$ maintained a concentration above $1 \mathrm{mg} / \mathrm{L}$ after 48 hours (1.1 and $4.7 \mathrm{mg} \mathrm{Cl}_{2} / \mathrm{L}$ of chlorine residual, respectively). As a result, a $60 \mathrm{mg} / \mathrm{L}$ was sufficient for maintaining the recommended chlorine residual in a holding tank with a $24 \mathrm{hrs}$ HRT, but a dosage of 70 or $75 \mathrm{mg} / \mathrm{L}$ would be required at a $48 \mathrm{hrs}$ HRT depending on what factor of safety was decided upon. However, the high chlorine dosages used resulted significant DBP formation because of precursors found in the UF permeate/effluent. 
Most of these organics were small enough to pass through the UF membrane which removes particulates via size exclusion. It is well known that chlorine reacts with NOM to form a broad range of DBP (Jumpatong and Buddhasukh 2003). Table 8 shows the DBP formation after chlorination of the effluents. The species analyzed were chloroform $\left(\mathrm{CHCl}_{3}\right)$, dichlorobromomethane $\left(\mathrm{CHCl}_{2} \mathrm{Br}\right)$, dibromochloromethane $\left(\mathrm{CHClBr}_{2}\right)$, and bromoform $\left(\mathrm{CHBr}_{3}\right)$ for THMs and monochloroacetic acid (MCAA), monobromoacetic acid (MBAA), dichloroacetic acid (DCAA), trichloroacetic acid (TCAA), and dibromoacetic acid (DBAA) for HAAs. Given that U.S. drinking water standard for DBP are $80 \mathrm{ppb}$ for total THMs and $60 \mathrm{ppb}$ for total HAAs (40 CFR Parts 9, 141, and 142), the DBP formation potential was relatively high. As shown in Table 8, after 24 hrs total THMs of 1,789 and 1,685 ppb were generated with chlorine doses of 70 and 75 $\mathrm{mg} \mathrm{Cl} / \mathrm{L}$, respectively. The THMs formed were mostly chloroform $\left(\mathrm{CHCl}_{3}\right)$. Total HAAs were 966 and 1,027 ppb after $24 \mathrm{hrs}$ with chlorine doses of 70 and $75 \mathrm{mg} \mathrm{Cl}_{2} / \mathrm{L}$, respectively.

DBP levels were similar between the different chlorine doses, inferring that organic concentration and reaction time were major factors in the formation of DBP. Even though the water from the system was not designed for ingestion, exposure to these concentrations of DBP via accidental ingestion, dermal adsorption, or inhalation of vaporized DBP could lead to health effects. Extensive research on the health effects of THMs have been published due to the volatile nature of this class of DBP. Even at levels as low as $100 \mathrm{ppb}$, THMs can cause adverse respiratory and allergy related effects (Kabsch-Korbutowicz, 2005). 
Table 8. THM and HAA formation potential of UF/EC treated dishwater

\begin{tabular}{|c|c|c|c|c|c|c|c|c|}
\hline \multirow{6}{*}{ THM } & $\begin{array}{c}\text { Chlorine } \\
\text { dose } \\
\left(\mathrm{mg} \mathrm{Cl}_{2} / \mathrm{L}\right)\end{array}$ & $\begin{array}{l}\text { Time } \\
\text { (hrs) }\end{array}$ & $\begin{array}{l}\mathrm{CHCl}_{3} \\
(\mu \mathrm{g} / \mathrm{L})\end{array}$ & $\begin{array}{c}\mathrm{CHCl}_{2} \mathrm{Br} \\
(\mu \mathrm{g} / \mathrm{L})\end{array}$ & $\begin{array}{c}\mathrm{CHClBr}_{2} \\
(\mu \mathrm{g} / \mathrm{L})\end{array}$ & $\begin{array}{l}\mathrm{CHBr}_{3} \\
(\mu \mathrm{g} / \mathrm{L})\end{array}$ & \multicolumn{2}{|c|}{$\begin{array}{c}\text { Total } \\
(\mu \mathrm{g} / \mathrm{L})\end{array}$} \\
\hline & 60 & 24 & 1562 & 125 & 6.25 & 2.24 & \multicolumn{2}{|c|}{1696} \\
\hline & \multirow{2}{*}{70} & 24 & 1661 & 125 & 2.77 & $<1$ & \multicolumn{2}{|c|}{1789} \\
\hline & & 48 & 2025 & 106 & $<1$ & $<1$ & \multicolumn{2}{|c|}{2132} \\
\hline & \multirow{2}{*}{75} & 24 & 1577 & 106 & 1 & $<1$ & \multirow{2}{*}{\multicolumn{2}{|c|}{$\begin{array}{l}1685 \\
2213\end{array}$}} \\
\hline & & 48 & 2078 & 135 & $<1$ & $<1$ & & \\
\hline \multirow{11}{*}{ HAA } & $\begin{array}{c}\text { Chlorine } \\
\text { dose } \\
\left(\mathrm{mg} \mathrm{Cl}_{2} / \mathrm{L}\right)\end{array}$ & $\begin{array}{l}\text { Time } \\
\text { (hrs) }\end{array}$ & $\begin{array}{c}\text { MCAA } \\
(\mu \mathrm{g} / \mathrm{L})\end{array}$ & $\begin{array}{c}\text { MBAA } \\
(\mu \mathrm{g} / \mathrm{L})\end{array}$ & $\begin{array}{c}\text { DCAA } \\
(\mu \mathrm{g} / \mathrm{L})\end{array}$ & $\begin{array}{l}\text { TCAA } \\
(\mu \mathrm{g} / \mathrm{L})\end{array}$ & $\begin{array}{c}\text { DBAA } \\
(\mu \mathrm{g} / \mathrm{L})\end{array}$ & $\begin{array}{c}\text { Total } \\
(\mu \mathrm{g} / \mathrm{L})\end{array}$ \\
\hline & \multirow{5}{*}{$(2)_{0}$} & 2 & 26.7 & 4 & 286 & 123 & 4.60 & 443 \\
\hline & & 4 & 29.5 & 4 & 321 & 149 & 4.95 & 509 \\
\hline & & 6 & 34.2 & 4 & 361 & 165 & 5.30 & 570 \\
\hline & & 24 & 53.4 & ND & 621 & 285 & 6.50 & 966 \\
\hline & & 48 & 70.2 & ND & 644 & 349 & ND & 1064 \\
\hline & \multirow{5}{*}{75} & 2 & 22.3 & 4 & 223 & 106 & 2.80 & 359 \\
\hline & & 4 & 31.2 & 5 & 335 & 199 & 5.00 & 575 \\
\hline & & 6 & 36.3 & 5 & 365 & 211 & 4.75 & 622 \\
\hline & & 24 & 62.4 & ND & 647 & 317 & ND & 1027 \\
\hline & & 48 & 57.2 & ND & 633 & 282 & ND & 971 \\
\hline
\end{tabular}

Given that chloroform production reached $1,661 \mu \mathrm{g} / \mathrm{L}$ after 24 hours of the exposure to chlorine, a dynamic model software (STELLA, isee systems, Lebanon, NH, USA) was used to predict potential accumulation of chloroform $\left(\mathrm{CHCl}_{3}\right)$ in the air within military field tents. The model was developed based on rate constants derived from experimental data under worst case scenarios (i.e., high temperature water $\left[55^{\circ} \mathrm{C}\right]$, minimal ventilation [0.2 air exchanges per hr], and high doses of chlorine [70 $\mathrm{mg} \mathrm{Cl}_{2} / \mathrm{L}$ every $\left.24 \mathrm{hrs}\right]$ ). Additional details on DBP vaporization are provided in Appendix E. If volatilized, chloroform concentrations spiked at 1.16 ppm shortly after dosing the holding tank with chlorine and fell to $0.47 \mathrm{ppm}$ over the remainder of the day (Appendix E). The U.S. Occupational Safety \& Health Administration (OSHA) requires chloroform concentrations to be below $50 \mathrm{ppm}$, but recommends that the permissible exposure 
limit be reduced to $2 \mathrm{ppm}$ within an hour. Although the model predicts chloroform concentrations will not exceed the OSHA standards, proper ventilation (especially after adding chlorine) will protect the safety of the dishwashing personnel.

\subsubsection{Effects of Surfactants of Microbial Growth}

The effect of surfactants on E. coli disinfection is presented in Figure 4. The data shown represents the mean values of triplicate samples. Among the surfactants tested, the presence of cationic surfactant resulted in more than 6- $\log _{10}$ reduction within 5 min (data not shown); however, cationic surfactants are generally not used in dishwashing detergents. The control test (i.e., treated water without detergent or surfactant) showed inhibited microbial growth which is likely linked to zinc residuals during EC. The greywater with the standard issued detergent (NSN 7930-00-281-4731, NuGentec, Emeryville, California) effectively reduced the E. coli concentration in the synthetic dishwater along with the anionic and nonionic surfactants. The presence of surfactants showed $97.8-99.8 \%$ reduction of $E$. coli within $1 \mathrm{hr}$ and the rate of microbial decay was 2.5 times faster compared to the water without any detergent or surfactant. With the exception of the cationic surfactant, the effect of surfactant type on the survival of $E$. coli was insignificant in this batch test. All surfactants at a concentration of $0.05 \mathrm{~N}$ significantly reduced E. coli concentrations within the $4 \mathrm{hrs}$ experiment (the HRT of the storage tank is approximately 1 day), indicating that the detergent used can provide an additional barrier against microbial growth. The $\mathrm{pH}$ for surfactant tests were in the range of 6.8-8.6, which meet typical greywater reuse standards. 


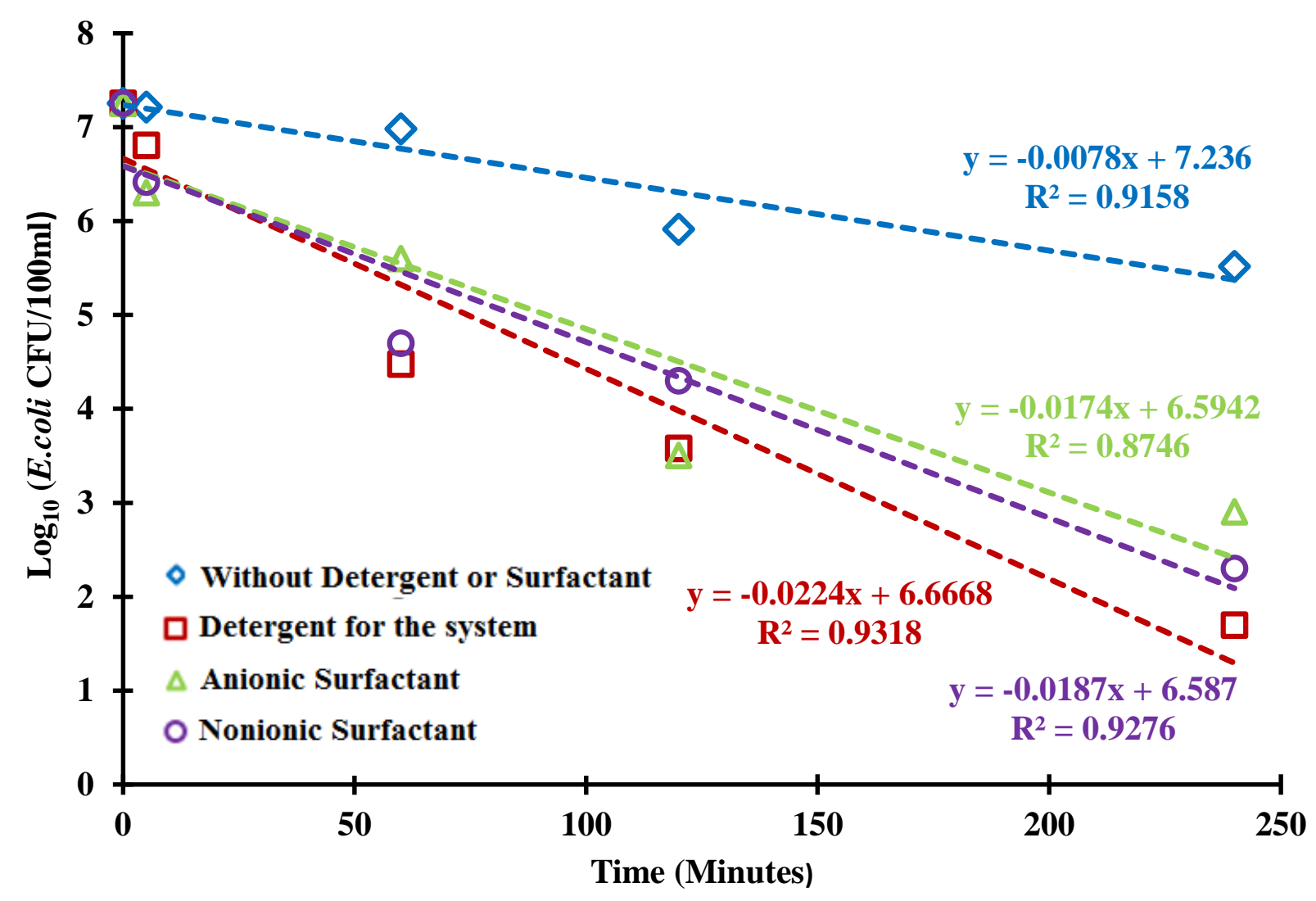

Figure 4. Effect of surfactants on E. coli decay.

\subsubsection{Quantitative Microbial Risk Assessment}

The results of the QMRA are displayed in Figure 5. If the reclaimed dishwashing water is recycled for dishwashing with the assumption of $1 \mathrm{~mL}$ ingestion of this water by accident, the concentrations of norovirus, Salmonella spp., and E. coli O157:H7 in the holding tank should not exceed $8.7,0.92$, and $8.2 \times 10^{-3}$ per $\mathrm{mL}$, respectively. If the water is reused for showering with the assumption of accidental ingestion of $1.9 \mathrm{~mL}$ per day, the concentrations of norovirus, Salmonella spp., and E. coli O157:H7 should be no greater than $5.4 \times 10^{3}, 576$, and 5.1 per mL, respectively. With further treatment to remove chemical contaminants and improve aesthetics, the reclaimed dishwashing water could even be reused for direct potable use, if concentrations 
remained below $2.9 \times 10^{-3}$ noroviruses per $\mathrm{mL}, 3.1 \times 10^{-4}$ Salmonella per $\mathrm{mL}$, and $2.7 \times 10^{-6}$ E. coli O157:H7 per mL.

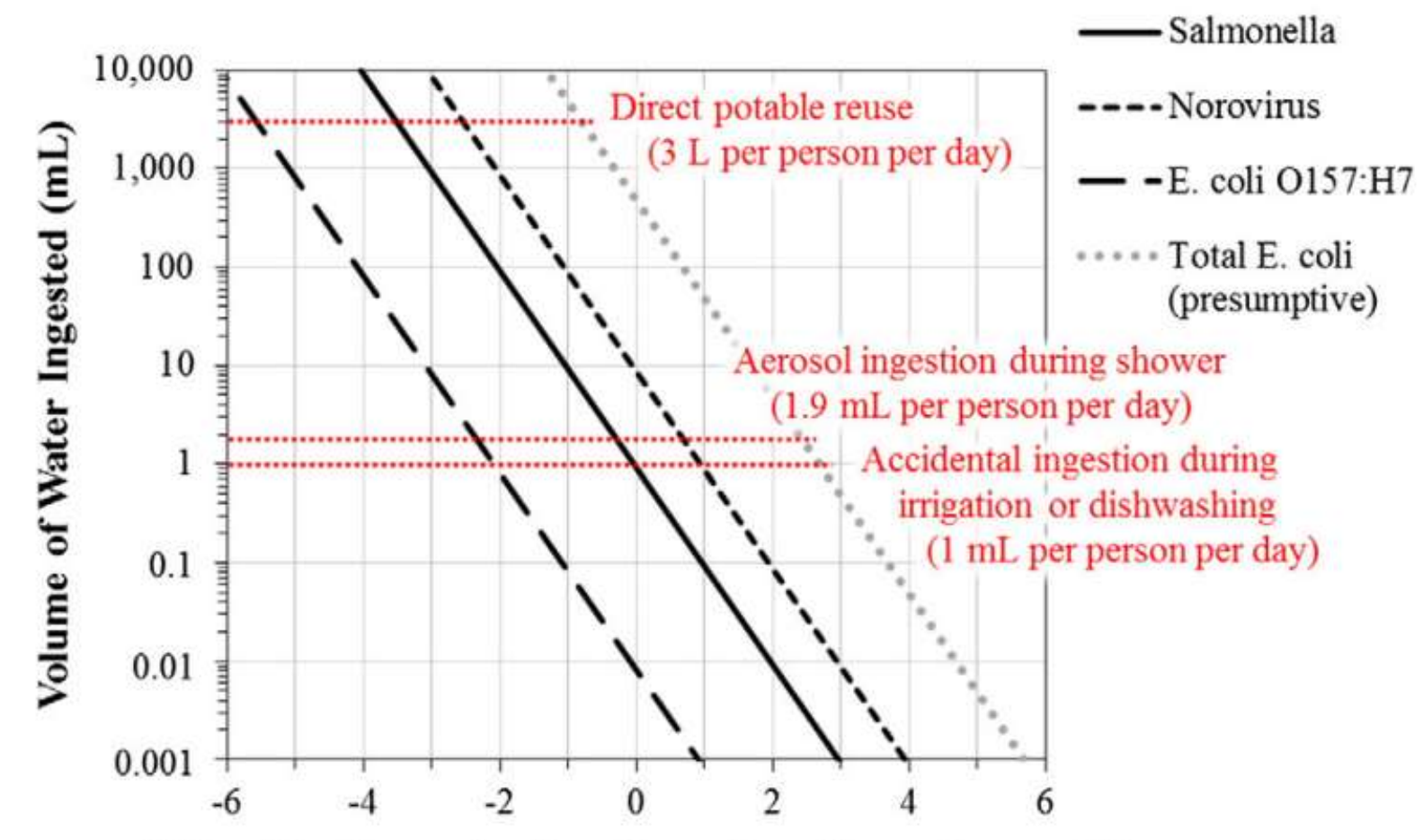

Tolerable Concentration $\left(\log _{10}\right.$-transformed per $\mathrm{mL}$ )

Figure 5. Maximum tolerable concentration of reference pathogens vs. volume of recycled dishwater ingested (accidentally or intentionally) per person per day, based on a limit of one illness per 50,000 exposures, assuming that exposure occurs daily.

Routine monitoring for E. coli O157:H7, Salmonella, and human norovirus in water samples may not be practical or economically feasible in military field settings. However, as evidenced by Figure 5, the microbial risk posed by E. coli O157:H7 is greater than the risks posed by Salmonella and human norovirus. It is not typical to monitor concentrations of individual strains of $E$. coli in the field, therefore, a ratio of pathogenic $E$. coli strains to total $E$. coli will be used to roughly estimate the maximum recommended concentration of total E. coli in dishwashing water, which can be used to establish water reuse guidelines for this particular 
context. Currently, there is no accepted value for such a ratio in dishwashing water. Thus, the ratio of $E$. coli $O 157: H 7$ to total $E$. coli in ground beef may be the closest approximation to the ratio of pathogenic $E$. coli to total $E$. coli in dishwashing water.

The ratio of $E$. coli $O 157: H 7$ to total $E$. coli in ground beef (and the assumed ratio in dishwashing water) would be between $2.3 \times 10^{-7}$ and $1.7 \times 10^{-5}$ (refer to calculations in the appendix F). Using the higher of the two estimated ratios, the presumptive concentration of total E. coli in reclaimed dishwashing water would be five orders of magnitude greater than the concentration of pathogenic E. coli. Since the ratio of pathogenic E. coli to total E. coli may be even greater than assumed here, it would be sensible to use a factor of safety equal to one additional order of magnitude in proposed maximum concentrations.

Since the tolerable concentration of total $E$. coli is $\sim 500$ per $\mathrm{mL}$ according to the results of the QMRA (see Figure 5), the recommended concentration of total E. coli in reclaimed dishwashing water is 50 per mL. Even without chlorination, this should be easily achieved with the treatment system described in this thesis, especially given the anticipated decay of E. coli in the presence of dishwashing surfactants in the holding tank (Figure 4). It is important to note that coliform bacteria (such as E. coli) may not always be the most adequate indicators of contamination by all foodborne pathogens in treated dishwashing water (Sheikh 2010), and more research may be needed to determine the typical concentrations of foodborne pathogens in dishwashing water, as well as the fate and transport of other pathogens (such as viruses) in the treatment system. 


\section{CHAPTER FOUR: DEVELOPMENT OF DISHWATER RECYCLING STANDARDS}

\subsection{Recommended Water Quality Standards for Dishwashing Water Recycling}

There are many physical, chemical, and biological water quality parameters for evaluating greywater treatment (Mollah et al. 2004). While some water parameters (e.g., pH and turbidity) can easily be monitored using simple measurements (e.g., potable $\mathrm{pH}$ meter and turbidity meter); others, like BOD, COD, and TOC, are time-consuming, complicated, and not applicable for field use. Field testing methods need to be rapid and simple while also providing accurate information on water quality. Turbidity, $\mathrm{pH}$, and $\mathrm{UV}_{254}$ were selected as indispensable water quality parameters for field use of dishwasher recycling based on parameters used in TB MED 577 and due to the effectiveness of $U_{254}$ as a surrogate for organic monitoring (Potter and Wimsatt 2012; Reckhow et al. 1990).

If the treated dishwashing water is used for dishwashing, irrigation, or showering, it is recommended that maximum $E$. coli concentrations should not exceed 50 per mL. As demonstrated by QMRA (Figure 5), maximum norovirus concentrations should also not exceed $\sim 1$ per $\mathrm{mL}$, and maximum Salmonella concentrations should not exceed $\sim 0.1$ per $\mathrm{mL}$ (using a factor of safety of one $\log 10$ unit). Reducing the concentration of these pathogens beyond these recommended levels would require additional expenses, and may not be necessary to ensure a level of health protection that is suitable for individuals in this setting. Concentrations of waterand food-borne pathogens, including bacteria, protozoa and viruses, should be sufficiently removed by ultrafiltration and electro-coagulation (Blyth et al. 2007).

A chlorine residual of at least $1.0 \mathrm{mg} \mathrm{Cl} / 2$ is often recommended in water reuse guidelines to maintain microbial inactivation in the water reuse systems (e.g., prevent bacterial 
growth in reclaimed water holding tanks); however, the use of chlorine in this context may not be necessary unless bacterial growth is observed because it may cause unintended health risks (due to the formation of DBP) and unnecessary costs. If chlorine is used, it is recommended to implement further treatment strategies for the removal of organics to prevent DBP formation.

Currently, TB MED 577 sets guidelines for water quality during field operation but lacks regulation of organic contaminates (U.S. Army 2010). On the other hand, U.S. state and federal agencies carefully monitor and regulate organic pollutants in drinking and wastewater treatment because of the contribution of organic compounds to microbial growth, oxygen consumption, and chlorine residual depletion (USEPA 2012). The gap between water quality standards from state regulations and TB MED 577 is likely due to the difficulty in monitoring organic contaminates in field operation. It is recommended that $\mathrm{BOD}_{5}$ be monitored and maintained at values of below $30 \mathrm{mg} / \mathrm{L}$ for dishwater reuse which is the same limit set by the U.S. EPA Secondary Standard as well as other state regulations for greywater reuse. While $\mathrm{BOD}_{5}$ measurements may be unsuitable for field operation, several optical techniques have been developed for quick and simple monitoring of organic contaminates (e.g., $\mathrm{UV}_{280}, \mathrm{UV}_{254}$, color 436 , and color 400 ) (Uyguner et al. 2011). $\mathrm{UV}_{254}$ has gained significant attention because of its strong correlation with DBP formation potential (Becker and Wattier 1985; Pifer and Fairey 2014), thus enabling the use of $\mathrm{UV}_{254}$ for chlorinated water systems. It is expected that the parameter can also be useful for monitoring organics and DBP in military operations with the aid of commercially available spectroscopy devices. Currently, TB MED 577 has no regulation on the DBP formation from chlorine disinfection; but, it is recommended to monitor the organic contaminants for public safety. 
Table 9. Developed water quality standard of the dishwashing water recycling system for military use

\begin{tabular}{cc}
\hline Parameter & Recommended water standard \\
\hline $\mathrm{pH}$ & $6-9$ \\
Turbidity & $<1 \mathrm{NTU}$ \\
$\mathrm{UV}_{254}$ & Surrogate $^{\mathrm{a}}$ for organics $\left(\mathrm{e} . \mathrm{g} ., \mathrm{BOD}_{5}\right.$ below $\left.30 \mathrm{mg} / \mathrm{L}\right)$ \\
E. coli & $<50 \mathrm{cfu}^{\mathrm{s}} \mathrm{mL}^{\mathrm{b}}$ \\
\hline
\end{tabular}

${ }^{\mathrm{a}}$ The correlation with $\mathrm{BOD}_{5}$ for the dishwashing water to be recycled needs to be evaluated in the laboratory and calibration curves should be constructed before the use of $\mathrm{UV}_{254}$ in field.

${ }^{\mathrm{b}}$ This recommended standard is proposed for reuse of recycled dishwashing water for dishwashing in military field settings

Measurement of $\mathrm{UV}_{254}$ can be a useful tool for providing a simple monitoring parameter for water quality of treated dishwater during field operation. Dishwater quality varies from meal to meal, which could pose a problem for using $\mathrm{UV}_{254}$ for organic regulation. To employ $\mathrm{UV}_{254}$ as a parameter of organic contaminants, the relationship between $\mathrm{UV}_{254}$ and other organic parameters needs to be further investigated. Turbidity and $\mathrm{pH}$ are easily measured parameters that can also provide information on the effectiveness of the treatment.

Based on the results and discussion above, a final set of dishwashing water reuse standards for field analysis was proposed as follows (Table 6): $\mathrm{pH} 6-9$, turbidity $<1 \mathrm{NTU}$, and $E$. coli $<50 \mathrm{cfu} \mathrm{mL}^{-1}$.

\subsection{Environmental Discharge Considerations}

For environmental discharge in the U.S., the dishwater recycling system requires a $\mathrm{BOD}_{5}$ less than $30 \mathrm{mg} / \mathrm{L}$ and $\mathrm{pH}$ between 6 and 9 . These standards could also be adopted for military dishwater recycling. This practice would also be beneficial for DBP reduction if chlorine disinfection is used. . 


\section{CHAPTER FIVE: CONCLUSIONS}

A preliminary water reuse standard for dishwashing water was developed based on federal, state, and military regulations for non-potable water and on the evaluation of an existing electrocoagulation/ultrafiltration dishwater recycling treatment device. The specific set of dishwashing water reuse standards for field analysis (simple, but accurate) has then been finalized as follows: pH 6-9, turbidity $<1$ NTU, $\mathrm{UV}_{254}$, and E. coli $<50 \mathrm{cfu} \mathrm{mL}^{-1}$. QMRA established that $E$. coli concentrations less than $50 \mathrm{cfu} \mathrm{mL}^{-1}$ will reduce risk of illness to less than 1 in 50,000 exposures, which is two orders of magnitude less than the current estimated disease incidence for military field personnel.

The developed specific water standard is the first for dishwashing water reuse and will be expected to maintain water quality that is safe for field operations, but not so stringent as to induce undue design complexity, cost, and operational/maintenance requirements. In addition, the parameters can be monitored using simple equipment in a field setting with only modest training requirements and real-time or rapid sample turn-around. The standard is expected to provide the military with a simple, compact, maintainable, integrated system to reliably process water quality data with variable mixtures of food, oil, and detergents from dishwashing water. This study may also prove useful in future development of civilian dishwashing guidelines. 


\section{APPENDIX A: DETERGENT ANALYSIS}




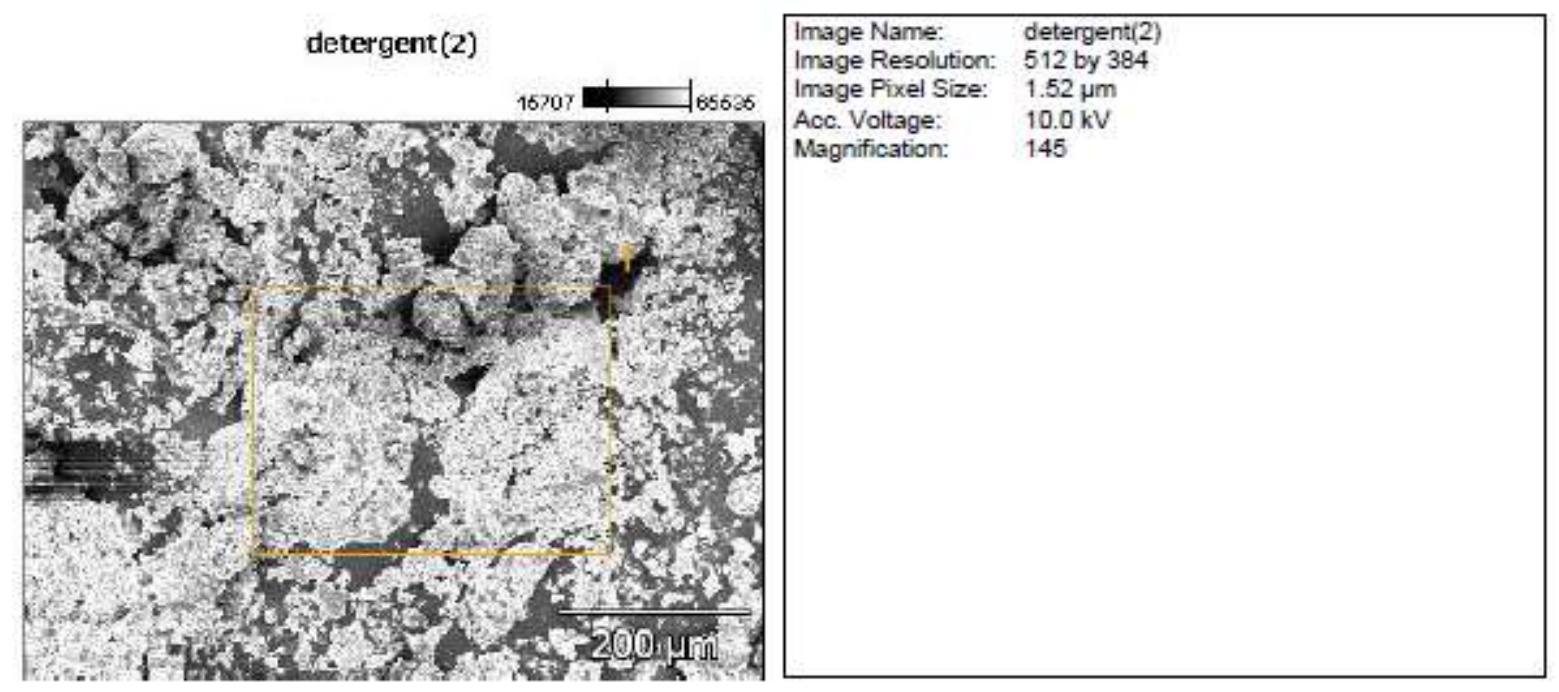

Full scale counts: 459

detergent(2)_pt1

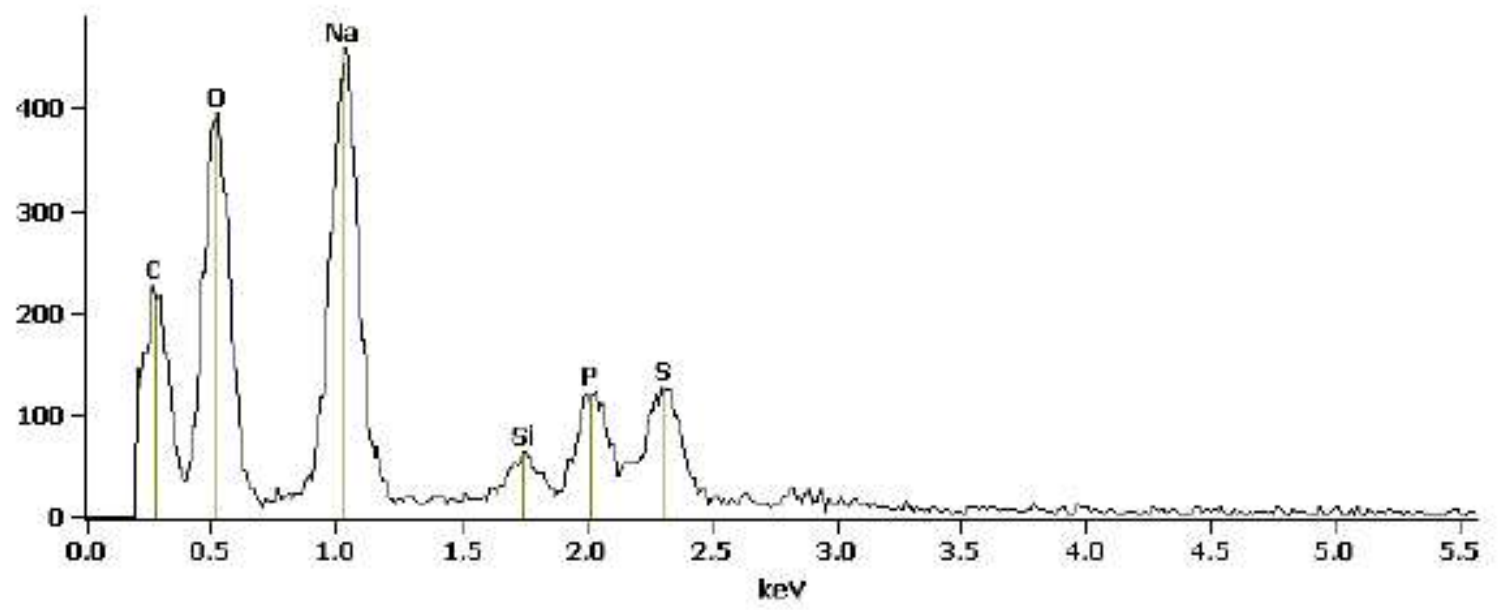


Weight \%

\begin{tabular}{|c|c|c|c|c|c|c|}
\hline & $\mathbf{C}-\mathbf{K}$ & $O-K$ & $\mathrm{Na}-\mathrm{K}$ & Si-k & $\mathbf{P}-\boldsymbol{K}$ & S-K \\
\hline detergent(2)_pt1 & 35.19 & 24.20 & 20.45 & 2.69 & 8.28 & 9.19 \\
\hline
\end{tabular}

Weight \% Error ( $+/-1$ Sigma)

\begin{tabular}{|c|c|c|c|c|c|c|}
\hline & C-K & $O-K$ & $\mathrm{Na}-\mathrm{K}$ & $S-K$ & $\mathbf{P}-\mathbf{K}$ & $S-K$ \\
\hline detergent(2)_pt1 & $+/-1.54$ & $+/-1.28$ & $+/-0.69$ & $+/-0.19$ & $+/-0.38$ & $+1-0.72$ \\
\hline \multicolumn{7}{|l|}{ Atom \% } \\
\hline & C-K & $O-K$ & $\mathbf{N a - K}$ & Si-K & P-K & S-K \\
\hline detergent(2)_pt1 & 48.98 & 25.28 & 14.87 & 1.60 & 4.47 & 4.79 \\
\hline \multicolumn{7}{|c|}{ Atom \% Error (+/- 1 Sigma) } \\
\hline & $\mathbf{C}-\mathbf{K}$ & $O-K$ & $\mathrm{Na}-\mathrm{K}$ & si-k & P-K & $S-K$ \\
\hline detergent(2)_pt1 & $+/-2.14$ & $+/-1.34$ & $+/-0.50$ & $+/-0.11$ & $+/-0.20$ & $+1-0.38$ \\
\hline
\end{tabular}


APPENDIX B: ADDITIONAL WATER REUSE STANDARDS 
Table B1. Selected Greywater Reuse Standards

\begin{tabular}{|c|c|c|c|c|c|c|c|}
\hline Application & Agency & $\mathbf{p H}$ & $\begin{array}{l}\text { Turbidity } \\
\text { (NTU) }\end{array}$ & BOD & F. coli & $\begin{array}{c}\begin{array}{c}\text { Free } \\
\text { chlorine } \\
\left(\mathrm{mgCl}_{2} / \mathrm{L}\right)\end{array} \\
\end{array}$ & Other \\
\hline \multirow{15}{*}{$\begin{array}{c}\text { Urban- } \\
\text { Unrestricted }\end{array}$} & $\begin{array}{l}\text { Arizona- } \\
\text { Class A }\end{array}$ & - & $\begin{array}{l}<2(24 \mathrm{hr}) \\
<5(\text { Max })\end{array}$ & - & $\begin{array}{c}\text { none/100ml }{ }^{\mathrm{b}} \\
\text { 3/100ml- Max }\end{array}$ & - & $\begin{array}{l}\text { Nitrogen } \\
<10 \mathrm{mg} / \mathrm{L}\end{array}$ \\
\hline & $\begin{array}{l}\text { California- } \\
\text { Tertiary }\end{array}$ & - & $\begin{array}{l}<2(24 \mathrm{hr}) \\
<10(\mathrm{Max})\end{array}$ & - & $\begin{array}{c}2.2 / 100 \mathrm{ml}^{\mathrm{a}} \\
23 / 100 \mathrm{ml} \text { (Max) }\end{array}$ & - & - \\
\hline & Florida & - & $\begin{array}{c}<2-2.5 \\
\text { (continuous) }\end{array}$ & $\begin{array}{l}\text { CBOD } \\
<20 \mathrm{mg} / \mathrm{L}^{\mathrm{a}}\end{array}$ & $\begin{array}{l}75 \% \text { samples } \\
\text { below detection } \\
25 / 100 \mathrm{ml} \text { (Max) }\end{array}$ & $\begin{array}{l}>1 \text { for } \\
15 \mathrm{~min}\end{array}$ & - \\
\hline & Hawaii-R1 & - & $\begin{array}{l}<2(95 \%) \\
<10(\text { Max })\end{array}$ & $<30 \mathrm{mg} / \mathrm{L}$ & $2.2 / 100 \mathrm{ml}^{\mathrm{a}}$ & $\begin{array}{c}>5(90 \\
\min )\end{array}$ & - \\
\hline & $\begin{array}{l}\text { Nevada- } \\
\text { Category A }\end{array}$ & - & & $<30 \mathrm{mg} / \mathrm{L}^{\mathrm{c}}$ & $\begin{array}{c}2.2 / 100 \mathrm{ml}^{\mathrm{c}} \\
23 / 100 \mathrm{ml}(\operatorname{Max})\end{array}$ & - & - \\
\hline & $\begin{array}{l}\text { New Jersey- } \\
\text { Type I }\end{array}$ & - & $<2(\operatorname{Max})$ & - & $\begin{array}{c}2.2 / 100 \mathrm{ml}^{\mathrm{a}} \\
14 / 100 \mathrm{ml}(\mathrm{Max})\end{array}$ & $\begin{array}{l}>1(15 \\
\min )\end{array}$ & $\begin{array}{l}\text { Nitrogen } \\
<10 \mathrm{mg} / \mathrm{L}\end{array}$ \\
\hline & $\begin{array}{l}\text { North } \\
\text { Carolina- } \\
\text { Tier } 1\end{array}$ & - & $<10(\operatorname{Max})$ & $\begin{array}{c}<10 \mathrm{mg} / \mathrm{L}^{\mathrm{c}} \\
<15 \mathrm{mg} / \mathrm{L} \\
(\mathrm{Max})\end{array}$ & $\begin{array}{c}14 / 100 \mathrm{ml}^{\mathrm{c}} \\
25 / 100 \mathrm{ml}(\mathrm{Max})\end{array}$ & - & - \\
\hline & $\begin{array}{c}\text { Texas- Type } \\
\text { I }\end{array}$ & - & $<3$ & $<5 \mathrm{mg} / \mathrm{l}$ & $\begin{array}{c}20 / 100 \mathrm{ml}^{\mathrm{c}} \\
75 / 100 \mathrm{ml} \\
(\operatorname{Max})\end{array}$ & - & - \\
\hline & Oregon & - & - & $<10 \mathrm{mg} / \mathrm{L}$ & $2.2 / 100 \mathrm{ml}^{\mathrm{c}}$ & - & - \\
\hline & $\begin{array}{l}\text { Virginia- } \\
\text { Level } 1\end{array}$ & - & $<2^{\mathrm{b}}$ & $<10 \mathrm{mg} / \mathrm{L}^{\mathrm{c}}$ & $14 / 100 \mathrm{ml}^{\mathrm{c}}$ & - & - \\
\hline & $\begin{array}{l}\text { Washington- } \\
\text { Class A }\end{array}$ & - & $\begin{array}{c}<2^{\mathrm{b}} \\
<5(\operatorname{Max})\end{array}$ & $<30 \mathrm{mg} / \mathrm{L}$ & $\begin{array}{c}2.2 / 100 \mathrm{ml}^{\mathrm{a}} \\
23 / 100 \mathrm{ml}-\mathrm{Max}\end{array}$ & - & - \\
\hline & $\begin{array}{c}\text { EPA- } \\
\text { Unrestricted }\end{array}$ & $\begin{array}{c}6.0 \\
- \\
9.0\end{array}$ & $<2$ & $<10 \mathrm{mg} / \mathrm{l}$ & None/ 100ml & 1 & - \\
\hline & $\begin{array}{l}\text { NSF/ANSI } \\
350 \text { Class R }\end{array}$ & $\begin{array}{c}6.0 \\
- \\
9.0\end{array}$ & $\begin{array}{c}<5 \\
10-\operatorname{Max}\end{array}$ & $\begin{array}{l}<10 \mathrm{mg} / 1 \\
25 \mathrm{mg} / \mathrm{l} \\
(\mathrm{Max})\end{array}$ & $\begin{array}{c}\text { E.Coli-14/ } \\
100 \mathrm{ml} \\
240 \text { (Max) }\end{array}$ & $\begin{array}{l}>0.5 \\
<2.5\end{array}$ & - \\
\hline & $\begin{array}{l}\text { NSF/ANSI } \\
350 \text { Class C }\end{array}$ & $\begin{array}{c}6.0 \\
- \\
9.0\end{array}$ & $\begin{array}{c}<5 \\
10-\operatorname{Max}\end{array}$ & $\begin{array}{l}<10 \mathrm{mg} / \mathrm{l} \\
25 \mathrm{mg} / \mathrm{l} \\
(\mathrm{Max})\end{array}$ & $\begin{array}{c}\text { E. Coli- } 2.2 / \\
100 \mathrm{ml}^{*} \\
200(\mathrm{Max})\end{array}$ & $\begin{array}{c}>0.5 \mathrm{mg} / \\
\mathrm{L} \\
<2.5\end{array}$ & - \\
\hline & $\begin{array}{c}\text { TB MED } \\
577- \\
\text { Unrestricted }\end{array}$ & $\begin{array}{l}6.5 \\
-10\end{array}$ & $\begin{array}{c}<10 \\
<1 \text { (filtered) }\end{array}$ & - & $\begin{array}{c}\text { E. Coli- None/ } \\
100 \mathrm{ml} \\
10(\mathrm{Max})\end{array}$ & $\begin{array}{l}1(30 \\
\min )\end{array}$ & - \\
\hline \multirow{4}{*}{$\begin{array}{c}\text { Urban- } \\
\text { Restricted }\end{array}$} & $\begin{array}{l}\text { Arizona- } \\
\text { Class B }\end{array}$ & - & - & - & $\begin{array}{l}\text { 200/100ml } \\
\text { 800/100ml } \\
\text { (Max) }\end{array}$ & - & $\begin{array}{c}\text { Nitrogen } \\
< \\
10 \mathrm{mg} / \mathrm{L}\end{array}$ \\
\hline & $\begin{array}{l}\text { California- } \\
\text { Tertiary }\end{array}$ & - & - & - & $\begin{array}{c}23 / 100 \mathrm{ml}^{\mathrm{a}} \\
240 / 100 \mathrm{ml}-\text { Max }\end{array}$ & - & - \\
\hline & Florida $^{1}$ & - & - & - & - & - & - \\
\hline & Hawaii-R2 & - & - & $\begin{array}{c}30 \mathrm{mg} / \mathrm{L} \text { or } \\
60 \mathrm{mg} / \mathrm{L} \\
\text { depending of } \\
\text { design }\end{array}$ & $\begin{array}{c}23 / 100 \mathrm{ml}^{\mathrm{a}} \\
200 / 100 \mathrm{ml} \\
(\max )\end{array}$ & $\begin{array}{c}>5(90 \\
\min )\end{array}$ & - \\
\hline
\end{tabular}

a. Weekly Average, ${ }^{\text {b. }}$ Daily Average, ${ }^{\text {C. }}$ Monthly Average 
Table B1 continued

\begin{tabular}{|c|c|c|c|c|c|c|c|}
\hline Application & Agency & pH & $\begin{array}{c}\text { Turbidity } \\
\text { (NTU) }\end{array}$ & BOD $_{5}$ & F. coli & $\begin{array}{c}\text { Free } \\
\text { chlorine } \\
\left(\mathrm{mgCl}_{2} / \mathrm{L}\right)\end{array}$ & Other \\
\hline \multirow{8}{*}{$\begin{array}{c}\text { Urban- } \\
\text { Restricted }\end{array}$} & $\begin{array}{c}\text { Nevada- } \\
\text { Category B }\end{array}$ & - & - & $30 \mathrm{mg} / \mathrm{L}^{\mathrm{b}}$ & $\begin{array}{c}2.2 / 100 \mathrm{ml}^{\mathrm{b}} \\
23 / 100 \mathrm{ml}(\mathrm{Max})\end{array}$ & (1) & - \\
\hline & $\begin{array}{l}\text { New Jersey- } \\
\text { Type II }\end{array}$ & - & - & - & $\begin{array}{c}200 / 100 \mathrm{ml}^{\mathrm{c}} \\
400 / 100 \mathrm{ml} \\
(\mathrm{Max})\end{array}$ & $\begin{array}{c}>1(15 \\
\min )\end{array}$ & $\begin{array}{c}\text { Nitrogen } \\
< \\
10 \mathrm{mg} / \mathrm{L}\end{array}$ \\
\hline & $\begin{array}{l}\text { North } \\
\text { Carolina- } \\
\text { Tier } 1\end{array}$ & - & $<10(\max )$ & $\begin{array}{c}<10 \mathrm{mg} / \mathrm{L}^{\mathrm{c}} \\
<15 \mathrm{mg} / \mathrm{L} \\
(\max )\end{array}$ & $\begin{array}{c}\text { 14/100ml } \mathrm{ml}^{\mathrm{c}} \\
25 / 100 \mathrm{ml}(\mathrm{Max})\end{array}$ & - & - \\
\hline & $\begin{array}{c}\text { Texas- Type } \\
\text { II }\end{array}$ & - & - & $\begin{array}{l}<20 \mathrm{mg} / 1 \\
\text { without pond } \\
\text { system }\end{array}$ & $\begin{array}{l}200 / 100 \mathrm{ml}^{\mathrm{c}} \\
800 / 100 \mathrm{ml} \\
(\mathrm{Max})\end{array}$ & - & - \\
\hline & $\begin{array}{l}\text { Virginia- } \\
\text { Level } 2\end{array}$ & - & - & $\begin{array}{c}<30 \mathrm{mg} / \mathrm{L}^{\mathrm{c}} \\
<45 \mathrm{mg} / \mathrm{L} \\
(\max )\end{array}$ & $200 / 100 \mathrm{ml}^{\mathrm{c}}$ & - & - \\
\hline & $\begin{array}{l}\text { Washington- } \\
\text { Class C }\end{array}$ & - & - & $<30 \mathrm{mg} / \mathrm{L}$ & $\begin{array}{c}23 / 100 \mathrm{ml}^{\mathrm{a}} \\
240 / 100 \mathrm{ml} \\
(\mathrm{Max})\end{array}$ & $\begin{array}{c}>1(30 \\
\min )\end{array}$ & - \\
\hline & $\begin{array}{c}\text { EPA- } \\
\text { Restricted }\end{array}$ & $\begin{array}{c}6.0 \\
- \\
9.0\end{array}$ & - & - & $<200 / 100 \mathrm{ml}$ & - & - \\
\hline & $\begin{array}{l}\text { TB MED } \\
577- \\
\text { Restricted } \\
\end{array}$ & - & $\begin{array}{c}<5^{\mathrm{a}} \\
<10(\operatorname{Max})\end{array}$ & - & $\begin{array}{c}\text { E. Coli- 150/ } \\
100 \mathrm{ml} \\
600(\mathrm{Max}) \\
\end{array}$ & - & - \\
\hline \multirow{3}{*}{$\begin{array}{l}\text { Groundwater } \\
\text { Recharge }\end{array}$} & Florida & - & - & $\begin{array}{c}\mathrm{CBOD} \\
<30 \mathrm{mg} / \mathrm{L}^{\mathrm{c}} \\
<45 \mathrm{mg} / \mathrm{L}^{\mathrm{a}} \\
<60 \mathrm{mg} / \mathrm{L} \\
(\max )\end{array}$ & $\begin{array}{c}200 / 100 \mathrm{ml} \\
800 / 100(\max )\end{array}$ & $\begin{array}{c}>0.5 \\
(15 \mathrm{~min})\end{array}$ & $\begin{array}{l}\text { Nitrate } \\
<12 \mathrm{mg} / \mathrm{l}\end{array}$ \\
\hline & Washington & - & $\begin{array}{c}<2^{\mathrm{b}} \\
<5(\operatorname{Max})\end{array}$ & $<5 \mathrm{mg} / \mathrm{L}$ & $\begin{array}{c}2.2 / 100 \mathrm{ml}^{\mathrm{a}} \\
23 / 100 \mathrm{ml}-\mathrm{Max}\end{array}$ & $\begin{array}{c}>1(30 \\
\min )\end{array}$ & - \\
\hline & $\begin{array}{c}\text { EPA- } \\
\text { Recharge }\end{array}$ & $\begin{array}{c}6.5 \\
- \\
8.5\end{array}$ & $<2$ & - & - & 1 & - \\
\hline Potable & $\begin{array}{c}\text { TB MED } 577 \\
\text { (Short term } \\
\text { Potable) }\end{array}$ & $\begin{array}{c}5.0 \\
- \\
9.0\end{array}$ & $<1$ & - & None/ $100 \mathrm{ml}$ & - & \\
\hline
\end{tabular}

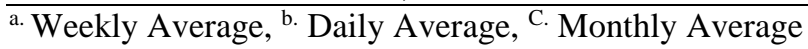

Source: U.S. EPA's Guidelines for Water Reuse 
APPENDIX C: THM ANALYSIS QUALITY ASSURANCE/QUALITY CONTROL 
The QA/QC results for this study are presented in Tables C1 and C2. Sample duplicates are within the acceptable variation range of $10 \%$ RSD. The sample spikes were assessed by \% Recovery and the acceptable range is $80-120 \%$ Recovery. All reported analyses are within this range. The haloacetic acid analysis was conducted by an external laboratory and analytical QA/QC was not provided. However, the experimental dupe for samples dosed with 70 and $75 \mathrm{mg} / \mathrm{L}$ and incubated at 24 hours showed a \%RSD of $9 \%$ and $8 \%$ total haloacetic acids, respectively. This is still within the acceptable $10 \%$ limit.

\section{Table C1. QA/QC Checks: Chlorine Residual}

\begin{tabular}{|c|c|c|c|c|}
\hline \multirow[b]{2}{*}{ QA/QC } & \multirow{2}{*}{$\begin{array}{c}\text { Sample ID } \\
\text { Chlorine Dose (mg/L) @ } \\
\text { Time (h) }\end{array}$} & \multicolumn{2}{|c|}{ Chloride Residual (mg/L) } & \multirow[b]{2}{*}{$\%$ RSD } \\
\hline & & Sample 1 & Sample 2 & \\
\hline Analytical & $\begin{array}{c}60 @ 24 \\
70 @ 24 \\
75 @ 24 \text { Dupe }\end{array}$ & $\begin{array}{c}2.8 \\
8.7 \\
13.0\end{array}$ & $\begin{array}{c}2.8 \\
8.4 \\
13.0\end{array}$ & $\begin{array}{c}1 \\
3 \\
<1\end{array}$ \\
\hline Experimental & $\begin{array}{c}70 @ 0.03 \\
75 @ 24\end{array}$ & $\begin{array}{l}55.5 \\
12.8\end{array}$ & $\begin{array}{l}60.0 \\
13.0\end{array}$ & $\begin{array}{l}7 \\
1\end{array}$ \\
\hline
\end{tabular}


Table C2. QA/QC Checks: Trihalomethanes

\begin{tabular}{|c|c|c|c|c|c|c|c|}
\hline \multirow{2}{*}{ Sample } & \multirow{2}{*}{$\begin{array}{c}\text { Chlorine } \\
\text { Dose } \\
(\mathrm{mg} / \mathrm{L})\end{array}$} & \multirow{2}{*}{$\begin{array}{l}\text { Incubation } \\
\text { Time (hr) }\end{array}$} & \multirow{2}{*}{ Dilution } & \multicolumn{4}{|c|}{ THM $(\mu \mathrm{g} / \mathrm{L}) *$} \\
\hline & & & & $\mathrm{CHCl}_{3}$ & $\mathrm{CHCl}_{2} \mathrm{Br}$ & $\mathrm{CHClBr}_{2}$ & $\mathrm{CHBr}_{3}$ \\
\hline ANALYTICAL & & & & & & & \\
\hline Chlorinated Dishwater & 70 & 24 & $1: 10$ & 166.09 & 12.51 & $<1$ & $<1$ \\
\hline Dupe & & & & 170.59 & 12.16 & $<1$ & $<1$ \\
\hline Spike $(+30 \mu \mathrm{g} / \mathrm{L})$ & & & & 191.36 & 44.80 & 35.14 & 30.55 \\
\hline$\% \mathrm{RSD}$ & & & & 2 & 3 & $<1$ & $<1$ \\
\hline \%Recovery & & & & 84 & 108 & 116 & 102 \\
\hline Chlorinated Dishwater & 60 & 24 & $1: 20$ & 76.09 & 5.01 & $<1$ & $<1$ \\
\hline Dupe & & & & 76.40 & 5.26 & $<1$ & $<1$ \\
\hline Spike $(+50 \mu \mathrm{g} / \mathrm{L})$ & & & & 123.88 & 59.85 & 56.70 & 50.32 \\
\hline$\%$ RSD & & & & $<1$ & 4 & $<1$ & $<1$ \\
\hline \%Recovery & & & & 96 & 110 & 113 & 101 \\
\hline EXPERIMENTAL & & & & & & & \\
\hline Chlorinated Dishwater & 70 & 24 & $1: 10$ & 154.46 & 11.74 & $<1$ & $<1$ \\
\hline$\%$ RSD & & & & 6 & 6 & $<1$ & $<1$ \\
\hline
\end{tabular}

*Diluted sample concentrations. 
APPENDIX D: ADVANCED ENVIRONMENTAL LABORATORIES' HAA REPORT 


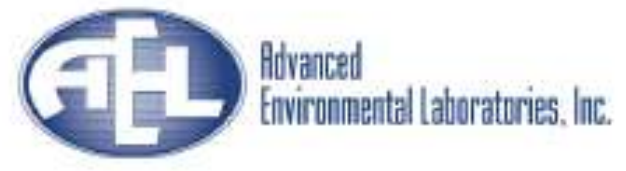
Adranced Environmenta: Laboratories, ine 528 3. North Lake Biva, suse 1016 Azamonte Opringe, EL 3270 Phone: $(407) 937-1594$ Fax: $(407) 937-1597$

ANALYTICAL RESULTS

Workorder: A1400628 DISHWASHER H2O REUSE

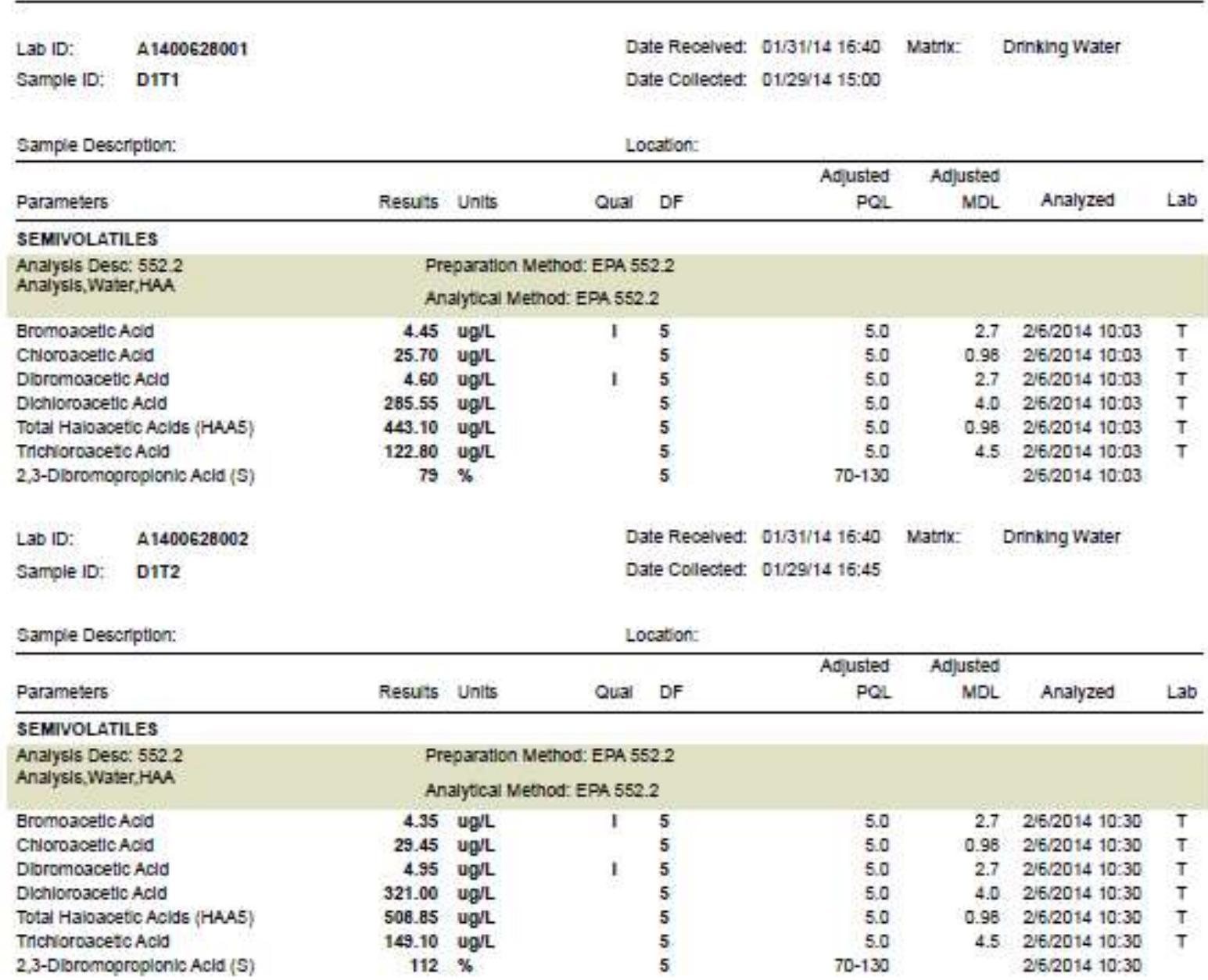


(a) Anvironmental laboratories, Inc.

Advanced Environments Laboratories, Inc $52 B$ 8. North Lake Bwd, Sule 1016 Acamonte Springs, FL 32701

Phone: (407) $937-1554$ Fax (407) $937-1597$

ANALYTICAL RESULTS

Wonkorder: A1400628 DISHWASHER H2O REUSE

\begin{tabular}{|c|c|c|c|c|c|c|c|c|c|}
\hline Lab ID: & A1400628003 & & & \multicolumn{2}{|c|}{ Date Recelved: } & $01 / 31 / 1416: 40$ & Matrtx: & Drinking Water & \\
\hline Sample ID: & D1T3 & & & \multicolumn{2}{|c|}{ Date Collected: } & $01 / 29: 1418: 45$ & & & \\
\hline \multicolumn{2}{|c|}{ Sample Description: } & & & \multicolumn{2}{|c|}{ Location: } & & & & \\
\hline Parameters & & Resuts & Units & Qual & DF & $\begin{array}{l}\text { Adusted } \\
\text { POL }\end{array}$ & $\begin{array}{l}\text { Adjusted } \\
\text { MDL }\end{array}$ & Analyzed & Lab \\
\hline \multicolumn{10}{|c|}{ SEMIVOLATILES } \\
\hline \multirow{2}{*}{\multicolumn{2}{|c|}{$\begin{array}{l}\text { Analysls Desc: } 552.2 \\
\text { Analysis, Water, HAA. }\end{array}$}} & \multicolumn{4}{|c|}{ Preparation Method: EPA 552.2} & & & & \\
\hline & & \multicolumn{4}{|c|}{ Analytica! Method: EPA 552.2} & & & & \\
\hline \multicolumn{2}{|c|}{ Bromoacetic Acid } & 4.65 & ug/L & 1 & 5 & 5.0 & 2.7 & $2 / 6 / 201410: 58$ & $T$ \\
\hline \multicolumn{2}{|c|}{ Chioroacetic Acld } & 34.15 & ug/L & & 5 & 5.0 & 0.98 & $2 / 6 / 2014 \cdot 10.58$ & $T$ \\
\hline \multicolumn{2}{|c|}{ Dloromoacetic Acld } & 5.30 & $\mathrm{ug} / \mathrm{L}$ & & 5 & 5.0 & 2.7 & $2 / 6 / 2014 \quad 10: 58$ & $T$ \\
\hline \multicolumn{2}{|c|}{ Dichloroacetic Acld } & 361.35 & ug/L & & $\mathbf{5}$ & 5.0 & 4.0 & $2 / 6 / 201410: 58$ & $\mathrm{~T}$ \\
\hline \multicolumn{2}{|c|}{ Total Haloacetic Aclds (HAA5) } & 570.30 & ug/L & & 5 & 5.0 & 0.98 & $2 / 6 / 201410: 58$ & $\mathbf{T}$ \\
\hline \multicolumn{2}{|c|}{ Trichioroacetc Acld } & 164.85 & ug/L & & 5 & 5.0 & 4.5 & $2 / 6 / 201410: 58$ & $T$ \\
\hline \multicolumn{2}{|c|}{ 2,3-Dioromopropionic Acld (S) } & 88 & $\%$ & & 5 & $70-130$ & & $2 / 6 / 201410: 58$ & \\
\hline Lab ID: & A1400628004 & & & \multicolumn{2}{|c|}{ Date Recelved: } & $01 / 31 / 1416: 40$ & Matrtx: & Drinking Water & \\
\hline Sample ID: & D1T4 & & & \multicolumn{2}{|c|}{ Date Collected: } & $01 / 30 / 1412: 45$ & & & \\
\hline \multicolumn{2}{|c|}{ Sample Description: } & & & \multicolumn{2}{|c|}{ Location: } & & & & \\
\hline \multirow{2}{*}{\multicolumn{2}{|c|}{ Parameters }} & & & & & Adpusted & Adjusted & & \\
\hline & & Resuts & Units & Qual & DF & POL & MOL & Analyzed & Lab \\
\hline \multicolumn{10}{|c|}{ SEMIVOLATILES } \\
\hline \multirow{2}{*}{\multicolumn{2}{|c|}{$\begin{array}{l}\text { Analysis Desc: } 552.2 \\
\text { Analysis, Water, HAA }\end{array}$}} & \multicolumn{4}{|c|}{ Preparation Method: EPA 552.2} & & & & \\
\hline & & \multicolumn{4}{|c|}{ Analytcal Method: EPA 552.2} & & & & \\
\hline \multicolumn{2}{|c|}{ Bromoacetic Acid } & 5.4 & ug/L & u & 10 & 10 & 5.4 & $2 / 6 / 201411: 25$ & $T$ \\
\hline \multicolumn{2}{|c|}{ Chioroacetic Acld } & 53.40 & ug/L & & 10 & 10 & 2.0 & $2 / 6 / 201411: 25$ & $T$ \\
\hline \multicolumn{2}{|c|}{ Dibromoacetic Acld } & 6.50 & ug/L & 1 & 10 & 10 & 5.4 & $2 / 6 / 201411: 25$ & $T$ \\
\hline \multicolumn{2}{|c|}{ Dichloroacetic Acld } & 621.30 & ughl & & 10 & 10 & 8.1 & $26 / 201411: 25$ & $\mathrm{~T}$ \\
\hline \multicolumn{2}{|c|}{ Total Haloacetic Aclds (HAA5) } & 965.70 & ug/L & & 10 & 10 & 2.0 & $2 / 6 / 201411: 25$ & $\mathrm{~T}$ \\
\hline \multicolumn{2}{|c|}{ Trichioroacetc Acld } & 284.50 & ug/L & & 10 & 10 & 9.1 & $2 / 6 / 201411: 25$ & $T$ \\
\hline 2,3-Dlbromo & roplonic Acld (S) & 110 & $\%$ & & 10 & $70-130$ & & $26 / 201411: 25$ & \\
\hline
\end{tabular}




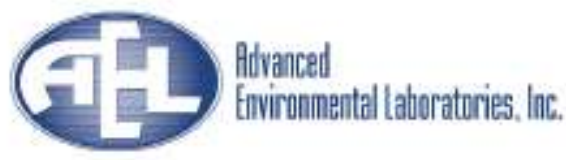

Advanced Envronmenta: Laboratories, ins 528 3. North Lake Glvd, Oute 1016 Navonte Springs, FL 32701

Phone: (407)937-1594 Fax $(407) 937-1597$

ANALYTICAL RESULTS

Workorder: A1400628 DISHWASHER H2O REUSE

\begin{tabular}{|c|c|c|c|c|c|c|c|c|c|}
\hline Lab ID: & A1400628005 & & & \multirow{2}{*}{\multicolumn{2}{|c|}{$\begin{array}{l}\text { Date Recelved: } \\
\text { Date Collected: }\end{array}$}} & $01 / 31 / 1416: 40$ & Matrix: & \multicolumn{2}{|l|}{ Drinking Water } \\
\hline Sample ID: & D1T5 & & & & & $01 / 31 / 1413: 00$ & & & \\
\hline \multicolumn{4}{|c|}{ Sample Description: } & \multicolumn{2}{|c|}{ Location: } & & & & \\
\hline Parameters & & Results & Units & Qual & DF & $\begin{array}{r}\text { Adjusted } \\
P Q \text {. }\end{array}$ & $\begin{array}{r}\text { Adjusted } \\
\text { MDL }\end{array}$ & Analyzed & Lab \\
\hline \multicolumn{10}{|c|}{ SEMIVOLATILES } \\
\hline \multirow{2}{*}{\multicolumn{2}{|c|}{$\begin{array}{l}\text { Analysis Desc: } 552.2 \\
\text { Analysis, Water, HAA }\end{array}$}} & \multicolumn{4}{|c|}{ Preparation Method: EPA 552.2} & & & & \\
\hline & & \multicolumn{4}{|c|}{ Analytcal Method: EPA 552.2} & & & & \\
\hline Bromoacatic, & Acid & 5.4 & ugll & $u$ & 10 & 10 & 5.4 & $2 / 6 / 201411: 53$ & $T$ \\
\hline Chioroacetic, & ald & 72.80 & ugll & & 10 & 10 & 2.0 & $2 / 6 / 201411: 53$ & $T$ \\
\hline Dibromoacet & Acla & 5.4 & ugll & $u$ & 10 & 10 & 5.4 & $2 / 6 / 201411: 53$ & $T$ \\
\hline Dichioroaceth & Acld & 710.90 & uglt & & 10 & 10 & 8.1 & $2 / 6 / 201411: 53$ & $T$ \\
\hline Total Haloace & te Aclds (HAA5) & 1072.50 & ugl & & 10 & 10 & 2.0 & $2 / 6 / 201411: 53$ & $\mathbf{T}$ \\
\hline Trichioroace: & CAcid & 288.80 & ugl & & 10 & 10 & 9.1 & $26 / 201411: 53$ & $T$ \\
\hline 2,3-Dloromop & ropionic Acid (S) & 99 & $\%$ & & 10 & $70-130$ & & $2 / 6 / 201411: 53$ & \\
\hline Lab ID: & A1400628006 & & & & te Recelved: & $01 / 31 / 1416: 40$ & Matrix: & Drinking Water & \\
\hline Sample ID: & D1TS & & & & te Collected: & $01 / 30 / 1415: 35$ & & & \\
\hline \multirow{2}{*}{\multicolumn{2}{|c|}{ Sample Description: }} & & & \multicolumn{2}{|c|}{ Location: } & & & & \\
\hline & & & & & & Adjusted & Adjusted & & \\
\hline Parameters & & Results & Units & Qua: & DF & $P Q L$ & MDL & Analyzed & Lab \\
\hline \multicolumn{10}{|c|}{ SEMIVOLATILES } \\
\hline \multirow{2}{*}{\multicolumn{2}{|c|}{$\begin{array}{l}\text { Analysis Desc: } 552.2 \\
\text { Analysis, Waver, HAA }\end{array}$}} & \multicolumn{4}{|c|}{ Preparation Method: EPA 552.2} & & & & \\
\hline & & \multicolumn{4}{|c|}{ Analytcal Method: EPA 552.2} & & & & \\
\hline \multicolumn{2}{|c|}{ Bromoacetic Acid } & 5.4 & ugl & $u$ & 10 & 10 & 5.4 & $2 / 6 / 2014 \quad 12: 20$ & $T$ \\
\hline \multicolumn{2}{|c|}{ Chioroacetic Acid } & 70.20 & ugll & & 10 & 10 & 2.0 & $26 / 2014 \quad 12: 20$ & $T$ \\
\hline \multicolumn{2}{|c|}{ Dibromoacetic Acld } & 5.4 & ugl & $u$ & 10 & 10 & 5.4 & $2 / 6 / 201412: 20$ & $T$ \\
\hline \multicolumn{2}{|c|}{ Dichioroacetic Acld } & 644.10 & ug/L & & 10 & 10 & 8.1 & $2 / 6 / 2014 \quad 12: 20$ & $T$ \\
\hline \multicolumn{2}{|c|}{ Total Haloacetic Aclds (HAA5) } & 1063.70 & ugll & & 10 & 10 & 2.0 & $2 / 6 / 201412: 20$ & $\mathbf{T}$ \\
\hline \multicolumn{2}{|c|}{ Trichioroacetic Acld } & 349.40 & ugh & & 10 & 10 & 9.1 & $2 / 6 / 201412: 20$ & $T$ \\
\hline \multicolumn{2}{|c|}{ 2,3-Dioromoproplonic Acld (S) } & 105 & $\%$ & & 10 & $70-130$ & & $2 / 6 / 2014 \quad 12: 20$ & \\
\hline
\end{tabular}


Adranced Environmenta: Laboratories, inc 528 3. North Lake Blvd, Sutse 1016 Azamonte Oprings, FL 32701 Fhone: (407)937-1594 Fax: (407) $937-1597$

\section{ANALYTICAL RESULTS}

Workorder; A1400628 DISHWASHER H2O REUSE

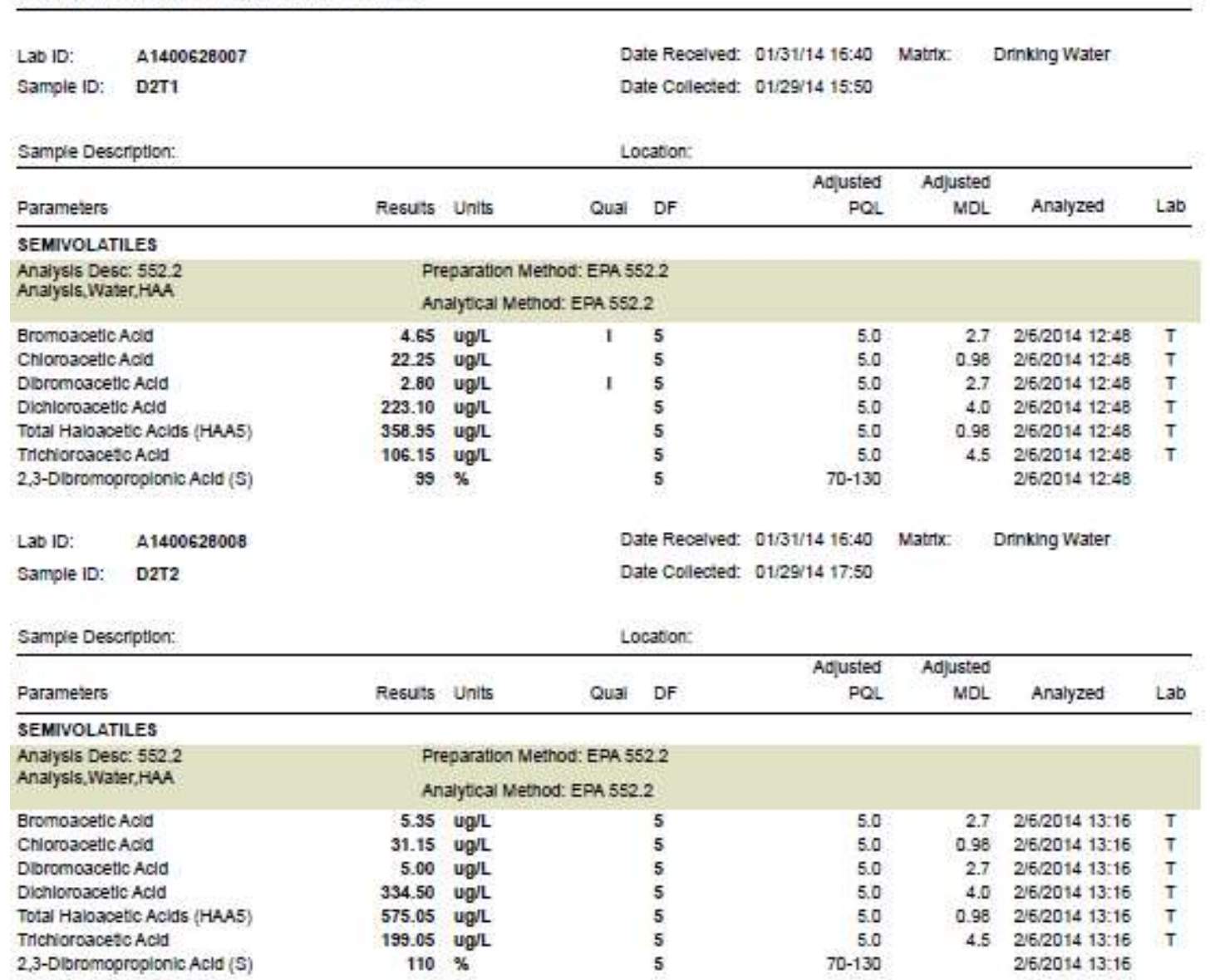




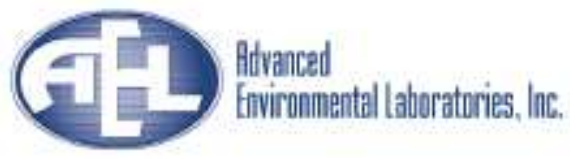

ANALYTICAL RESULTS

\begin{tabular}{|c|c|c|c|c|c|c|c|c|c|}
\hline Lab ID: & A 1400628009 & & & \multirow{2}{*}{\multicolumn{2}{|c|}{$\begin{array}{l}\text { Date Recelved: } \\
\text { Date Collected: }\end{array}$}} & $01 / 31 / 1416: 40$ & Matrix: & \multicolumn{2}{|l|}{ Drinking Water } \\
\hline Sample ID: & $\mathrm{D} 2 \mathrm{~T} 3$ & & & & & $01 / 29 / 1419: 35$ & & & \\
\hline \multicolumn{4}{|c|}{ Sample Description: } & \multicolumn{3}{|c|}{ Location: } & & & \\
\hline Parameters & & Resuts & Units & Qu3! & DF & $\begin{array}{l}\text { Adjusted } \\
\text { POL }\end{array}$ & $\begin{array}{l}\text { Ad)usted } \\
\text { MDL }\end{array}$ & Analyzed & Lab \\
\hline \multicolumn{10}{|c|}{ SEMIVOLATILES } \\
\hline \multirow{2}{*}{\multicolumn{2}{|c|}{$\begin{array}{l}\text { Analysis Desc: } 552.2 \\
\text { Analysis, Water, HAA }\end{array}$}} & \multicolumn{4}{|c|}{ Preparation Method: EPA 552.2} & & & & \\
\hline & & \multicolumn{4}{|c|}{ Analytcal Method: EPA 552.2} & & & & \\
\hline \multicolumn{2}{|c|}{ Bromoacetic Acid } & 5.20 & ugll & & 5 & 5.0 & 2.7 & $2 / 6: 201414: 12$ & $\mathrm{~T}$ \\
\hline \multicolumn{2}{|c|}{ Chioroacetic Acld } & 36.30 & ug/L & & 5 & 5.0 & 0.98 & $2 / 6 / 201414: 12$ & $T$ \\
\hline \multicolumn{2}{|c|}{ Dibromoacetic Acld } & 4.75 & ug/L & 1 & 5 & 5.0 & 2.7 & $2 / 6 \sqrt{2014} 14: 12$ & $T$ \\
\hline \multicolumn{2}{|c|}{ Dichloroacetic Acid } & 364.90 & ugh & & 5 & 5.0 & 4.0 & $2 / 6 / 201414: 12$ & $T$ \\
\hline \multicolumn{2}{|c|}{ Total Haloacetic Aclds (HA.A5) } & 621.85 & ug/L & & 5 & 5.0 & 0.98 & $2 / 6 / 2014: 14: 12$ & $T$ \\
\hline \multicolumn{2}{|c|}{ Trichioroacetc Acld } & 210.70 & ugll & & 5 & 5.0 & 4.5 & $2: 6 / 2014,14: 12$ & $T$ \\
\hline \multicolumn{2}{|c|}{ 2,3-Dioromopropionic Acid (S) } & 120 & $\%$ & & 5 & $70-130$ & & $2 / 6 / 201414: 12$ & \\
\hline \multirow{2}{*}{$\begin{array}{l}\text { Lab ID: } \\
\text { Sample ID: }\end{array}$} & A 1400628010 & & & \multirow{2}{*}{\multicolumn{2}{|c|}{$\begin{array}{l}\text { Date Recelved: } \\
\text { Date Collected: }\end{array}$}} & $01 / 31 / 1416: 40$ & Matrix: & \multirow[t]{2}{*}{ Drinking Water } & \\
\hline & D2T4 & & & & & $01 / 30 / 1413: 45$ & & & \\
\hline \multicolumn{2}{|c|}{ Sample Description: } & & & \multicolumn{2}{|c|}{ Location: } & & & & \\
\hline \multirow{2}{*}{\multicolumn{2}{|c|}{ Parameters }} & & & & & Actusted & Adjusted & & \\
\hline & & Resuts & Units & Qual & DF & POL & MOL & Analyzed & Lab \\
\hline \multicolumn{10}{|c|}{ SEMIVOLATILES } \\
\hline \multirow{2}{*}{\multicolumn{2}{|c|}{$\begin{array}{l}\text { Analysls Desc: } 552.2 \\
\text { Analysls, Water,HAA }\end{array}$}} & \multicolumn{4}{|c|}{ Preparation Method: EPA 552.2} & & & & \\
\hline & & \multicolumn{4}{|c|}{ Analytical Method: EPA 552.2} & & & & \\
\hline \multicolumn{2}{|c|}{ Bromoacetic Acid } & 5.4 & ugll & u & 10 & 10 & 5.4 & $2 / 6: 201414: 40$ & $T$ \\
\hline \multicolumn{2}{|c|}{ Chioroacetic Acld } & 62.40 & ugll & & 10 & 10 & 2.0 & $2 / 6 / 2014: 14: 40$ & $T$ \\
\hline \multicolumn{2}{|c|}{ Dibromoacetic Acid } & 5.4 & ugll & $u$ & 10 & 10 & 5.4 & $2 / 6 / 201414: 40$ & $T$ \\
\hline \multicolumn{2}{|c|}{ Dichloroacetic Acid } & 647.10 & ugll & & 10 & 10 & 8.1 & $2 / 6 / 201414: 40$ & $T$ \\
\hline Total Haloac & tc Aclds (HAA5) & 1026.80 & ugll & & 10 & 10 & 2.0 & $2 / 6 / 201414: 40$ & $T$ \\
\hline Trichioroace & cAcid & 317.30 & ugll & & 10 & 10 & 9.1 & $26 / 201414: 40$ & $T$ \\
\hline 2,3-Dibromo & ropionic Acid (S) & 100 & $\%$ & & 10 & $70-130$ & & $2 / 6 / 201414: 40$ & \\
\hline
\end{tabular}




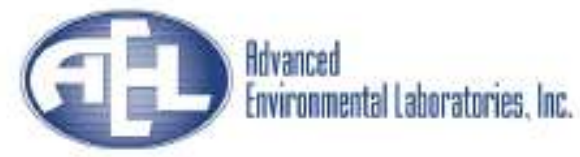

Advanced Environmenta Laboratories, ine

528 a. North Lake Bivd, Sutse 1016

Neamonte Springs, FL 32701

Phone: (407)937-1594

Fax (407) $937-1597$

ANALYTICAL RESULTS

Workcrder: A1400628 DISHWASHER H2O REUSE

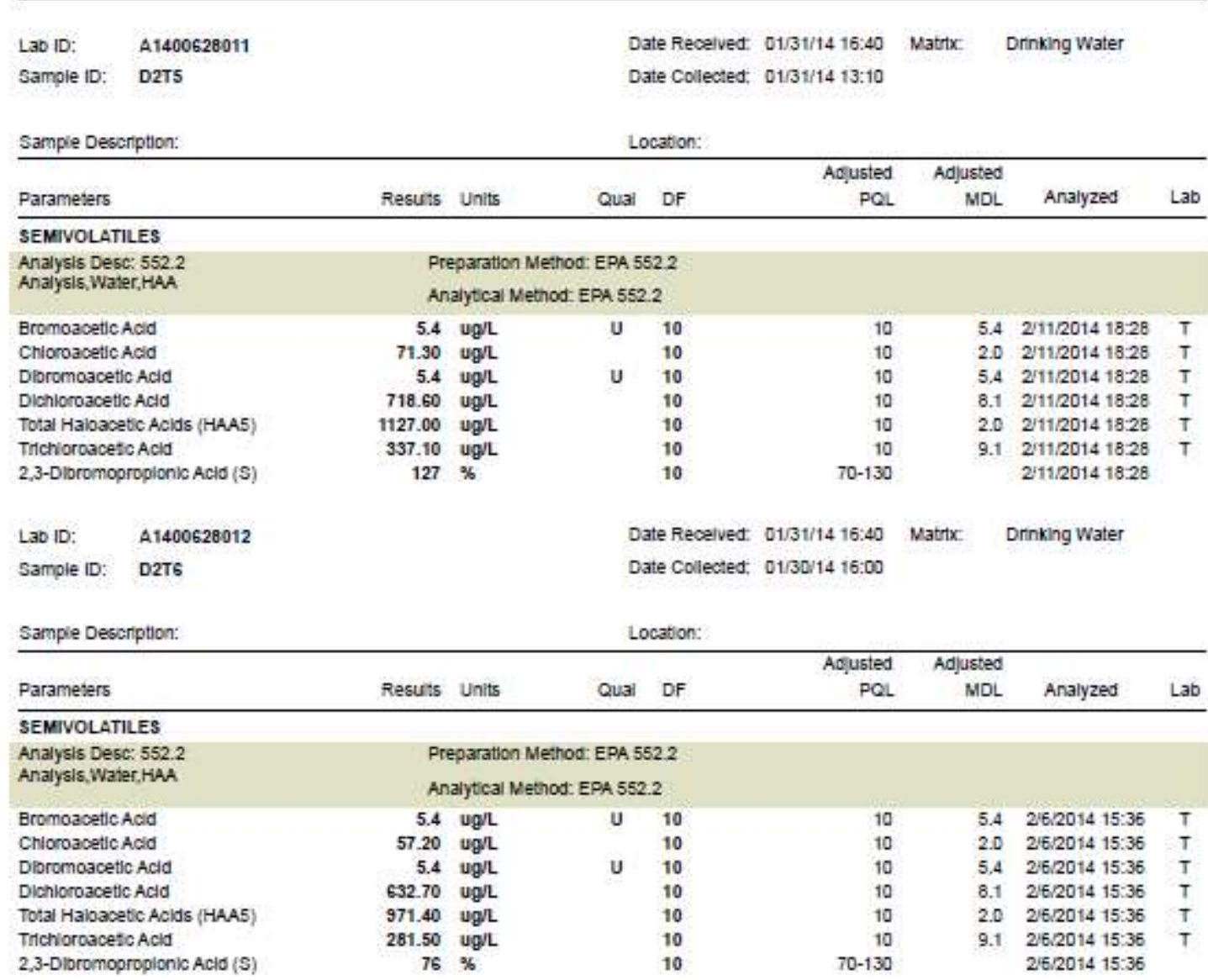


APPENDIX E: DBP VOLATILIZATION MODEL 


\section{Disinfection by-product (DBP) vaporization}

To evaluate potential health concerns associated with volatile DBP, dynamic modeling software was used to predict concentrations of free chlorine residuals, DBP production and DBP vaporization.

\section{Chlorine consumption}

Chlorine consumption was modeled based on data from an experiment that measured chlorine residuals over time in UF/EC treated dishwater. The treated dishwashing water $(\mathrm{pH}$ 9.6 \pm 0.1, TOC $=95 \mathrm{mg} / \mathrm{L})$ was dosed with chlorine and incubated at $32^{\circ} \mathrm{C}$ for different times $(2,4$, 6, 24, and $48 \mathrm{hrs})$ at different sodium hypochlorite $(\mathrm{NaOCl})$ doses $(60,70$, and $75 \mathrm{mg} \mathrm{Cl} / \mathrm{L})$. Frequently, chlorine decay in the bulk phase is characterized by a first-order kinetic model as follows:

$$
\mathrm{dc} / \mathrm{dt}=-\mathrm{kc}
$$

where $\mathrm{c}=$ chlorine concentration; $\mathrm{k}=$ first-order decay constant and $\mathrm{t}=$ time (Biswas et al. 1993).

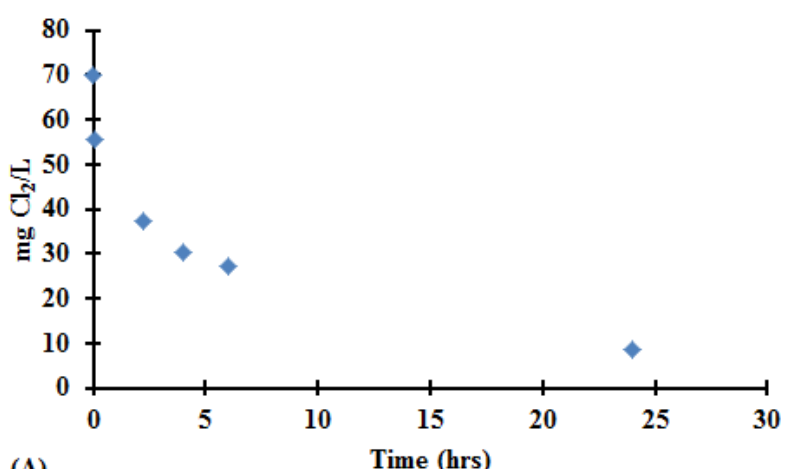

(A)

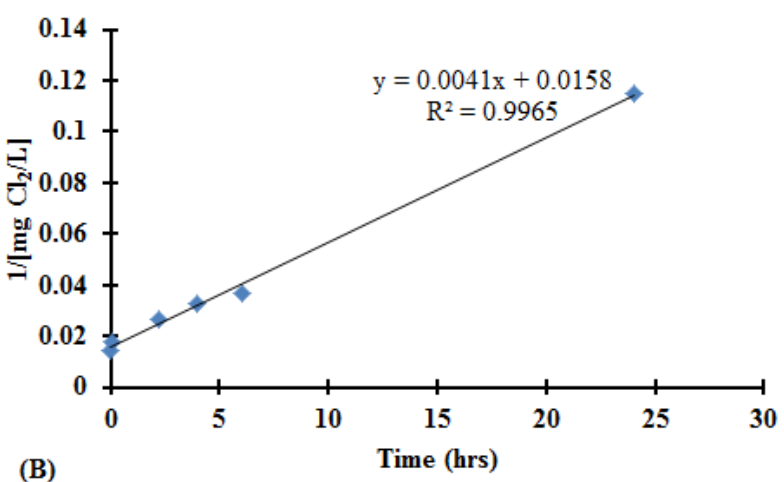

(B)

Figure E1. A) Shows the decay of chlorine consumption $(70 \mathrm{mg} / \mathrm{L})$ in treated greywater over 24 hours. B) Plots the inverse concentrations against time to get a $\mathrm{k}=.0041 \mathrm{mg} / \mathrm{L}^{-1} \mathrm{hr}^{-1}$

The results from the UF/EC greywater experiment, however; shows a second order decomposition reaction. This is likely explained by the chlorine reacting with organic material rather than with the surface of pipes, therefore, 


$$
\mathrm{HOCl}+\mathrm{TOC} \rightarrow \text { products }
$$

A paper looking at chlorine demand and TTHM formation kinetics supports this concept (Clark 1998). The kinetic model developed in study is summarized below.

$$
r_{C l_{2}}=-k\left(C l_{2}\right)(\mathrm{TOC})
$$

Where $r_{\mathrm{Cl}_{2}}=$ chlorine decay in $\mathrm{mg} / \mathrm{L}$ per hour, $\mathrm{k}=$ rate constant $\left(\mathrm{mg} / \mathrm{L}^{-1} \mathrm{hr}^{-1}\right),\left(C l_{2}\right)=$ chlorine concentration $\left(\mathrm{Cl}_{2} \mathrm{mg} / \mathrm{L}\right)$, and $\mathrm{TOC}=$ total organic carbon. Since the organic contaminants are so much more abundant in the water than the chlorine, their concentration is nearly constant and can be lumped into an effective first order rate constant ( $\left.\mathrm{k}_{\text {eff }}\right)$.

$$
r_{C l_{2}}=-k_{e f f}\left(C l_{2}\right)
$$

$\mathrm{K}_{\text {eff }}$ was found assuming the TOC in the experiment was much greater than $\mathrm{Cl}_{2}$ concentrations $\left(\mathrm{K}_{\mathrm{eff}}=0.0041\right)$ and effective first order reaction was integrated to model chlorine concentration with time.

$$
C l_{2}(t)=C l_{2}(t, 0) e^{-k_{e f f} \times t}
$$

\section{Chloroform Production}

Disinfection by-production formation has been extensively studied since the early 1970's. Among all the chlorinated by-products, chloroform certainly attracts a large amount of attention. Many studies have shown the influence of parameters like dose of chlorine, $\mathrm{pH}$, temperature, content of organic matter and concentration of bromide or ammonia on chloroform production kinetics (Gallard and von Gunten 2002, Liang and Singer 2003, Trussell and Umphres 1978). This means predicting or modeling chloroform production is specific to the water being disinfected. Unfortunately, in the case of the treated dishwater, no literature contains kinetic information in very high organic, $\mathrm{pH}$, and temperature environments $(\mathrm{TOC}=95 \mathrm{mg} / \mathrm{L}, 9.5$ and 
$55^{\circ} \mathrm{C}$ ). Therefore a combination of literature and experimental data was used to model chloroform production. Experimental data was developed by treated dishwashing water $\mathrm{pH}$ 9.6 $\pm 0.1, \mathrm{TOC}=95 \mathrm{mg} / \mathrm{L})$ dosed with chlorine $(70 \mathrm{mg} / \mathrm{L})$ and incubated at $32^{\circ} \mathrm{C}$ for different times $(2,4,6,24$, and $48 \mathrm{hrs})$ and analyzing DBP production.

A study published in 2002 evaluated the kinetics of chlorination and THM formation (Gallard and von Gunten 2002). They found that THM precursors can be described as initial THM formation potential (THMFPi) that corresponds to fast reacting THM precursors (with 3 hours) and THMFP that responds to slowly reacting THM precursors ( 3 weeks). The kinetic model used for this volatile chloroform production model is based on the kinetics described in this paper. Several studies, including Gallard and Guntens (2002) paper, show second order kinetics, first order in chlorine and first order in reacting substances (THMFP). Therefor the rate of THM formation is given as:

$$
\frac{d[T H M]}{d t}=k \times\left[\mathrm{Cl}_{2}\right] \times[T H M F P]
$$

Where [THMFP] is the concentration of the slowly reacting THM (THM after 48 hours in this case), $\left[\mathrm{Cl}_{2}\right]$ is the concentration of chlorine at time $\mathrm{t}$, and $\mathrm{k}$ is the second order rate constant. Integrating the above equations yields,

$$
\frac{1}{\left(\left[C l_{2}\right]_{i}-[T H M F P]\right)} \times \ln \left(\frac{\left(\left[C l_{2}\right] \times[T H M F P]\right)}{\left[C l_{2}\right]_{i}([T H M F P]-[T H M]}\right)=k t
$$

Where $\left[\mathrm{Cl}_{2}\right]_{i}$ is the concentration of chlorine after the initial chlorine consumption ( $\mathrm{t}=2.25$ and $[\mathrm{THM}]=[0.43 \mathrm{ppm}])$ and $[\mathrm{THMFP}]$ is the total concentration of slowly reacting THM precursors. Unfortunately, the experimental DBP production data over time is with HAAs, however, there are 24 and 48 hour data for THMs. Figure 3a shows that the experimental data for HAAs follows the kinetics of Gallards and Guntens (2002) study. This kinetic model was then 
applied to the 24 and 48 hour data for chloroform (Figure E2b) to obtain a k value $\left(0.0079 \mathrm{mg} \mathrm{L}^{-}\right.$ ${ }^{1} \mathrm{hr}^{-1}$ ) for modeling chloroform production.

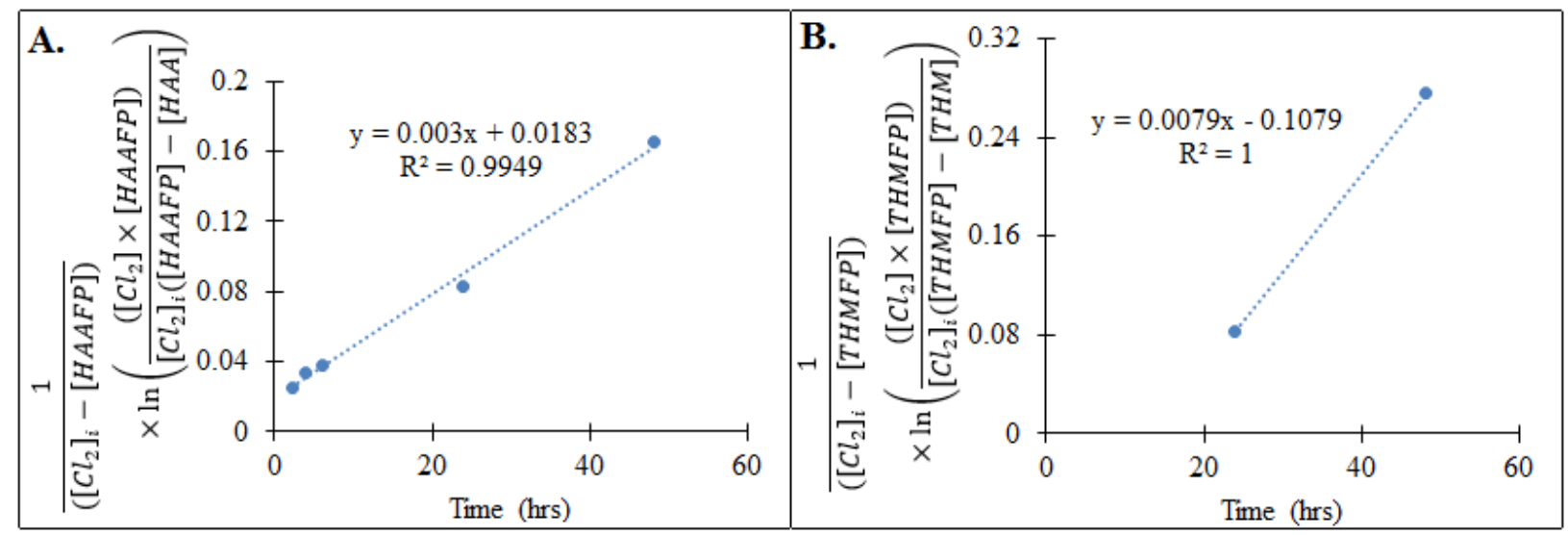

Figure E2. A) experimental data for HAA production. B) experimental data for THM production

\section{Chloroform Vaporization}

The kinetics for chloroform vaporization had to be fully assumed based on literature data because no experimental data was taken. Based on literature, many parameters can influence chloroform vaporization, including flow rate, temperature, ventilation, and $\mathrm{pH}$. A chloroform vaporization model was developed from two publications. The first is a study by Howard and Corsi (1996) that looked at chloroform vaporization from kitchen sinks and the second is a paper by the same authors that look at chloroform vaporization from dishwashers.

Simplifying mass transfer to only volatilization can be expressed as:

$$
\frac{d C V}{d t}=-K_{L}\left(C-\frac{C_{g}}{H_{C}}\right) A
$$

Where $\mathrm{C}=$ chloroform concentration in water $\mathrm{mg}, \mathrm{V}=$ local volume of water in $\mathrm{m}^{3} \mathrm{t}=$ time in hours, $\mathrm{K}_{1}$ mass transfer coefficient, $\mathrm{C}_{\mathrm{g}}=$ contaminant in air adjacent to water $\mathrm{mg} / \mathrm{m}^{3}, \mathrm{H}_{\mathrm{c}}=$ Henry's law coefficient and A= interfacial surface area between water and air. 
The paper modeling kitchen sink vaporization kinetics continues to develop the following equation.

$$
C_{g}=C_{l}\left(\frac{Q_{l}}{Q_{v}}\right) f\left\{1-e^{\frac{-t}{\Phi_{a}}}\right\}
$$

Where $C_{g}$ is the contaminant concentration in room air $\left(\mathrm{mg} / \mathrm{m}^{3}\right), C_{l}$ is the contaminant concentration in water $\left(\mathrm{mg} / \mathrm{m}^{3}\right), Q_{l}=$ water flow rate in $\mathrm{m}^{3} / \mathrm{hr}, Q_{l}=$ room ventilation rater in $\mathrm{m}^{3} / \mathrm{hr}$, $\mathrm{f}$ is contaminant stripping efficiency, $\mathrm{t}=$ time in hours, $\emptyset_{a}$ is average residence time for air in room (hrs) and $\mathrm{V}$ is room volume in $\mathrm{m}^{3}$.

The stripping efficiency was taken from the paper discussing chemical vaporization in dishwashers. The stripping efficiency of $97 \%$ was selected because of the high temperature $\left(55^{\circ} \mathrm{C}\right)$ and presence of dishes used during the experiment. The stripping efficiency is given for toluene, but the author states the factor could be used for chloroform as well at high temperatures.

\section{$\underline{\text { Stella model }}$}

Assumptions

Dynamic programing software (STELLA, isee systems, Lebanon, NH, USA) was used to predict the accumulation of volatile chloroform within the tent of the dishwashing unit. The dynamic model used $\mathrm{k}$ values and equations from experimental data and literature. All assumptions are listed below.

- Organics in holding tank: $92.5 \mathrm{mg} \mathrm{L}^{-1} \mathrm{TOC}$

- Chlorine in holding tank: $70 \mathrm{mg} \mathrm{Cl}_{2} \mathrm{~L}^{-1}$ dose once every 24 hours

- Chlorine consumption in holding tank: $0.0041 \mathrm{mg} \mathrm{Cl}_{2} \mathrm{~L}^{-1} \mathrm{hr}^{-1} \times \mathrm{Cl}_{2}$ in holding tank (mg $\left.\mathrm{Cl}_{2} \mathrm{~L}^{-1}\right) \times$ TOC in holding tank $\left(\mathrm{mg} \mathrm{L}^{-1}\right)$

- Chloroform production: $0.0079 \mathrm{mg} \mathrm{L}^{-1} \mathrm{hr}^{-1} \times \mathrm{Cl}_{2}$ in holding tank $\left(\mathrm{mg} \mathrm{Cl}_{2} \mathrm{~L}^{-1}\right) \times \mathrm{TOC}$ in holding tank $\left(\mathrm{mg} \mathrm{L}^{-1}\right)$ 
- Chloroform removed to waste: chloroform in holding tank (chloroform production) $\times 1 / 3$ pulsed twice a day (dilution factor)

- Chloroform vaporization: $0.97 \times$ chloroform in holding tank (chloroform production)

- Chloroform vapor loss to ventilation: air exchanges $(0.2) \times$ chloroform vapor $(\mathrm{ppm})$

- Tent volume: $70 \mathrm{~m}^{3}$

- Temperature for chlorine consumption and chloroform production $\mathrm{k}$ values were $32^{\circ} \mathrm{C}$ while temperature for vaporization was $55^{\circ} \mathrm{C}$ (worst case scenario).

- Air temperature: $25^{\circ} \mathrm{C}$

\section{Configuration}

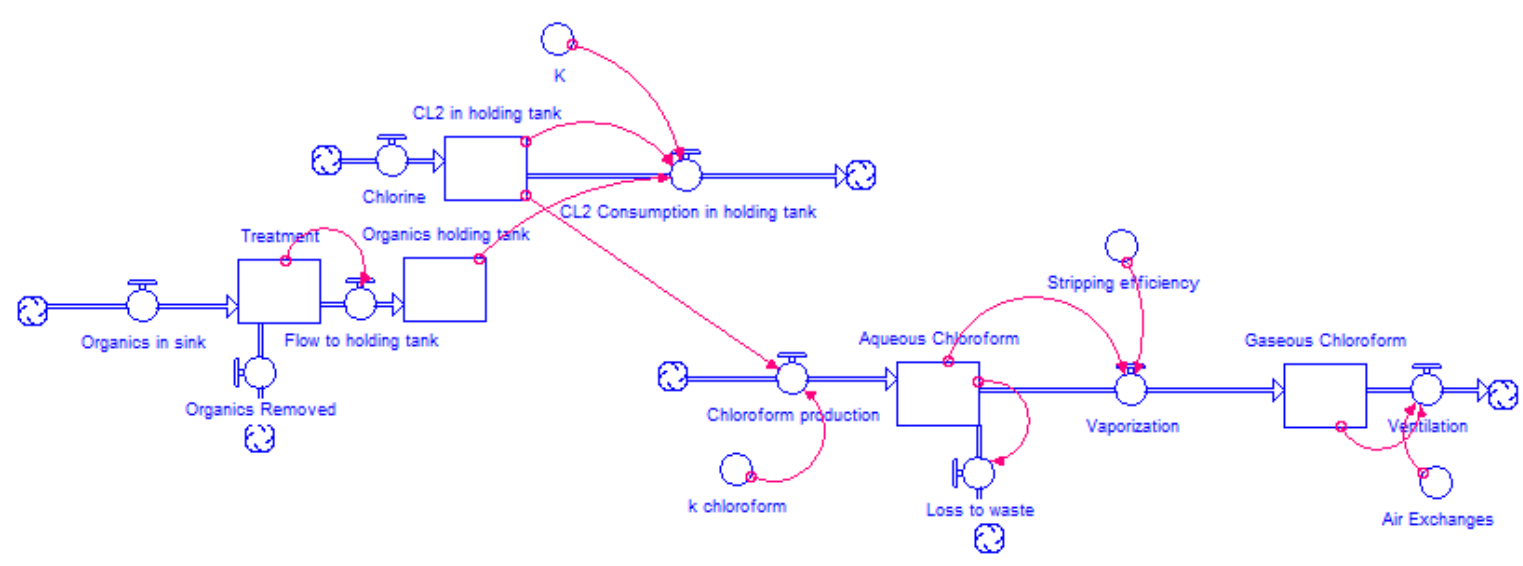

Figure E3. Stella model configuration. 


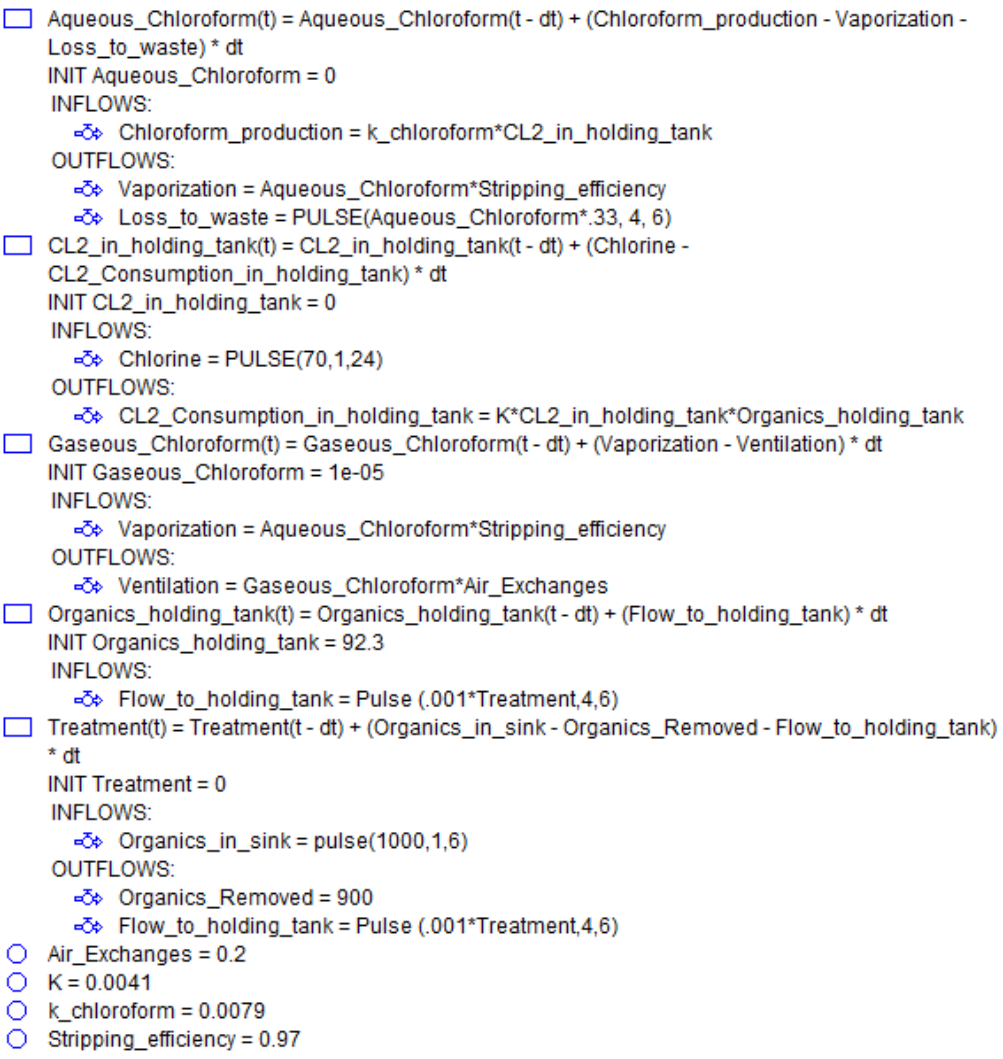

Figure E4. Stella model equations.

\section{Results}

The developed model predicts that if dosed with $70 \mathrm{mg} \mathrm{Cl}_{2} / \mathrm{L}$, the chlorine residual will be reduced to $8.79 \mathrm{mg} \mathrm{Cl} / 2$ after 24 hours. This residual is higher than what is recommended by most greywater reuse standards, but represents a worst case scenario for chloroform production. Figure $\mathrm{E} 5$ shows $\mathrm{Cl}_{2}$ concentrations over 72 hours. 


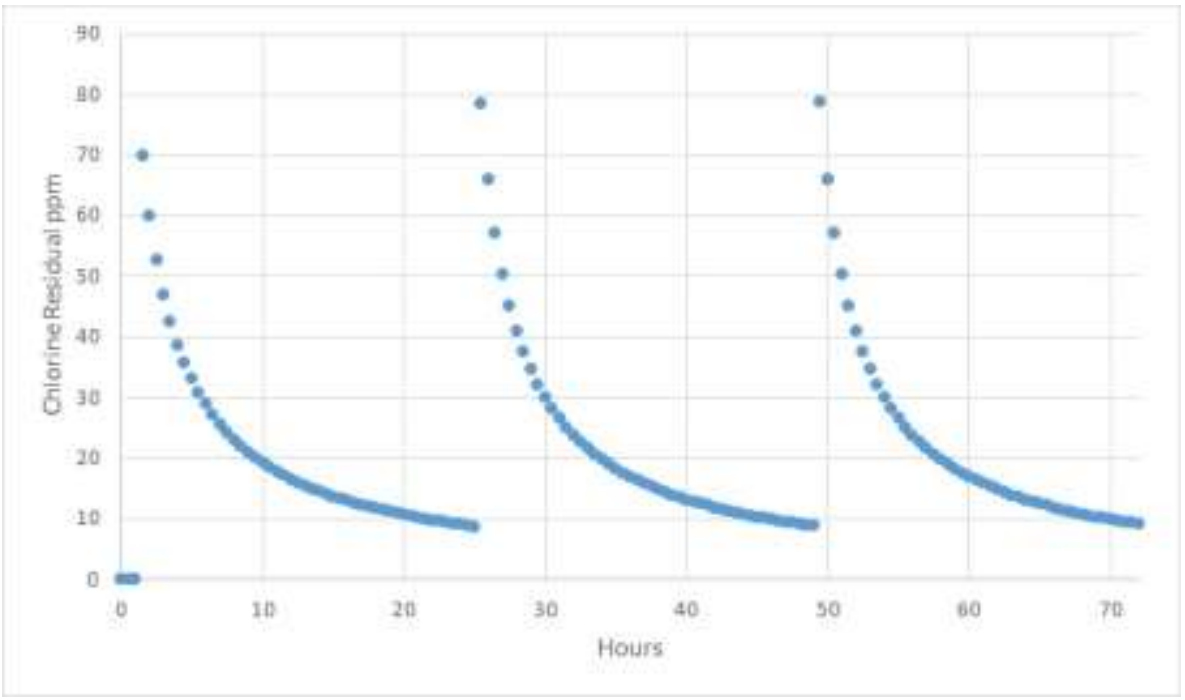

Figure E5. Chlorine Residual (mg $\left.\mathrm{Cl}_{2} / \mathrm{L}\right)$ in the holding tank over 72 hours.

Aqueous chloroform concentrations showed a spike of $0.45 \mathrm{ppm}$ soon after chlorination followed by a series of gradual and sharp decreases, likely due to vaporization and a dilution effect from the sanitizing water, respectively. The aqueous chloroform concentrations fall to $0.072 \mathrm{ppm}$ right before the holding tank is dosed on the following day. Figure E6 shows aqueous chloroform concentrations over 72 hours. 


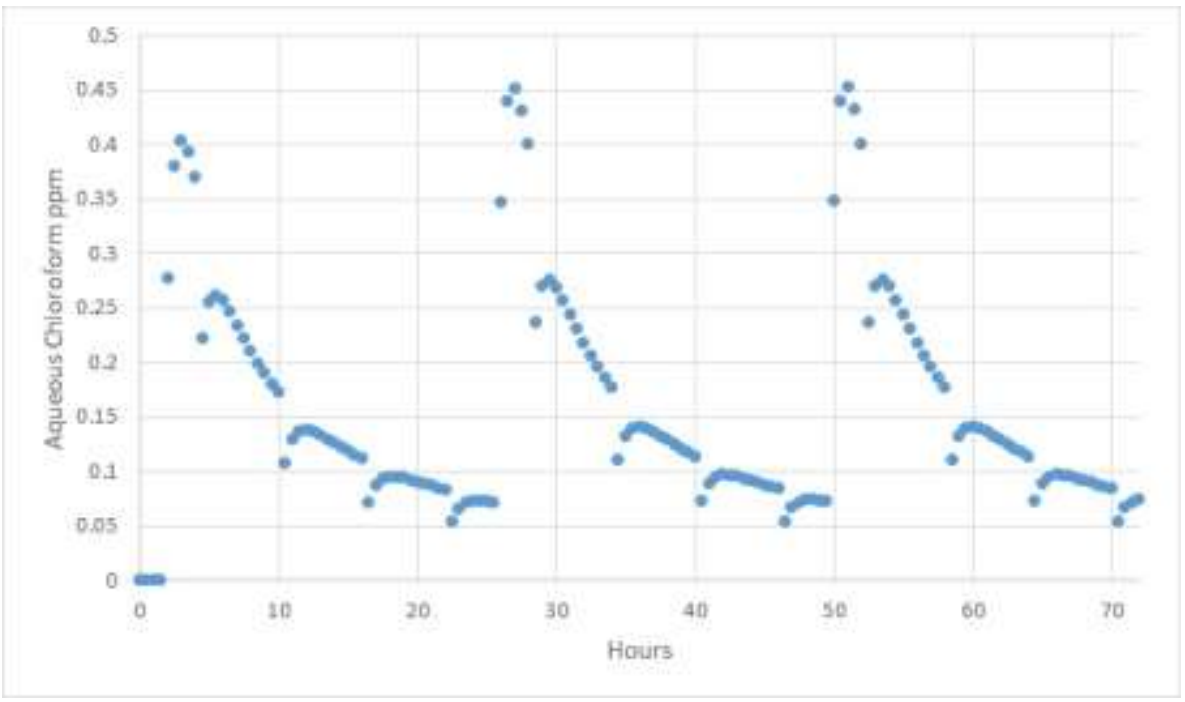

Figure E6. Aqueous Chloroform (mg/L) in the holding tank over 72 hours.

Gaseous chloroform showed a spike at $1.16 \mathrm{ppm}$ soon after chlorination and a decrease to $0.47 \mathrm{ppm}$ over the remainder of the day. Figure E7 shows gaseous chloroform concentrations in a 70 cubic meter tent with an air exchange rate of $0.2 /$ hour. It is important to note that these concentrations will vary greatly depending on tent size, temperature and ventilation rates. The model is meant to display a worst case situation with minimal ventilation and a small tent, therefore the gaseous chloroform is likely to be much lower. In any case, proper ventilation, especially after chlorinating, will ensure the safety of the dishwashing personnel. 


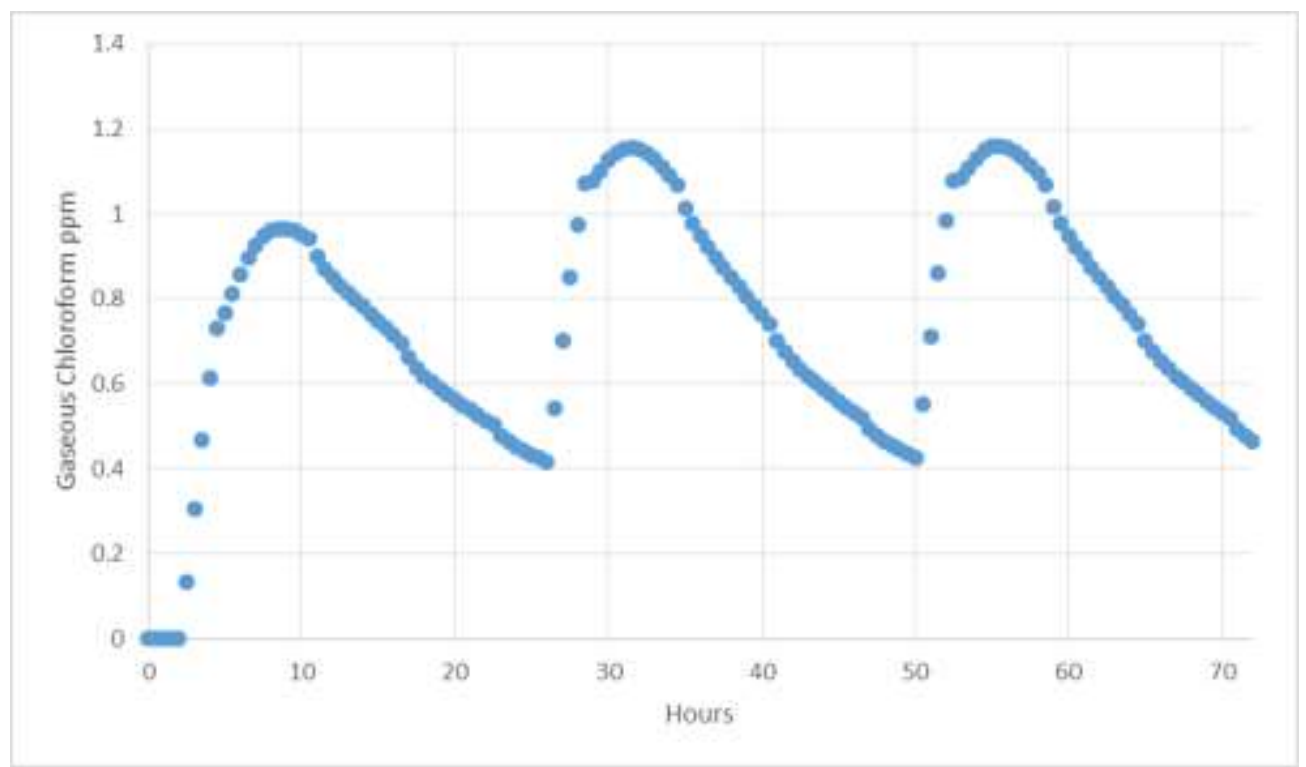

Figure E7. Gaseous Chloroform (ppm) in the military dishwashing tent over 24 hours.

\section{Conclusion}

The dynamic model developed on rate constants derived from experimental data shows a maximum gas chloroform of $1.16 \mathrm{ppm}$. The U.S. Occupational Safety \& Health Administration (OSHA) requires chloroform concentrations to be below $50 \mathrm{ppm}$, but recommend that the permissible exposure limit be reduced to $2 \mathrm{ppm}$ within an hour. Although the model predicts chloroform concentrations will not exceed the OSHA standards, proper ventilation (especially after adding chlorine) will ensure the safety of the dishwashing personnel. The developed model is based off several assumptions, to fully understand the risk of chloroform to health, full scale studies need to be performed. 


\section{APPENDIX F: QMRA REPORT}


Estimation of the ratio of $E$. coli $\mathrm{O} 157: \mathrm{H} 7$ to total $E$. coli in dishwashing water

Ground beef has been implicated in the majority of food-related E. coli O157:H7

outbreaks in the U.S. (FSIS, 2001), therefore the ratio of E. coli O157:H7 to total E. coli in ground beef may be the closest approximation to the ratio in dishwashing water. Eisel et al.

(1997) reported ranges of 10 to $100 \mathrm{cfu} \mathrm{g}^{-1}$ of $E$. coli in ground beef. The E. coli O157:H7 strain is found in $0.2 \%$ to $0.5 \%$ of ground beef samples, in concentrations ranging from 1 to 3 bacteria per gram typical serving size of $87 \mathrm{~g}$ (UFSaIS, 2001). Based on this information, the ratio of $E$. coli $\mathrm{O} 157: \mathrm{H} 7$ to total $E$. coli in ground beef (and the assumed ratio in dishwashing water) can be calculated as follows:

Lower estimate:

- Assumed concentration of E. coli O157:H7: 1 bacteria / $87 \mathrm{~g}$ of ground beef

- Assumed concentration of total E. coli: $100 \mathrm{cfu} / \mathrm{g}$ of ground beef

- Assumed fraction of ground beef servings with E. coli O157:H7: 0.2\%

- Calculation: Ratio $=(1 / 87) / 100 * 0.002=2.3 \times 10^{-7}$

Upper estimate:

- Assumed concentration of E. coli O157:H7: 3 bacteria / $87 \mathrm{~g}$ of ground beef

- Assumed concentration of total E. coli: $10 \mathrm{cfu} / \mathrm{g}$ of ground beef

- Assumed fraction of ground beef servings with E. coli $\mathrm{O} 157: \mathrm{H} 7: 0.5 \%$

- Calculation: Ratio $=(3 / 87) / 10 * 0.005=1.7 \times 10^{-5}$

For the purposes of this study, it is assumed that the ratio of $E$. coli $\mathrm{O} 157: \mathrm{H} 7$ to total $E$. coli in dishwashing water is between $2.3 \times 10^{-7}$ and $1.7 \times 10^{-5}$, and the higher of the two ratios was chosen as a conservative approach. 


\section{Quantitative Microbial Risk Assessment (QMRA) Model}

\section{Dose-Response Curves}

The QMRA model was ran by a collaborator, Matt Verbyla, at the University of South Florida. The following is the model he developed.

The Pfaff transformation of the hypergeometric dose-response model for norovirus (Eq. (F1)) was used with previously-published best-fit values for model parameters $\alpha, \beta$, and $a$, without making any assumptions about virus aggregation (using the best-fit values from the combined inocula (8fIIa $+8 \mathrm{fIIb})$ used by (Teunis et al., 2008). The Pfaff transformation, which is a close approximation to the original model (assuming all doses $\leq 33,323$ ) is necessary here since the best-fit value for parameter $a$ provided by Teunis et al. (2008) exceeds one of the constraints of the Gauss hypergeometric function (Fiona Barker et al., 2013; Mok et al., 2014).

$p_{\text {inf }}=1-\left({ }_{2} F_{1}\left(\beta, \frac{\lambda(1-a)}{a}, \alpha-\beta ; a\right)\left(\frac{1}{1-a}\right)^{-\left(\frac{\lambda(1-a)}{a}\right)}\right)$

The approximate Beta-Poisson dose-response model (Eq. (2)) was used for both Salmonella spp. and pathogenic E. coli O157:H7 (Soller et al., 2010). The use of this approximate model (instead of the exact model) is valid for Salmonella and E. coli O157:H7 since $\beta » 1$ and $\alpha \ll \beta$ (Teunis and Havelaar, 2000).

$p_{\text {inf }}=1-\left(1+\frac{\lambda}{\beta}\right)^{-\alpha}$ 


\section{Maximum tolerable probability of illness}

In order to establish maximum limits for the concentration of pathogenic microorganisms in reclaimed greywater, it is necessary to first establish a maximum tolerable probability of illness resulting from microbial infections. Maximum contaminant levels established by the U.S. EPA for chemicals and radionuclides have been determined based on a tolerable lifetime risk which is two orders of magnitude lower than the overall incidence of cancer in the U.S. (Munro and Travis, 1986; Mara et al., 2010). The U.S. EPA has previously recommended a maximum annual waterborne-disease infection risk of $10^{-4}$ (Macler and Regli, 1992), but this recommendation was based on background waterborne disease prevalence in the U.S. Individuals in military field settings already experience a high incidence of diarrheal disease, with average estimates ranging from 6 to 29 cases per 100 person-months in the field (Riddle et al., 2006). Using Equation F4, where $n=30$ days per month, assuming that the monthly risk of illness per person $\left(P_{\text {ill }}\right)$ is equal to 6 cases per 100 person-months $(6.0 \%)$, the daily incidence of diarrheal disease for individuals in military field settings ( $\left.p_{\text {ill }}\right)$ would be equivalent to approximately $0.2 \%$.

$P_{\text {ill }}=1-\left(1-p_{\text {ill }}\right)^{n}$

A maximum tolerable daily probability of illness $0.002 \%\left(2 \times 10^{-5}\right)$ was chosen for this study, since this risk is two orders of magnitude lower than the current incidence of diarrheal disease for people in military field settings. In other settings, where the existing incidence of disease is lower, this level of risk may be considered to be too high by local stakeholders. Water reuse guidelines should be set with consideration for the local context and the existing health burden affecting the population. 


\section{Code used in ' $R$ '}

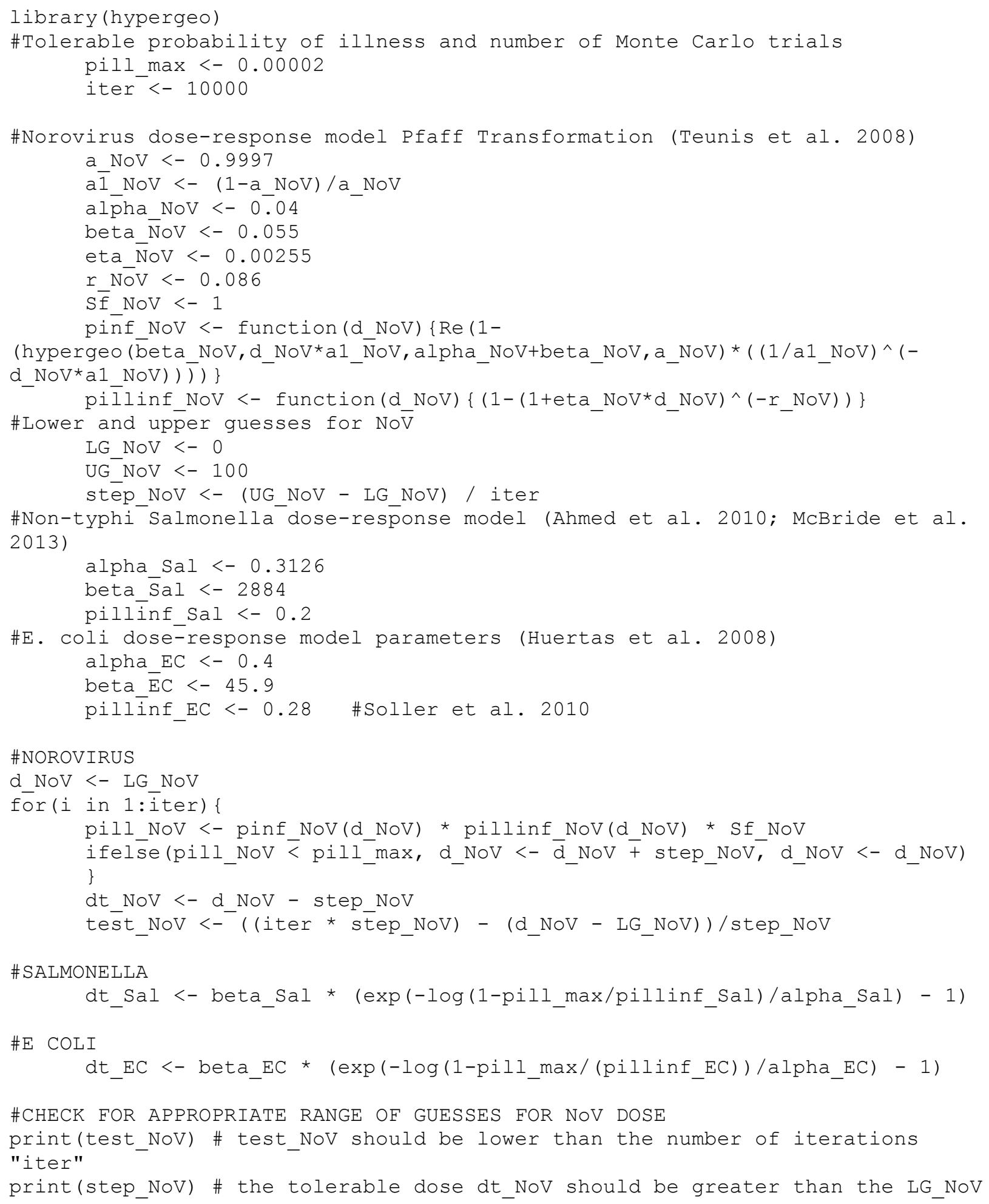


\#TOLERABLE DOSES

print (dt_NoV) \#NOROVIRUS tolerable dose

print (dt_Sal) \#SALMONELLA tolerable dose

print (dt_EC) \#E. COLI 0157:H7 tolerable dose 


\section{REFERENCES}

Ahmed W, Vieritz A, Goonetilleke A, Gardner T. Health risk from the use of roof-harvested rainwater in Southeast Queensland, Australia, as potable or nonpotable water, determined using quantitative microbial risk assessment. Appl Environ Microbiol 2010; 76: 7382 7391.

Amundsen TJ, Zastrow DJ, Wagner AL. Coagulation and Ultrafiltration of High-Alkalinity Greywater. AlchE Annual Meeting, San Francisco, CA, USA, 2013.

Becker WC, Wattier K. Surrogate parameters for monitoring organic matter and THM precursors. J Am Water Works Ass 1985; 77: 122-32.

Black S, Thurston JA, Gerba CP. Determination of $\mathrm{Ct}$ values for chlorine of resistant enteroviruses. J Environ Sci Heal A 2009; 44: 336-339.

Blyth W, Bradley R, Bunn D, Clarke C, Wilson T, Yang M. Investment risks under uncertain climate change policy. Energy policy 2007; 35: 5766-5773.

British Standards Institutions. Greywater systems - code of practice. Series/doc. No. BS 8525$1: 2010$.

Burrows, W. D., Schmidt, M. O., Carnevale, R. M., \& Schaub, S. A. Nonpotable reuse: Development of health criteria and technologies for shower water recycle. Water Science \& Technology 1991; 24(9), 81-88.

De la Rubia Á., Rodríguez M., León V.M, Prats D. Removal of natural organic matter and THM formation potential by ultra- and nanofiltration of surface water. Water Res 2008; 42(3), 714722.

Du Pisani, P. L. Direct reclamation of potable water at Windhoek's Goreangab reclamation plant. Desalination 2006; 188(1), 79-88.

Eisel W, Linton R, Muriana P. A survey of microbial levels for incoming raw beef, environmental sources, and ground beef in a red meat processing plant. Food Microbiol 1997; 14: 273-282.

Engelbrecht RS. A review of the US Army Construction Engineering Research Laboratory Program for recycling and reuse of laundry and shower wastewater: National Academies 1986.

Eriksson, E., Auffarth, K., Henze, M., \& Ledin, A. Characteristics of grey wastewater. Urban water 2002; 4(1), 85-104. 
Fiona Barker S, O'Toole J, Sinclair MI, Leder K, Malawaraarachchi M, Hamilton AJ. A probabilistic model of norovirus disease burden associated with greywater irrigation of homeproduced lettuce in Melbourne, Australia. Water Res 2013; 47: 1421-1432.

Florentin, A., Hautemanière, A., \& Hartemann, P. Health effects of disinfection by-products in chlorinated swimming pools. International journal of hygiene and environmental health $2011 ; 214(6)$ : 461-469.

Friedler E. Quality of individual domestic greywater streams and its implication for on-site treatment and reuse possibilities. Environ Technol 2004; 25: 997-1008.

FSIS. Risk Assessment of the Public Health Impact of Escherichia coli O157 : H7 in Ground Beef. http://www.fsis.usda.gov/OPPDE/rdad/FRPubs/00-023N/00-023NReport.pdf (Accessed 10/12/14). 2001.

Glenn RT. Regulatory Issues Associated with Greywater Reuse. Department of Civil and Environmental Engineering. M.S. Colorado State University 2012.

Goodgame R. Norovirus gastroenteritis. Curr Infect Dis Rep 2007; 9: 102-109.

Haas CN, Rose JB, Gerba CP. Quantitative microbial risk assessment: John Wiley \& Sons, 2014.

Hagen K. Removal of particles, bacteria and parasites with ultrafiltration for drinking water treatment. Desalination 1998; 119: 85-91.

Hamlyn-Harris, D.Review of health issues associated with potable reuse of wastewater. Final report for Department of Health and Age Care Australia, 2001.

Hankin RK, Lee A. A New Family of Non-Negative Distributions. Australian \& New Zeal J Stat 2006; 48: 67-78.

Jacangelo JG, Aieta EM, Carns KE, Cummings EW, Mallevialle J. Assessing Hollow-Fiber Ultrafiltration for Participate Removal. J Am Water Works Ass 1989: 68-75.

Johansson E, Wernersson ES, Hakanson H. Effects on the survival of Enterococcus faecium in dishwater. Foodserv Res Int 2004;15(3-4): 118-128.

Jumpatong K, Buddhasukh D. Electrocoagulation of some heavy metals. Chiang Mai J Sci 2003; 30: 33-40.

Kabsch-Korbutowicz M. Application of ultrafiltration integrated with coagulation for improved NOM removal. Desalination 2005; 174: 13-22. 
Kim, H., Shim, J., \& Lee, S. Formation of disinfection by-products in chlorinated swimming pool water Chemosphere 2002; 46(1): 123-130.

Lai K-Y. Liquid detergents, CRC Press. 2012.

LaKind, J. S., Richardson, S. D., \& Blount, B. C. The good, the bad, and the volatile: can we have both healthy pools and healthy people?. Environmental Science \& Technology 2010; 44(9), 3205-3210.

Lazarova V, Hills S, Birks R. Using recycled water for non-potable, urban uses: a review with particular reference to toilet flushing. Water Sci Technol Water Supply 2003; 3: 69-77.

Le Pendu J, Ruvoën-Clouet N, Kindberg E, Svensson L. Mendelian resistance to human norovirus infections. Semin Immunol 2006; 18:375-386.

Lee J, Cartwright R, Grueser T, Pascall MA. Efficiency of manual dishwashing conditions on bacterial survival on eating utensils. J Food Engineering 2007; 80: 885-891.

Li F, Wichmann K, Otterpohl R. Review of the technological approaches for grey water treatment and reuses. Sci Total Environ 2009; 407: 3439-3449.

Lu W, Leung AYT. A preliminary study on potential of developing shower/laundry wastewater reclamation and reuse system. Chemosphere 2003; 52: 1451-1459.

Macler BA, Regli S. Use of Microbial Risk Assessment in Setting U.S. Drinking Water Standards. Washington, D.C., U.S.A. 1992

Mara DD, Hamilton AJ, Sleigh PA. Karavarsamis, N. Options for Updating the 2006 WHO Guidelines: More Appropriate Tolerable Additional Burden of Disease, Improved Determination of Annual Risks, Norovirus and Ascaris Infection Risks, Extended Health-Protection Control Measures, Treatment and Non-treatment Options. World Health Organization, Geneva; 2010.

Mok H-F, Barker SF, Hamilton AJ. A probabilistic quantitative microbial risk assessment model of norovirus disease burden from wastewater irrigation of vegetables in Shepparton, Australia. Water Res 2014; 54: 347-362.

Mollah MY, Morkovsky P, Gomes JA, Kesmez M, Parga J, Cocke DL. Fundamentals, present and future perspectives of electrocoagulation. J Hazard Mater 2004; 114: 199-210.

Munro NB, Travis CC. Drinking-water standards: Risks for chemicals and radionuclides. Environmental Science \& Technology 1986; 20(8): 768-769.

Najm, I. N., Patania, N. L., Jacangelo, J. G., \& Krasner, S. W. Evaluating surrogates for disinfection by-products. Journal of the American Water Works Association 1994; 86(6): 
Natick Soldier Center. Portable System for Field-feeding Greywater Remediation and Recycling: Final Report 2007; SI-0310

NSF. NSF 350-1 Onsite residential and commercial greywater treatment systems for subsurface discharge. 2010.

Nolde E. Greywater reuse systems for toilet flushing in multi-storey buildings-over ten years experience in Berlin. Urban Water J 2000; 1: 275-284.

Oron, G., Adel, M., Agmon, V., Friedler, E., Halperin, R., Leshem, E., \& Weinberg, D. Greywater use in Israel and worldwide: Standards and prospects. Water research 2014; 58, 92-

Ottoson J, Stenström TA. Faecal contamination of greywater and associated microbial risks. Water Res. 2003; 37: 645-55.

Pidou, M., Memon, F. A., Stephenson, T., Jefferson, B., \& Jeffrey, P. Greywater recycling: treatment options and applications. Proceedings of the ICE-Engineering Sustainability 2007; 160(3): 119-131.

Pifer AD, Fairey JL. Suitability of organic matter surrogates to predict trihalomethane formation in drinking water sources. Environ Eng Sci 2014; 31: 117-126.

Potter BB, Wimsatt JC. USEPA method 415.3: Quantifying TOC, DOC, and SUVA. J Am Water Works Ass 2012; 104.

Reckhow DA, Singer PC, Malcolm RL. Chlorination of humic materials: byproduct formation and chemical interpretations. Environ Sci Technol 1990; 24: 1655-1664.

Riddle MS, Sanders JW, Putnam SD, Tribble DR. Incidence, etiology, and impact of diarrhea among long-term travelers (U.S. military and similar populations): A systematic review. Am J Trop Med Hyg 2006; 74(5): 891-900.

Radcliffe, J. C. Evolution of water recycling in Australian cities since 2003. Water science and technology: a journal of the International Association on Water Pollution Research 2010; 62(4): 792

Rule, K. L., Ebbett, V. R., \& Vikesland, P. J. Formation of chloroform and chlorinated organics by free-chlorine-mediated oxidation of triclosan. Environmental science \& technology 2010; 39(9): 3176-3185.

Salgot M, Huertas E, Weber S, Dott W, Hollender J. Wastewater reuse and risk: definition of key objectives. Desalination 2006; 187: 29-40. 
Schneider L. Greywater Reuse in Washington State. Rule Development Committee Issue Research Report. Washington State Department of Health. Wastewater Management Program. 2009; 16

Scholze RJ, Page M. Graywater Use by the Army--Is It Time Yet? DTIC Document, 2011.

Sheikh B. White Paper on Greywater. American Water Works Association. WateReuse Association, San Francisco, CA, 2010.

Soller JA, Bartrand T, Ashbolt NJ, Ravenscroft J, Wade TJ. Estimating the primary etiologic agents in recreational freshwaters impacted by human sources of faecal contamination. Water Res 2010; 44: 4736-4747.

Ståhl Wernersson E, Johansson E, Håkanson H. Cross-contamination in dishwashers. J Hosp Infect 2004; 56(4): 312-317.

Teunis P, Havelaar A. The Beta Poisson Dose-Response Model Is Not a Single-Hit Model. Risk Analysis 2000; 20: 513-520.

Teunis PF, Moe CL, Liu P, E Miller S, Lindesmith L, Baric RS, et al. Norwalk virus: how infectious is it? J Med Virol 2008; 80: 1468-1476.

The R Foundation for Statistical Computing: A Language and Environment for Statistical Computing (Version 3.1. 0). Vienna, Austria: R Foundation for Statistical Computing, 2014.

Thorven M, Grahn A, Hedlund K-O, Johansson H, Wahlfrid C, Larson G, et al. A homozygous nonsense mutation $(428 \mathrm{G} \rightarrow \mathrm{A})$ in the human secretor $(\mathrm{FUT} 2)$ gene provides resistance to symptomatic norovirus (GGII) infections. J Virol 2005; 79: 15351-15355.

Tripathi, S. K., Tyagi, R., \& Nandi, B. K. Removal of Residual Surfactants from Laundry Wastewater: A Review. Journal of Dispersion Science and Technology 2013; 34(11): 15261534.

US Army, Navy, and Air Force. TB MED 577: Sanitary Control and Surveillance of Field Water Supplies. Washington D.C. 2010.

USAPHC. Non-Potable Water Substitution and Reuse in the Field, Technical Information Paper 32-002-0111. U.S. Army Public Health Command (USAPHC), 2011.

USEPA. Exposure Factors Handbook. Washington, D.C. 2011; EPA/600/R-090/052F

USEPA. Guidelines for Water Reuse. Washington, D.C. 2012; EPA/600/R-12/618 
USEPA. Quantitative Microbial Risk Assessment to Estimate Illness in Freshwater Impacted by Agricultural Animal Sources of Fecal Contamination, Washington, D.C., 2010; EPA/822/R-10005

Uyguner-Demirel C, Bekbolet M. Significance of analytical parameters for the understanding of natural organic matter in relation to photocatalytic oxidation. Chemosphere 2011; 84: 10091031.

Villanueva, Cristina M., et al. "Bladder cancer and exposure to water disinfection by-products through ingestion, bathing, showering, and swimming in pools." American journal of epidemiology, 2007

Weisel, Clifford P., et al. "Childhood asthma and environmental exposures at swimming pools: state of the science and research recommendations."Environmental health perspectives 117.4 (2009): 500-507.

Westrell T, Bergstedt O, Stenström T, Ashbolt N. A theoretical approach to assess microbial risks due to failures in drinking water systems. Int J Environ Health Res 2003; 13: 181-197.

WHO. WHO Guidelines for the Safe Use of Wasterwater Excreta and Greywater. Vol 3: World Health Organization, 2006. 